\title{
LA POÉTICA DE LAS RUINAS EN EL SIGLO DE ORO ${ }^{1}$
}

\author{
JOSÉ LARA GARRIDO \\ Universidad de Málaga
}

Recepción: 3 de octubre de 2019 Aceptación: 3 de junio de 2020

Resumen: Tras reconsiderar en contraste varias reflexiones generales - tanto clásicas como actuales - sobre el significado de las ruinas, se establece la necesidad de elaborar paradigmas explicativos sobre las diferentes etapas históricas y series poemáticas. Partiendo de la amplitud semántica del término en español, el recurso crítico a una abundante bibliografía de alcance internacional, y privilegiando la aparecida en las últimas décadas, así como el aporte de nuevos textos poéticos y de diversos géneros hasta ahora no considerados, permite ordenar y disponer de un organigrama histórico y exegético diferente. Articulando los datos referidos a distintas tradiciones y tópicos, se determinan de manera precisa tanto los segmentos históricos como las inflexiones autoriales, elaborando una sucesión de paradigmas, que ponen de relieve determinados vacíos textuales, en autores y obras de relevancia no siempre atendidos. El estudio se prolonga con los cambios de todo orden que supuso el siglo XVIII, desde la visión diferente de Roma, la presencia de las ruinas artificiales en el jardín inglés, los libros de viajes y la aparición de la arqueología moderna, tras el impacto que supusieron, entre otros, los descubrimientos de Pompeya y Herculano.

${ }^{1}$ A propósito de A. Sánchez Jiménez y D. Crivellari (eds.), La poesía de ruinas en el Siglo de Oro, prólogo de Luis Alberto de Cuenca, Visor, Madrid, 2019, 287 pp. Trabajo adscrito al Grupo de Investigación «Andalucía Literaria y Crítica: textos inéditos y relecciones» (PAIDI HUM-233).

AnMal, XLI, 2020, pp. 9-117. 
Palabras clave: reflexiones generales sobre las ruinas, poéticas históricas, constituyentes modélicos, géneros, diacronía y variación de modelos, autores.

\begin{abstract}
This article opens with some general reflections (both classical and contemporary) on the meaning of ruins, and then it addresses the need to devise explanatory paradigms about the different historical periods and poetical sequences. The article takes as its starting point the broad meaning of the concept in Spanish, together with the extensive bibliography existing in the international context, and it favours those studies published in the last decades, as well as those poetical texts and genres unexplored so far. By doing so, the article makes it possible to offer a different historical and exegetical organigram. Examining the data about different traditions and topoi, the article demarcates both the historical sections and the authorial inflections, and it provides a series of paradigms that reveal certain textual gaps in relevant writers and works that have been paid scant attention. The article also explores the far-reaching changes operating in the eighteenth century, including the new view of Rome, the presence of artificial ruins in the English garden, travel books, and the beginning of modern archaeology, resulting from the discoveries of Pompeii and Herculaneum.
\end{abstract}

Keywords: general reflections on ruins, historical poetics, integrating models, genres, diachronic changes of models, authors.

1. «La singularidad (la individuación gracias al espacio, al tiempo y a la separación de las conciencias), a pesar de no tener cabida en la historia que escribe el historiador es el origen de toda la poesía que encierra este oficio [...]. Sabemos la emoción que provoca un texto o un objeto antiguos no porque sean bellos, sino porque proceden de un tiempo ya ido y porque su presencia es tan extraordinaria como la de un aerolito ${ }^{2}$. Nos es también conocida la emoción

\footnotetext{
2 En un documentadísimo estudio, que explora el campo semántico del término «ruina» en 19 lenguas (indoeuropeas y no indoeuropeas), A. Sulmajster Celmkier (2013: 181-182 y 189-190) analiza lo que denomina «les spectres large et etroit de ruine», partiendo del hecho de que «le concept se presente soit comme le même ensemble, soit encore comme ensemble separé, avec ou nom un lieu de causalité» y clasificando en grupos homogéneos las formas en que «les langues du monde, opérant un découpage différent du réel, certaines acceptions s'avèrent extensives, d'autres restrictives». Las polaridades de negativo y positivo le permiten asegurar cómo solo dos lenguas dedican una sola palabra a la ruina, diez extienden ese sentido a lo humano (entre ellos el latín y el español) y solo tres «appréhendrent le concept selon un tres large empan, allant jusqu'à un haut degré d'abtractio» (italiano, francés e inglés). Por otra parte, el estudio de las ruinas cuenta con hondos, originales y bien documentados ensayos de tipo general, entre
} 
que provocan los estudios de geografía histórica, donde la poesía del tiempo se superpone a la del espacio. Al asombro que produce la existencia del lugar se añade el asombro por el topónimo [...]. A esto se une la idea de que este mismo lugar que está aquí fue antaño otra cosa, siendo en aquel momento el mismo lugar que ahora vemos aquí: murallas de Marsella asediadas por César; antigua carretera por donde pasaron los muertos que seguía el mismo camino de la que hoy tenemos bajo nuestros pies [...]. La historia ocupa, pues, una posición gnoseológica intermedia entre la universalidad científica y la singularidad inefable» (Veyne, 1984: 49)3.

2. «El tema de las ruinas es muy respetable tema, sobre el cual el Renacimiento hará muy nobles poemas. Lope lo ha de tratar de mil modos en su juventud romántica, cuando la contemplación de las de Sagunto le hará parar mientes en sus propios destinos. Pero este tema es otra cosa en manos de Góngora, contemplador irónico del castillo de San Cervantes, frente a Toledo. Después de estas cosas, cuando observamos que lo venerable otrora puede ser motivo de ironía, podemos pensar que el tema está exhausto. Años más tarde, Caro escribirá su clásica elegía a las ruinas de Itálica, poema que a nadie se le ocurriría incluir en una historia de la poesía barroca si no fuera por estas razones de correlación e interdependencia. Ya no podemos hablar tanto de poemas barrocos en sí mismos cuanto de poemas de la edad barroca, fatalmente didácticos. Tesis o antítesis. No hay escape» ${ }^{4}$ (Montesinos, 1997: 24).

los que destaco los de J. Simmel (1934), R. Macaulay (1953), P. Zucker (1968), R. Mortier (1974), el comentario, centrado en Francia, del ensayo de I. G. Daemrich (1972), el colectivo sobre las ruinas romanas cordinado por V. De Caprio (1987) o los de M. Makarius (2004), A. Huis (2016) y N. Dacos (2016).

${ }^{3}$ De ahí la extrañeza y la sensación de inerte totum revolutum que producen seriaciones que conglomeran elementos de la temporalidad varia del motivo de las ruinas. Valga como ejemplo la conclusión que cierra el desenfocado itinerario de M. I. López Martínez (2009: 236): «Poco a poco se van consolidando los formantes que la definirán en los niveles estructurales y léxicosemánticos: el apóstrofe a las ruinas; la descriptio de los vestigios en la que abundan los recursos de evidentia y las enumeraciones a veces ligadas por la anáfora; los contrastes temporales entre el pasado y el presente; las oposiciones léxicas del esplendor frente al vocabulario de la destrucción y la muerte; el uso de las ruinas como ejemplo para demostrar una tesis; la relación con otros lugares; tempus edax rerum ubi sunt?; la perduración de la palabra; la invención de una segunda persona («peregrino», «viajero») que supone la búsqueda de un receptor, de alguien a quien explicar y dirigir». Veáse, por el contrario, como modelos conceptuales, Giardina (1986) y AA. VV. (2005b).

${ }^{4}$ Ese sujeto paradójico actúa como el poder temporal que impide que las entidades naturales o culturales imaginarias se queden gelée en su estéril llanura. Determinada masa de entidades naturales o culturales, adquieren en un súbito inmensas resonancias. Entidades como [...] las ruinas $[\ldots]$ adquieren en un espacio contrapunteado por la imago y el sujeto metafórico nueva vida, como la planta o el espacio dominado [...]. La fuerza de urdimbre y la gravitación 
3. «En las ruinas, como en la lengua - y toda ruina es, en cierto modo también una lengua y toda lengua, también, una ruina - nada reste vivante que dans la mesure où on la fait vivre [J. Vendryes]. Y el modo y manera de hacerlas vivir no es otro que el modo y manera en que se las hace funcionar'5. El Siglo de Oro — que las vio como topoi - las hizo funcionar como tema; el siglo XVIII superó su condición de tema para convertirlas en objeto de investigación. Las líneas que siguen intentan ser un ensayo hermenéutico que explique las diferencias ópticas explícitas e implícitas en ambas perspectivas, así como el muy vario tratamiento de un mismo objeto (Sagunto, sus ruinas) recibe en uno y otro motivo de visión, y que no solo hay que atribuir al género (el discurso poético / el discurso histórico) sino también, y en no poca medida, al cambio de sentido que las letras experimentan entre lo que se ha dado en llamar Siglo de Oro y lo que se ha dado en llamar Ilustración. En ambos casos - aun siendo uno y lo mismo lo leído- es, pero que muy otro, aquello que se lee. Y es muy otro porque - como dice Borges- una literatura difiere de otra anterior o ulterior, menos por el texto que por la manera de ser leída. Y es esa manera de ser leída la que permite reconstruir el modo de ser de ese lector, pues como indica Mortier (1974: 43) «ce qui importe est moins le regard que l'esprit dont il émane» (Siles, 1991: 7-8).

4. «Etiam periere ruinae dijo Lucano al contarnos en su Farsalia (Ix, 969) la visita de Julio César a las ruinas de Ilión. Cada día se hace de noche "y hasta

caracterizan ese espacio contrapunteado por la imago, que le presta la extensión, hasta donde ese espacio tiene fuerza animista en relación con otras entidades» (Lezama Lima, 1969: 15-16).

${ }^{5}$ Es frecuente la aplicación mecánica, sin más, de los textos de una época a otra. Se han llegado a entender como antecedentes clásicos poemas de la Antigüedad donde el espacio temporal opone la negatividad previa a una magnificación actual, proyectando ese contraste a las ruinas del XVI y XVII, concluyendo, como parece obvio, que el modelo se ha invertido. Así el topos recurrente en la poesía clásica desde la época de Augusto donde «los latinos presentan edificaciones que se alzan fastuosas donde antes campeaba libre la naturaleza», mientras que en los Siglos de Oro sucede lo contrario. Es erróneo en este sentido plantear que la Silva III de Estacio o algunos epigramas de Marcial presentan una fórmula cuyo «significado invertido constituye uno de los puntos de apoyo del tipificado canto a las ruinas que se expande en la Edad Moderna» (López Martínez, 2009: 229-230). En los autores romanos se trataría de dar constancia no de una pérdida sino de un programa concebido como renovatio. Se refieren a destrucciones calculadas en las que se observa «en géneral une tendance à reconstruire dans les plus grand dimensions [...] selon un plan architextural different [...]. Une valeur esthétique ou poétique des ruines n'est pas encore discernable à cette époque, c'est le fait de détruire et l'image du détruit qui donne aux ruines leur caractère détangeant [...]. L'empereur Auguste arrive par la suite, de manière très habile, à bàtir sur le ruines de la Republique en y construisant son programme politique de renouveau religieux» (Kaderka, 2013: 33-40); también sin olvidar los clásicos de N. Dacos sobre la Domus Aurea (1969) o las generales reflexiones cargadas de sugerencias de J. C. D'Amico-A. Testino Zaphiropaulus (2012) y M. Papini (2011) entre la relación sobre la ciudad sepultada y las ruinas. 
las ruinas perecieron. No quedaba ya entonces ni rastro de la fuerte muralla que contempló la despedida entre Héctor y Andrómaca" (veáse M. Papini, 2009: 89-111). Todavía no había nacido Schliemann y, por lo tanto, nadie sabía si aquellas ruinas visitadas por César eran las de la Troya homérica o las de cualquier otra ciudad venida a menos con el paso del tiempo [... $]^{6}$. Soñar con las ruinas arquitectónicas del pasado, como hicieron los humanistas del Renacimiento es una obligación de cualquier persona sensible [...]. No resulta difícil acercarse al mundo de las ruinas y a la fascinación que ha ejercido ese mundo en los intelectuales de occidente a partir del Humanismo del Cuatrocientos7. Y digo a partir del XV porque en la Antigüedad y en la Edad Media

\footnotetext{
${ }^{6}$ Como sintetiza K. Kaderka (2013: 10): «Le gout des ruines émerge en Europe avec la Renaissance. Les ruines antiques éveillent alors admiration en tant que symboles d'un passé glorieux et offrent une source d'inspiration aux humanistes et aux artistes. Elles suscitent également la volonté de comprendre le passé et favorisent la prise de conscience de la caducité des choses humaines. Si le goût des ruines demeure ensuite vivace, c'est à l'epoque des Lumières qu'il se transforme en véritable culte et fait aussi voir le jour à une science. La volonté de sauvegarder les vestiges chargés d'histoire de l'Antiquité, fascinants et irremplaçables, encouragera la systématisation des fouilles et donnera même naissance, avec l'oeuvre de J. J. Winckelmann, à la discipline archéologique. C'est pourtant qu'au cours du dernier siècle que se définit un intéret proprement scientifique pour les ruines». Ambos continentes de sentido aparecen, respectivamente, caracterizados por las monografías de S. Forero Mendoza (2002) y S. Lacroix (2007), además del colectivo dedicado a Atenas y la Magna Grecia (AA. VV., 2007). Pero veáse, además, contrastivamente, la lectura de R. Cacho Casal (2012: 185-186) acerca de que «las ruinas de Roma eran como las páginas de un manuscrito estragado que debían enmendar y editar».

7 «La ruina es acogida en la episteme clásica con más resignación que consuelo, siendo interiorizada más como una degradación o privación de la forma artística que como su afirmación [...]. Por encima de las contaminaciones morales, la ruina no podía ser reconocida por la estética clásica a no ser desde la transgresión, desde lo inacabado y lo fragmentario, desde un retorno de lo reprimido que no es sino la propia matriz de su condición anticlásica. No debe sorprender, pues, la carencia de una estética de la ruina en la doctrina clásica, como tampoco que florezca con lozanía apenas esta comienza a marchitarse. A este respecto las ruinas configuran vetas a través de las cuales se filtra la propia disolución del clasicismo [...]. Ante la contemplación de las ruinas el sentir clásico no puede por menos que verse afectado por el hecho de que las partes percibidas, presentes, invocan y reclaman a las ausentes. Casi de un modo instintivo tiende a restaurarlas, pero no solo ni tanto para evitar su destrucción cuanto para consumar su ideal de perfección» (Marchán Fiz, 1985: 5-6). Véanse las amplias panorámicas de F. Ferranti (2005) y el colectivo Représentation et esthétique des ruines (AA. VV., 2008), M. Papini (2009 y 2011) y J. Cl. Maire Vigueur (2010). En su muy personal y honda lectura de las ruinas en Quevedo, R. Cacho Casal recurría, siguiendo a Lavin (1992: 291-317), al imaginario renacentista «que reconoció en Roma uno de los más grandes archivos de la tradición. Sin embargo, sus ruinas servían también para recordar que muchos tesoros del mundo clásico se habían perdido definitivamente, que las humanae litterae habían sido consumidas por el peso de los siglos. La memoria histórica tenia fisuras y grietas, pero no todas eran irreparables. Los humanistas dedicaron sus esfuerzos a recuperar el legado grecorromano por medio de un ambicioso proyecto de estudio y reconstrucción de los vínculos que los unía a la Antigüedad [...]. Desde este punto de vista, la memoria y la creatividad están estrechamente relacionadas, pues el acto
} 
no existía ese particular embrujo que lo desmoronado, lo derrotado, lo inconcluso ejerce en nuestros ánimos produciéndonos una auténtica conmoción estética, derivada de nuestra propia condición ruinosa. Lleno de estas imágenes he releído con fruición la canción A las ruinas de Itálica de Rodrigo Caro, paradigma de cuantos poemas de este género se han compuesto en lengua castellana $[. .$.$] . En esa canción se contiene, exquisitamente rimada, toda la$ amargura del hombre al contemplar el «despedazado anfiteatro» de lo que un día no fue ruina, sino «esplendor intacto con voluntad de permanencia» (Cuenca, 2019: 11-15).

$* * *$

\section{II}

A la abundante y acreditada bibliografía sobre el motivo de las ruinas en la poesía española del Siglo de Oro $^{8}$ viene a unirse ahora el cuidadoso y

de recuperar se entiende como una renovación. Este dualismo alimenta los mayores logros del Renacimiento y puede también servir para explicar algunas de sus paradojas» (Cacho Casal, 2012: 185-186). También del mismo (2009, passim), y secundariamente lo ya apuntado en sentido general por A. Rey Álvarez (1997: 189-211), E. Molina (2005: 47-65) y M. Ferri Coll (2010: 525544). Pero véase también ahora lo indicado sobre el concepto de «reflexión» y su carácter, en diversos planos, de «cualidad discursiva», por D. Carrillo Morell (2019: 71-85).

${ }^{8}$ En relación con lo apuntado en la nota 2 quiero aducir que el mejor ejemplo enumerativo del contenido por la semántica de «ruinas» en español, lo encuentro en un anónimo poema de las Rimas del Incógnito. Nunca ha sido citado en la bibliografía sobre el motivo, a pesar de constituir el más acabado inventario de términos que expresan la fisicidad material exigida por una poética de la presencia que concentra todos los estratos de naturaleza y cultura (monumentos celebrativos, arquitectural civil y militar...): «Coliseos, pirámides, memorias, / simulacros, filabres, obeliscos, / pináculos, altares, grutas, riscos, / termas, efigies, láminas, historias, /lauros, trofeos, vencimientos, glorias, / sierras, pizarras, mármoles, pedriscos, / rocas, peñascos, cóncavos, mariscos, / bandos, guerras, traiciones y vitorias, / terraplenos, murallas, galerías, / casamatas, mauséolos, colosos, / torreones, sepulcros, monumentos, / fronteras, fuerte bronce, artillerías, / chapiteles, lumbreras, contrafosos, / arbotantes, sillares y cimientos, / sus firmes fundamentos, / el Tiempo, que los hace, / los muda, trueca, quita y los deshace» (FoulchéDelbosc, 1916: 359-360). También como muestra glosada de un conocido estribillo (gracias a Góngora) véase la letrilla siguiente:

«Aprender, flores, de mi / lo que va de ayer a hoy, / que ayer maravilla fui / y hoy sombra mía aun no soy». Glosa: Flores, si estáis presumidas / de esa vanidad de hermosas / ved que el riesgo es ser dichosas / y el bien temerlo entendidas. / En las fábricas caídas/ de aquel gusto en que me vi, / flores, lo estáis viendo así, / y así, por bien de los dos, / ya que no aprendí de vos, / aprended flores de mí. / No os ciegue la luz que os da / vuestra gala y vuestro aliento, / pues cuanto hoy es lucimiento / mañana eclipse será. / Mi gusto ayer visteis ya, / hoy bien veis cuan triste estoy, / tened, pues, ser lo que soy, / dejad esa pompa vana, / que ha de ir de hoy a mañana / lo que va de ayer a hoy. / Si lo que fuisteis perdéis / en eso que siendo dais / ¿cómo no siendo pensáis / que maravilla seréis? / ¿Cuál pirámide no veis / cuál muro o torre que hay / no os diga 
hondamente original volumen reunido por A. Sánchez Jiménez y D. Crivellari, cuya lectura me ha motivado a reflexionar de nuevo sobre lo que denominé hace años «poética de las ruinas», expresión que, con similar alcance, reaparece alguna que otra vez en esta colectánea. «Paradójico símbolo de la modernidad», la actualización efectiva que en páginas enriquecedoras se realizan sobre las reflexiones que han antecedido al volumen "así como de las reflexiones igualmente clásicas pero referentes al sentimiento que evocan las ruinas en general», podrían sintetizarse en un «nuevo sentimiento» con cuatro características reducibles a formas de «proyección radical del sujeto y su punto de vista sobre el paisaje»:

1. Un nuevo encuadre que aparece en la Italia renacentista «probablemente gracias a la óptica exotizante de los pintores y humanistas extranjeros [...] que identificaron en un paisaje obviamente cotidiano para los italianos ${ }^{9}$ un elemento especial que consideraron pintoresco y libresco: los vestigia de la Antigüedad que eran parte de la visión convencional de Italia que ellos proponían».

2. Estos vestigios arquitectónicos «primero fueron romanos, pero luego van a ser locales (Sagunto, Itálica, Mérida) e incluso de procedencia más moderna».

3. Las ruinas son en gran parte «una creación del sujeto» que es «quien prepara con ellas un teatro marcado por signos escópicos que construyen un decorado para sus reflexiones incluso si los restos no son perceptibles [...]. A este carácter medio imaginario y fantasmagórico se le une un elemento clave: la conciencia histórica ${ }^{10}$. Y es que, a partir del Renacimiento, la ruina es un

en polvo por mí, / flores, quién dirá, pues hoy/ menos que ceniza soy / que ayer maravilla fui? / Fue Troya y de haber caído / campo y señas han quedado, / pero en mí de lo pasado / ni las sombras de haber sido. / Tanto el tiempo ha desmentido / lo que estuve y lo que estoy, / que espanto ayer, burla hoy, / halla todo el mundo en mí, / que aun ayer su sombra fui / y hoy sombra mía aun no soy» [A. B. P. G.] (Ms. 5507 de la BNE, ff. 121r-v).

Para los fundamentos fundacionales del concepto de ruina en un sentido histórico véase G. M. Della Fina (2009) y E. M. Orlin (2002).

${ }^{9}$ Como ya observó atinadamente J. Bialostocki (1973: 193): «Las ruinas fueron uno de los motivos principales relacionados con la idea de vanitas. Su expresión patética fue valorada con anterioridad en la poesía, sobre todo en relación con las ruinas romanas».

10 E. Orozco Díaz (1947: 122) ya subrayó «la relación vital y artística que se establece entre el poeta o pintor y unas ruinas o jardín concreto. Porque, como fundamento psicológico, interesa por sí este detenerse ante ambas realidades por una atracción en la que rara vez cuenta en el primero la curiosidad arqueológica [...]. Por esta parte precede a toda consideración o reflexión moralizadora, pues es claro que antes de deducir la enseñanza de la caducidad de la grandeza pasada [...] el poeta ha buscado la contemplación». R. Cacho Casal, que sitúa a Quevedo «al final de la tradición renacentista», ha detectado con sutileza crítica extraordinaria cómo «pese a compartir muchos de sus ideales, deja también entrever varios aspectos que son clara señal de una nueva época y una nueva estética. Sus poemas sobre Roma emplean a Du Bellay como fuente literaria y, asimismo, como intermediario que lo conduce a dialogar con otros autores clásicos. Sin embargo, su lectura de estos modelos responde también a la epistemología barroca 
asidero a un mundo desaparecido y diferente al moderno, a un mundo que los humanistas y pintores de ruinas pretenden reconstruir acumulando vestigios rotos y diversas antigüedades».

4. Las ruinas suponen igualmente «una meditación sobre el paso del tiempo sobre el ser humano, es decir, sobre la decadencia y la desaparición no solo a nivel de civilizaciones, sino de individuos: el tempus edax rerum se transforma en un tempus edax hominun. Será el carácter de la época y del artista que trate las ruinas el que otorgue a esta reflexión sobre la fragilidad de la vida un tono optimista o sombrío, tal vez más apropiado para la materia» (Sánchez Jiménez, 2019: 25) ${ }^{11}$.

La poética y la historicidad del motivo son, consecuentemente, conectables. No hay un significado absolutamente nítido y constante, como tampoco los referentes son inmodificables, por lo que cabe hacer un trayecto casi obligado que atienda a la formulación sucesiva de diversos paradigmas. El motivo de las ruinas es de una polivalencia discursiva que nos aleja de las generalizaciones como la conocida - y tanto tiempo aceptada - reflexión de G. Simmel. Para

y refleja el cambio de paradigma que comenzó a finales del siglo xvi. El escepticismo hacia la visión analógica de la realidad lleva a una separación ontológica entre las palabras (verba) y las cosas (res), que en el plano literario fomenta la proliferación de agudezas dentro de la esfera del conceptismo. El Barroco ya no puede ofrecer ideas originales a partir del estudio de la Antigüedad, sino nuevas formas de interpretar y reescribir la cultura clásica y humanística. El objetivo de Quevedo no es solo, como en el caso de Du Bellay, el de reconstruir y reordenar el pasado con los ojos del presente, sino también de aprovechar cada una de las ruinas verbales y arqueológicas como fragmentos independientes a partir de los cuales dar a luz cadenas de conceptos basados en oxímoros y cruces de metáforas» (2012: 190-191).

${ }^{11}$ Compárese esta esclarecedora elucidación con uno de tantos discursos confusos, resultado por otra parte de una aceptable antología temática de la poesía barroca: «La repentina afición de artistas y escritores por la arqueología concuerda con la necesidad de establecer referencias con respecto el presente: ello condujo al descubrimiento de las ruinas, único testimonio del tiempo. W. Benjamin piensa que la estima sentida en el siglo xvII por las ruinas responde a la admiración barroca hacia cualquier forma de apoteosis, en este caso como exaltación de la Nada. Los muros desnudos, los capiteles sin arco y los peldaños cubiertos de maleza sirvieron a los poetas para significar su propia degradación. Las ruinas son lo único que queda del tiempo y aun estas van a desaparecer (Lucano, 9, 969). Las de Itálica y Sagunto fueron una realidad cercana a los poetas españoles, y aun cuando desde Cartago, Troya y Roma supusieron una referencia sobre todo literaria, todas aportaron en su ideario ético un doble sentimiento: la nostalgia por la que el ser humano fuera capaz de edificar cuando estaba en libertad y la certeza de que el tiempo, y la Naturaleza también, arrasarán los escenarios de esta fábula [...]. Las ruinas que en el periodo romántico adquirirán un renovado interés, muestran una superposición de tiempos, una tensión entre lo horrible y lo bello, la paradoja que permite comprobar cómo la artificial se ha asimilado a lo natural. Son el decorado para representar el conflicto» (Andrés, I, 1994: 49-50). ¡Cómo cambia el panorama en otras latitudes cercanas a la nuestra! Véase el ejemplar artículo de R. Negri (1972: s. v.) o las magistrales síntesis de M. Makarius (2004) o de los ensayos reunidos en el colectivo Ruines, traces, empreintes (2009). 
este sociólogo de la cultura «el equilibrio característico entre la materia que pesa y resiste pasivamente a la presión y la espiritualidad formadora que tiende hacia lo alto», queda, empero, destruido en el mismo momento en que el edificio cae en ruinas. Esto no significa, en efecto, sino que las fuerzas puramente naturales «comienzan a enseñorearse de la obra del hombre, que, al fin, la exacta compensación entre la naturaleza y el espíritu — representada por el edificio - se ha roto a favor de la naturaleza. Este desplazamiento del fiel se resuelve en una tragedia cósmica que envuelve a nuestros ojos toda ruina en las sombras de la melancolía». En definitiva, un ciclo sempiterno en el cual «la naturaleza ha hecho de la obra de arte el material para su creación, de la misma manera que antes el arte se había servido de la naturaleza como materia para su obra». No deja de ser significativo que otras reflexiones menos hegelianas de Simmel y más propiciadoras, al tiempo, de una consideración del motivo en su espesor histórico, hayan sido orilladas, si se exceptúa la profundización hecha sobre el sentido de la melancolía en las ruinas. De especial relevancia es su apunte «sobre el carácter de pretérito que tienen las ruinas»: «Son las ruinas un lugar de vida de donde la vida se ha retirado, y esto no es solo algo negativo. No: ante la ruina se siente de modo inmediato, con la actualidad y rigor de lo presente, que la vida ha habitado aquí alguna vez con toda su opulencia y todas sus vicisitudes. La ruina es la forma actual de la vida pretérita, la forma presente del pasado, no por sus contenidos o residuos sino como tal pasado» (Simmel, 1934: 211-219) ${ }^{12}$. Igualmente resaltable -y

${ }^{12}$ De estas conclusiones últimas de Simmel como resultado de la dialéctica de tesis/antítesis partían las reflexiones sobre el motivo debidas a E. Orozco Díaz: «Es el deseo de percibir la vida, de estudiar la construcción, las formas de su arte, de gozar con sus restos, pero interesándole esa visión compleja de Naturaleza y Arte [...] y así lo que se ansía o gusta no es su fusión con el paisaje en una visión única, sino, precisamente, el aclarar lo artificial de la Naturaleza para incorporarlo íntegramente al mundo del Arte. No es el deleite de lo pintoresco resultante, sino el de las formas bellas de por sí que se consideran como ideales y perfectas» (1947: 128). Y pocas páginas antes abría el círculo hermenéutico, al considerar que «la belleza de las ruinas no reside en que sean un elemento del paisaje sino en esa sensación de que lo artificial, lo artístico, se incorpora a la Naturaleza. Ante ellas sentimos un proceso de tránsito, de asimilación que la Naturaleza realiza, convirtiendo lo artificial en material para su creación. Así, los poetas no solo perciben este tránsito, este reincorporarse de la materia a su primer origen sino que incluso lo destacan: "Lo que fuisteis sois, lloradas piedras", dice Equilache ante unas ruinas. Y López de Zárate pensará aún más la idea: "Son (lo que fueron) materiales rudos, a la primera forma reducidos"» (pp. 122-123). A más de ello, su síntesis conduce a la motivación de una originalidad en el hecho de que «nuestra poesía de ruinas, aunque formalmente enlace con lo final renacentista, tiene sus raíces en algo más trascendente que esa emoción de lo pintoresco y ese sentido de melancolía y nostalgia de la vida que pasó, que unido a la admiración por la Antigüedad constituyen las notas dominantes en la visión del tema que, en general, recogen las letras y la pintura fuera de España» (p. 130). El aliento europeo de este temprano panorama evoca lo que serán los profundos análisis recientes de M. McGovan (2000), S. Forero Mendoza (2002), S. Fabricio Costa (dir.) (2005: 69-104) o S. Lacroix (2007). 
reiterado- ha sido el ensayo de J. Starobinski «La mélancolie dans les ruines». La reflexión de Starobinski viene a invertir en su tesis central el concepto cíclico que encadena a naturaleza y arte, y en el que las ruinas vienen a ser un episódico epifenómeno, para establecer un principio de dialéctica histórica: las ruinas provocan siempre la búsqueda de un significado. Partiendo de Simmel, matiza que «se establece un equilibro en que las fuerzas antagónicas de la naturaleza y la cultura se reconcilian» para concluir con estas palabras que han de servir como pórtico al recorrido que emprendo, con un paralelaje de aportaciones propias a la reseña del volumen recién aparecido: «Las formas materiales que dan fe de lagrandeza de una edad, no han cedido completamente ante el desorden sin edad. Sobrevive la huella de un gran designio; pero la supervivencia más cierta es la que anuncian los musgos y la lozana maleza. Supervivencia de ruina es siempre un sueño ante la invasión del olvido [...]. El monumento antiguo era un memorial, una monición. Perpetuaba un recuerdo. Pero el recuerdo inicial se ha perdido; ahora le sucede una segunda significación, anunciando en adelante la desaparición del recuerdo que el constructor había pretendido perpetrar en la piedra. Su melancolía reside en el hecho de que se ha convertido en monumento de su significación perdida» (1964: 180).

Otro filósofo fascinado por las vastas sistematizaciones de la fenomenología hegeliana, E. Bloch, al reflexionar sobre el culto a las ruinas en el Barroco, intentó definir su sentido como producto de «la compenetración entre decadencia y apoteosis, de historia que fluye y mundo cercano al fin, expresada mediante cierta alegoría de lo efímero. En esta radical ambigüedad anidaría la belleza fúnebre de sensaciones que asumen un sentido edificante, al configurarse como meditación elegíaca sobre el destino del hombre y sobre las catástrofes del mundo» ${ }^{13}$. Tras recordar esta explicación que pese a su coherencia

13 Para una mediatización posible de lo que en 1950 expresó S. Freud en su clásico análisis de El malestar en la cultura al comparar la reminiscencia de la mente humana «con la ciudad de Roma y sus varios estratos arqueológicos», hay que notar, como ha hecho R. Cacho Casal, que Freud «tras describir algunas de las fases más importantes de la expansión histórica de la ciudad, deja correr su fantasía y se imagina una Roma en la que no hubiera "desaparecido nada de lo que alguna vez existió" y donde los espacios urbanos y los monumentos de épocas diversas coexistieran [...]. Sin embargo, termina renegando de esta utopía urbana, cuyo desarrollo, cree él, no puede llevar a otra cosa que a "a lo inconcebible y aun a lo absurdo". La mente no es como una ciudad, y solo en la primera perviven «todos los estadios previos, junto a la forma definitiva", pues "en la vida psíquica la conservación de lo pretérito es la regla"» (2012: 186187). «A propósito de cómo los hombres del XVII ven siempre la naturaleza - había escrito en palabras emblemáticas, que recoge Raimondi, W. Benjamin-, hay que afirmar que no lo hacen cuando está en su plenitud y en flor, sino en la madurez y decadencia de sus propias criaturas, como un paisaje de ruinas que cristalizan la historia en un emblema de melancolía metafísica» (pp. 51-52). De hecho, se ha llegado a establecer de forma muy precisa y contundente la correlación entre las variaciones del gusto por las ruinas y el sentido de imitación detectable en una conciencia histórica: «Ce qui revient à dire que toute pensée de l'Histoire repose sur una pensée 
interna no deja de constituir un tejido de axiomas reduccionistas de la riquísima complejidad evidenciable en el tratamiento del motivo, E. Raimondi ha propuesto como alternativa el ejercicio analítico, para acercarse a concretos compromisos mediante la comparación de texto a texto:

Il confronto [...] deve essere fatto non tanto per stabilire degli antecedenti genetici o distinguere due tecniche che si esercitano sul medesimo tema, quanto per mostrare como sia diverso l'attegiamento spirituale che è alla base delle due versioni.

Estudiando comparativamente el poema de Cesarini sobre Anzio (vetustissima Vulscorum urbs nunc dirupta) con su modelo, el de Sannazaro sobre las ruinas de Cumas, urbs vetustissima, evidencia cómo frente a la serie rústica de iuvenca, bulbucus, oves, armenta, el poeta del Seicento elabora su propia sigla en un paisaje escenográfico de pompa pictórica (theatrales horrenti clade ruina), cómo el nihilismo fatalista, que se confronta solo con la certeza de la catástrofe, es sustituido por una toma de posición contra la Fortuna y una aspiración a conocer los secretos de la naturaleza de tono casi lucreciano (1966: 42-72). La explicación de Raimondi, con conocimiento de la intratextualidad compleja del motivo, presupone una indagación ejemplar de cómo ciertos elementos novedosos de la estructura y sentido poemáticos comportan descubrimientos sobre la propia tradición. Así la «réverie-pellegrinaggio» revive un tema patético de la poesía clásica: el episodio de César que visita las ruinae de Troya en La Farsalia (IX, vv. 950-999)14. A la compulsiva búsqueda

de la ruine, que celle — ci soit formulée directement ou signifiée de façon plus médiate et métaphorique par les biais des propositions artistiques». La reflexión privilegiada de un W. Benjamin, en la novena de sus tesis sobre filosofía de la historia, es una violenta crítica a la ideología del progreso y la primera expresión categórica de un pensamiento sobre la catástrofe que se adelanta a las reflexiones de Adorno y Horkheimer. Pero antes, de Poggio Bracciolini a E. Gibbon, «il faut reconnaître dans les ruines un support privilégiée de meditation qui conduit à depasser leur presénce materielle pour les transformer en figures de la pensée». En W. Benjamin (cruce esencial del romanticismo alemán, el materialismo judío y el materialismo histórico) el «pensamiento poético» (H. Arendt) adquiere la contundencia de una alegoría, cuyas raíces remiten a Hegel y a su reelaboración de una metáfora de Schiller, y su fórmula del Ángel paradójico confirma una manifestación de irresistible contundencia, donde «la catastrophe ne constitue pas un évenement exterieur et insensé qui viendrait rompre le cours de l'Histoire, mais elle est étroitement solidarie du progrès car elle en constitue la raçon même» (Forero Mendoza, 2002: 151-159). También las acotaciones históricas de F. Lecocq (2005: 69-104), A. Vauchez (2006) y J. Cl. Marie Vigueur (2010).

14 Raimondi lo analiza poco antes en unos dísticos de Chiabrera en sus Carmina. Dentro de ellos se encuentra la historia de un joven aristocrático que se refugia en la campiña, en la soledad de una naturaleza amigable, con la esperanza de sobreponerse al mal que finalmente lo llevará a la muerte, reviviendo, entretanto un gran tema patético de la poesía clásica: el episodio de César que visita las ruinas de Troya y contempla entre las «putres trunci» y los «dumenta» el 
de un sentido «inmemorial» en las ruinas, legado del pensamiento romántico desde Schelling (Marchan Fiz, 1985: 12-13), sustituye, en consecuencia, la reconstrucción filológica de todo aquello que cada texto encierra de «signification perdue» (J. Starobinski). Todo lo contrario de lo que postula, con desafiante paradoja metacrítica, P. Spedicato desde la «persistenza delle rovine» y su actualidad «come elemento essenziale nella fruizione artistica e spectacolare»: «Un discorso più specifico sulle rovine della letteratura non può comportare una mera individuazione -rivisitazione dei suoi tópoi rintracciati in uno o più periodi della tradizione letteraria, ma piuttosto il considerare la letteratura un inmenso corpo rovinato essa stessa, un panorama fatto di rovine sovrapposte del tempo ruens (Orazio), rovinante e precipitante» (1986: 78-79).

La polivalencia discursiva de las ruinas ${ }^{15}$ es de una compleja y refinada materialización, mediatizadora de un espectro de significados tan divergentes como el filográfico o el didáctico (en la variedad de encuadres que abarcan desde lo ético-político a la meditatio mortis). Al tiempo, el motivo conjuga su adherencia o su distancia a modelos retóricos establecidos, inductores de

espectáculo majestuoso de una «veneranda vetustas». Además de los textos de Propercio (Elegías, IV, 4 y IV, 5) y el capítulo I del libro vi de las Naturales quaestiones de Séneca, E. Raimondi reclama la atención sobre un pasaje muy admirado del De constantia de J. Lipsio (Ofrezco su versión: «Es natural a todo lo criado que por una intrínseca potencia camina a la corrupción y a la muerte [...]. Los animales, la ciudad y los reinos portan en sí mismos su ruina [...]. Estos grandes cuerpos, a nuestro parecer eternos, están destinados a la muerte y a la transmutación [...] y así como cualquier hombre tiene su juventud, su virilidad, su vejez y su muerte, así les cumple a estos. Comienzan, crecen, duran, florecen y después de esto caen [...]. Los antiguos vieron y adornaron los cadáveres de Cartago, de Numancia y de Corinto; nosotros las vilísimas ruinas de Atenas, de Esparta y de tanta ilustre ciudad. Aquella misma señora del mundo y falsamente llamada eterna ¿dónde está? Arruinada, destruida, caída, terminó no con una sola muerte sus días y hoy que se va ambiciosamente buscando no se la encuentre en su propio y antiguo sitio»). Véase también F. Giardini (1994).

${ }^{15}$ Se puede producir también, evitando el carácter emblematizador y el cauce de formalismos retóricos muy marcados (desde las ruinas clásicas a las locales), una poética de la inconcreción. La ruina innominada adquiere la solidez y el poder de convicción de un predicado universal. Extensión que alcanza igualmente al destinatario de un discurso del desengaño que hace del indefinido referente el fundamento inconmovible de cualquier premisa irrefutable. La apertura al infinito del motivo bloquea así otras lecturas desde la subjetiva situación de una compositio loci. Un ejemplo en el que afloran todavía la grandeza de lo destruido (y su misma localización) junto al prodigio de los paradigmas clásicos es el siguiente soneto de Francisco Manuel de Melo: Ruinas de un edificio. «Este, joh Licio, que has visto sobre el viento / y de la tierra ves midiendo el llano, / ya silla del monarca lusitano, / ya cátedra moral del escarmiento, /como copia antes fue de un alto intento, / miedo es agora del discurso humano; / el bronce, el mármol se asegura en vano / contra el menor fatal acabamiento. / Para admirar prestaronle distinto / cuanto valor gozaron las edades / en Roma, Atenas, Menfis y Corinto; / para desengañar las soledades / en cada piedra, en término sucinto, / un fin, una memoria, unas verdades» $(1649$, f. $4 \mathrm{v})$. 
recursos retóricos y diseños estructurales fijados en ciertas cadenas modelizadoras, que se renuevan y mutan en el proceso histórico con lo que podría denominarse su apertura significacional. El término fue puesto en circulación por G. Cabello Porras a propósito de Fernando de Herrera, anotando cómo el paradigma clásico es seguido por el autor de las Anotaciones a partir de una óptica distanciadora tendente a diluirlo y modificarlo en diversas direcciones. Tal reconducción implica una primera variante en que las ruinas se contrastan con la eternización poética, una segunda que introduce «determinada res histórica en la poetización», una tercera en la que «el acudir a nuevas ruinas [...] configura un nuevo factor de la diferenciación herreriana»; finalmente, el tratamiento de Tartesos, con el que el divino «da un paso importante hacia la poetización de las ruinas acuáticas» (1981: 39-63) (clarificador análisis que, cuando no se trasvasa, es enturbiado en el endeble panorama de J. M. Ferri Coll). Frente a este proceder de hermenéutica diferenciadora han dominado categorizaciones de rígido dualismo. Por ejemplo, y es de destacar por su brillante redicción, en las rápidas pinceladas con que globaliza el sentido del descubrimiento de las ruinas R. Andrés ${ }^{16}$ y que, significativamente, se inician recurriendo a W. Benjamin: «Las de Itálica y Sagunto fueron una realidad cercana a los poetas españoles, y aun cuando las de Cartago, Troya y Roma supusieron una referencia sobre todo literaria, todas aportaron en su ideario ético un doble sentimiento: la nostalgia por lo que el ser humano fuera capaz de edificar cuando estaba en libertad y la certeza de que el tiempo y la Naturaleza también, arrasarán los escenarios de esta fábula [...]. Las ruinas que en el período romántico adquirirán un renovado interés, muestran una superposición de tiempos, una tensión entre lo horrible y lo bello, la paradoja que permite comprobar cómo lo artificial se ha asimilado a lo natural. Son el decorado para representar un conflicto» (1994: 49-50) ${ }^{17}$. Igualmente en el señalamiento de

16 Desproporcionada, por su exigüidad para el empeño perseguido en una antología presentada, es la sección que dedica a las ruinas en el volumen segundo (pp. 581-593), con la falta de textos esenciales de Góngora o Lope y de confimaciones complementarias con las series de Sagunto e Itálica. Tampoco parece ideada para abarcar el motivo la recopilación debida a S. B. Vranich (1981), que reúne solo treinta y seis composiciones (y las que da como inéditas estaban publicadas con anterioridad). Baste recordar que ya L. Pfandl consideraba la amplitud del motivo al considerar que la lírica barroca española «puede dividirse en cuatro grupos principales: primero, los homenajes de carácter panegirista y de mecenaje; segundo, la poesía de ruinas y desengaño, que corresponde al sentimiento desilusionista de la época; en tercer lugar la lírica amorosa y galante [...] finalmente, la poesía satírica y humanística» (1942: 510; también 538 y 541). Frente a tales generalizaciones resultan ejemplares, como muestra, los análisis concretos que sobre Quevedo han llevado a término, A. Martinengo (2009: 263-280), E. Moreno Castillo (2004: 501-543) y en particular R. Cacho Casal (2012: passim).

17 Ya me he referido y volveré a hacerlo más adelante a las tesis de W. Benjamin en su exacto encuadre. Pero en general la cuestión de los conformantes ideológicos de su teoría sobre la catástrofe, «qui se présente comme une violente critique de l'ideólogie du progrès», han sido 
modelos, se ha privilegiado un modo reduccionista donde la tendencia a categorizar en una sola función ha venido marcada por una cadena temática monocorde, en relación exclusiva casi siempre con Superbi colli, como ya enunciara tempranamente un R. Foulché Delbosc, concluyendo que «si Troie, Carthage, Roma, Sagonte, Italica, n'ont inspiré que des pensées sensiblement pareilles, cela tient, moins, semble-t-il, à l'identité des sujets qu'à ce fait que toute cette litterature est le décalque —ou parfois la paraphrase — d'un meme sonnet italien» (1904: 242).

Volviendo sobre los supuestos afianzados en E. Raimondi, la lectura histórica del motivo de las ruinas hace imprescindible ahondar en cómo se establecen sus variadas inflexiones internas en relación con los descubrimientos operados desde la tradición funcional, retórica y artística. La distinta trascendencia de los paradigmas inducidos por refracciones más o menos intensas de los modelos diversos (donde la lírica neolatina jugó un papel esencial) son en diverso grado perceptibles en la poesía de las ruinas del Siglo de Oro. Una poesía atravesada por procesos de derivación, mixtura y reinvención que no suponen ni el abandono sincrónico del paradigma clásico (Roma y Cartago) ni la integración de los grandes modelos, desde el Carmen metricum de Petrarca al Superbi colli, que acoge al mismo tiempo la perspectiva de una visión inmediata y próxima, generadora de una sentimentalidad que va más allá de lo meramente arqueológico o erudito ${ }^{18}$.

elucidados en un magistral ensayo de S. Forero Mendoza (Kaderka, 2013: esp. 152-156). Sobre el carácter fundacional de las ruinas de Roma, como ha recordado V. De Caprio (1987: 8), desde su «coerente tipologia discursiva» los modelos que en su interior se elaboran «si rivelano capaci di porsi come forme organizzative dell'immaginario letterario e particolarmente poetico, anche in aree tematiche a prima vista non direttamente connesse con la tradizione rovinistica su Roma: rovine di altre città, rovine come emblema o metafora dé luoghi dello spirito, tematica della distruzione e della catastrofe»».

${ }^{18}$ En su clásico estudio E. Orozco Díaz subrayó este sentido, al indicar que «las dos ruinas que con más frecuencia cantan nuestros poetas son las de Itálica y las de Sagunto. Ello demuestra cómo responden no a una influencia en abstracto del tema sino a una gustada contemplación, directa, de la realidad» (1947: 134). Esta visión próxima y concreta resultará en muchas ocasiones determinante, pues como ha señalado R. Mortier «ce qui importe en cette matière est moins l'objet en soi que le regard qui le frappe, et moins le regard que l'esprit dont il émane» (1974: 43). Es lo que muestra, por ejemplo, Ruiz Sánchez al analizar la representación proporcionada de la primitiva Roma y su herencia en poetas como Du Bellay. A la primera se le puede denominar elegiaca (Álvarez Hernández, 1982-1983: 34-45) y el recurso formal más eficiente deriva de contraponer la grandeza de la Roma imperial a sus humildes orígenes; en sus imitaciones adopta el modelo del locus horridus con la secuencia de signos (desde la agricultura que labra los campos que fueron la ciudad a las fieras que habitan los restos de las moradas humanas). Un punto de inflexión importante lo marca el De Veteris et novae Romae statu de J. Dorat. Se crea, en conjunto, un código emblemático donde «la combinación de las dos vertientes del modelo properciano, el clásico y el de la visión de las ruinas corresponde de forma natural a la 
Diversas dificultades de orden hermenéutico para esa lectura histórica fueron ya apuntadas sutilmente por B. López Bueno al considerar las conexiones posibles entre «tópica literaria y realización textual». Entre otras, la falta de «respuestas satisfactorias» para el «idóneo abordaje crítico de los textos literarios», y su corolario de que «algunos muy certeros análisis son imposibles de extrapolar desde su concreta realización a una consideración abstracta del proceso»; el que «cada acercamiento crítico a un texto es una experiencia distinta» con la paradójica consecuencia de que «el texto es virtualmente riquísimo» y que «cuanto más exhaustivo sea un esquema —al fin y al cabo siempre formalista - menos abiertas se dejan sus posibilidades»; el texto literario, «signo resultante de un proceso de formalización de sustancia, tanto de expresión como de contenido», permite operar «con un tipo de análisis retórico, estilístico, o como a bien tenga denominarse, a partir de una retórica normativa, o sintagmática, a través de la descripción de los elementos interrelacionados». Nos encontramos resueltamente con lo que podría calibrarse de «tópica» distinta al género, más amplia y «poligenérica» que cristaliza en «subgéneros» específicos (1986: 59-63). Hasta aquí todos podemos estar conformes, pero resulta menos convincente que el motivo de las ruinas puede ser, por cualquiera de esas sendas, una «presencia que se vehicula en formas recurrentes fácilmente identificables», máxime si se privilegia en la herencia de la «erudición positivista» la imitación que Cetina hizo del Superbi colli y donde «las claves significacionales ya están dadas: oposición entre un pasado glorioso y la destrucción presente»; la extrapolación del motivo para aplicación personal de consuelo [...]; para la exposición del motivo, la descriptio de los fragmenta arquitectónicos [...] y la explícita consolatio» (pp. 63-64). De una doble «fértil descendencia» el soneto cetiniano explicaría de una manera que a su entender es «la más segura y evidente» el doble camino de la aplicación filográfica cuajada de «sintagmas característicos [...] que pasarán en buena medida lexicalizados a las recreaciones sucesivas» y al afianzamiento definitivo del tópico, «encauzándolo, en la visión de la antigua ciudad cercana a Sevilla» y «en el seno de una poesía que reflexiona preocupadamente sobre la vida y que propone un código de comportamiento basado en el ejercicios de la virtus estoica» ${ }^{19}$.

temática de la circularidad. El modelo properciano, que contrastaba los humildes inicios de Roma con la grandeza presente es subvertido [...]. La combinación de ambas perspectivas, la properciana y su imitación en la temática de las ruinas del Renacimiento, daría lugar, en efecto, al trazado de un círculo perfecto» (2000: 85-88 y 91-112). En general, remitiré de una vez por todas al esencial y poco manejado ensayo de F. Gray sobre Du Bellay (1978). El mejor recorrido por la bibliografía al respecto es el clásico debido a M. Brady Wells (1974).

19 Dedico extensión particular a las ruinas de Itálica en torno a la esencial Canción de R. Caro. La obsesión arqueologizante llegará incluso a la indagación de unas ruinas inexistentes, como las troyanas. Sobre la realidad constatable de las ruinas troyanas se escribirá en plena 
efervescencia del motivo un Epitome de la historia de Troya, su fundación y ruina, con un discurso apologético en defesa de su verdad por don Cristóbal de Monroy y Silva (Sevilla, Francisco de Lyra, 1641). Como le indica en unos versos preliminares Melchor Ossorio «su íntimo amigo»: «A Troya hace Fénix vuestra pluma / pues estando en ceniza sepultada / cobra con vuestra historia nueva vida». Se trata de una disquisición erudita que acota incluso un «Índice de autores con que se califica la historia de Troya (ff. 5r-6v)», y concluye con el castigo de los griegos «después de haber con inhumana inclemencia arruinado y convertido en polvo la infeliz ciudad de Troya, teatro donde en mudas cenizas representó la fortuna la inconstancia de las majestades del mundo». Esta conclusión ético-política, se funda en una doble tradición, la de los citados «historiadores antiguos y modernos» junto a lo que llama las «tradiciones antiguas» y «la posibilidad de los sucesos». La argumentación no puede ser más retóricamente sofisticada - y sofística - considerando una prueba en sí «la tradición tan recebida en el mundo que son pocas las naciones donde no tenga lugar la memoria de Troya, para ejemplo con su ruina o para lástima con su incendio, y tiene tanta fuerza la verdad que ella sola (aun cuando faltaran historias que calificaran la de Troya) bastara para abono de su crédito, que no se diferencian la tradición y la historia en el valor y estimación». De esta forma, «si fiamos del discurso el valor de la tradición, hablaremos que es mayor el que le dan las palabras a los hombres (perdone la calunia) que el que le dan las letras en los libros, pues el uno a menos costa del cuidado se fia de lo durable de los papeles, y el otro con más atención se conserva en lo frágil de las memorias. Luego mucho más hace quien se eterniza teniendo mayor riesgo en perderse que quien se dilata a la posteridad teniendo mayor seguridad en conservarse». ¿Cuáles son las objeciones a la existencia de Troya? Su misma «admirable» grandeza, «lo suntuoso del edificio, pues eran los muros de cuarenta estados de alto y veinte de ancho. Pues ¿por qué dudaremos de esta grandeza, cuando no dudamos de la prodigiosa de aquellas pirámides de Egipto?». La analogía de los «milagros del mundo», de «otros muchos suntuosos edificios que fueron asombro y pasmo de la fama» permite fundamentar la existencia de Troya «porque, pues, cuando los juzgamos por verdaderos tendremos por fabulosos los muros y edificios de Troya, habiendo sido tan admirable su fábrica que los antiguos la confesaron obra de los dioses (ff. $2 \mathrm{r}-\mathrm{v}$ ). Justifica que «sacada a luz su verdad con las pruebas de la tradición y posibilidad de los sucesos», repara «en que la causa de haber dudado algunos de la verdad de Troya ha sido la mezcla de fábulas con que Virgilio y Homero, a fuer de poetas, escribieron esta historia, escureciendo la luz de su verdad en sombras de mentiras». Y pasa finalmente a detallar la conformación misma de la ciudad como si de un auténtico anticuario o arqueólogo se tratase: «Era atalaya del mar a vista de Dardania un monte tan robusto y eminente que cansaba su cumbre los ojos de quien lo miraba. Cercábale el mar, dando fosos de espuma a aquel natural baluarte, formándole isla de un golfo; en este, pues, fabricó Ylio un fortalecido castillo para defensa de Dardania y palacio suyo, y de su nombre se llamó Ylión, tan celebrado en futuros siglos. Para ostentación de la grandeza de Troya ilustrada por Príamo baste decir la suntuosa fábrica de su Ylión y muros, los cuales eran de cuarenta estados de alto y veinte de ancho, todos labrados de virtuosa y fuerte cantería, con innumerables torres, repartidas en breves trechos y coronadas ellas y los lienzos de la muralla de hermosas almenas de blanco mármol. El Ylión, que como queda dicho era el real palacio, estaba fundado sobre una eminente isla en el mar, constaba de ricas cuadras labradas de mármoles y finísimos jaspes; los maderos todos de oloroso ciprés. El cuarto principal, donde el rey asistía, estaba fundado sobre columnas de alabastro y los lienzos de las paredes esmaltados de varias y preciosas perlas» (f. $3 \mathrm{v})$.

Pero nunca hay que olvidar la prevalencia epistemológica de las ruinas, a las que se ha referido V. De Caprio: «All' interno degli insiemi dicorsivi dedicati alle rovine di antiche città, quello relativo alle rovine di Roma sembra dotato di tratti specifici, organizzati intorno al senso 
En el volumen coordinado por Sánchez Jiménez y Crivellari se evita cuidadosamente un único esquema de tópica y una fórmula genealógica, abriendo el abanico de posibilidades a los cuatro puntos cardinales, sin que ello suponga, ni mucho menos, la conciencia de haber agotado los itinerarios y encuadres de la tópica del motivo. Valgan como ejemplos señeros los artículos debidos a $\mathrm{E}$. Fosalba o a S. Forero Mendoza. La primera analiza con abundantísima documentación y refinada exégesis histórica cómo en el soneto XXXIII de Garcilaso (A Boscán desde la Goleta según el epígrafe de el Brocense) se lleva a término una sutil recusatio de la empresa misma. La campaña de Túnez iba a servir para compensar la imagen negativa del saco de Roma, con «una contrarréplica» donde «el séquito de cronistas, pintores y poetas que le acompañaron iban con el encargo de inmortalizar aquella anhelada hazaña y convertirla en leyenda viva, una hazaña sin parangón, de corte clásico y caballeresco, según los gustos del emperador» ${ }^{20}$. Pero Garcilaso cambia el sentido del «arrollador

della continuità, $o$ almeno della contigüità, fra passato e presente, anche quando le rovine romane appaiono come il segno di un'assenza. La stessa capacità di Roma di crescere sulla sue rovine, di alimentarsene persino, attraverso il riuso e quindi la distruzione, si presenta come supporto oggetivo di un dato che è tutto ideologico e culturale e que impedisce al discorso sulle rovine di Roma di caricarsi del senso di quella lontananza siderale che sembra connotare i discorsi letterari sulle rovine di altre città antiche» (1987: 7). A. Gnisci, al considerar a Roma «come sistema delle rovine», acudiendo a caracterizaciones magistrales que van desde Chateaubriand a Yourcenar, ha subrayado cómo en el orden mundano, el centro era Jerusalén, y el centro del centro el Tiempo de cuyo poder salva Roma, «il luogo della massima mostra fondata, vissuta, vivente dell'impero del uomo [...] l'imporsi (il Ge- stellen direbbe Heidegger) dell' urbs nell'orbi» Su evidencia se mostraría en cuatro caracteres distintivos:

1. La copresencia estratificada y simultánea en el tejido urbano de los recuerdos de las varias Romas, en que «la città si configura come il sistema simultaneo vivente di tutte le sue precedenze»

2. La propiedad de las ruinas. «Esso consiste nel fatto che Roma è riconoscibile proprio mediante la sua totalità di sistematicità vivente di precedenti sopraviventi».

3. «Roma come sistematicità totalizante ma aperta delle sopravivenza. La città è eterna perchè vive e fa vivere le proprie rovine, ma non è una rovina».

4. La visibilidad espectacular que ofrece al visitante. En Roma no hay lugares que puedan visitarse, «essa invece, si offre tutta intera come luogo deputato di esposizione della vicenda storica degli umani, nella forma eterna dell'urbs» (De Caprio, 1987: 11-19).

${ }^{20}$ Morán Turina explica convincentemente el proceso de cambio hacia las ruinas de Cartago que supuso la expedición carolina: «Las ruinas de la miserable Cartago esparcidas por todo el territorio y dominadas por la silueta de los imponentes acueductos y por aquella poderosa torre que creían fue el mítico corral de los elefantes. Aquella fue una impresión que no olvidaron nunca y que les permitió encontrar entre las ruinas de Cartago lo mismo que los franceses y los hombres del norte habían encontrado entre las de Roma [...]. Tras la campaña de Túnez, Cartago había dejado de pertenecer al mundo legendario en que se ubicaban Troya, Jericó y Babel, para entrar a formar parte de una realidad tangible de la que había imágenes concretas [...]. Fueron muchos quienes supieron de ella por los relatos y las crónicas de los que participaron en la empresa y por los numerosos grabados de los alrededores de Túnez que circularon en los 
avance de las tropas del emperador tierra adentro, y como por arte de magia, las huestes, a su paso triunfal riegan y hacen reverdecer el suelo africano, al tiempo que se va abriendo una brecha al lamento amoroso y a la implícita reflexión ontológica de los tercetos a lomos de unas sutilísimas dilogías que recorren el poema y logran darle la vuelta por completo, en el epifonema, a su sentido inicialmente victorioso» (2019: 74-79) ${ }^{21}$. E. Fosalba desenvuelve con acierto el contacto «en la memoria poética de Garcilaso» del famoso Superbi colli de Castiglione con el que Bernardo Tasso escribió a propósito de la misma jornada («Sacra ruina che'l gran cerchio giri [...]», aunque en el poeta toledano la repetición y la circularidad del tiempo de este poema no se expliciten, «pues solo se halla tácita en el motivo de las ruinas que afloran silenciosas por la referencia al soneto de Castiglione (pp. 94-96).

Por su parte, S. Forero Mendoza, establece que «las ruinas alimentan una tradición poética universal, no constituyen siempre el objeto de una representación». La representación descriptiva de las ruinas nació con el Renacimiento y durante el siglo XV ya se convierte «en un motivo iconográfico, encargado de significar el hundimiento del orden pagano, anterior al cristianismo» ${ }^{22}$. A lo largo del XV la representación de las ruinas «parece dar lugar a variaciones infinitas $^{23}$, mientras surge el redescubrimiento de los restos antiguos y su

años posteriores [...] Incluso la propia historia antigua de la ciudad se hizo extrañamente actual y presente cuando, por una especie de justicia poética, se vio en la victoria del emperador sobre Barbarroja la justa venganza, largo tiempo demorada, que se cobraban los españoles por la derrota que les infligieron los cartaginenses cuando destruyeron Sagunto más de mil años atrás». El propio Morán realiza una concreta síntesis de la presencia de las ruinas de Cartago entre Fernando de Herrera y Luis de Góngora (con el estremecedor verso del soneto de senectute «Confiésalo Cartago ¿y tú lo ignoras?» (2010a: 65-71 y 98-100). Véase el contexto histórico en profundidad que traza V. Beltrán (2017: 45-114).

${ }^{21}$ Sobre los tópicos de la tradición clásica del motivo de las ruinas en el soneto garcilasiano visto como «una querella pacis» véase la exhaustiva anotación sobre la «compleja trama de sentidos sobrepuestos que es preciso elucidar» en el correspondiente apartado de «Comentario y notas» (en Garcilaso de la Vega, 2017: 202-206). «Garcilaso parece querer decir que la destrucción militar, como el amor, no implica creación o renacer, sino quizá suponga esterilidad y desertización absolutas: la destrucción y/o el amor» (p. 203).

${ }^{22} \mathrm{Y}$ que tuvo un eximio ejemplo en los diseños de arquitectura de la Grecia antigua reunidos por Sangallo en su Libro (Códice Barberiniano latino 4424). Se trataba de reconstruir por procedimientos diversos acompañados de comentarios el paisaje arquitectónico de la Antigüedad, organizado en secuencias más o menos coherentes (entre ellas 27 piezas de grandes complejos templarios o de arquitectura defensiva) (Donetti, 2013: 85-88).

${ }^{23}$ Como recuerda S. Frommel, el tema es motivo de reflexiones complejas y se articula en diversidad de formas. Las innovaciones de F. Brunelleschi y Donatello en Florencia en la segunda mitad del xv, el De Re Aedificatoria de L. B. Alberti (1432) o la Sforzinda de Filarete (1460) configuran fórmulas a las que se integran las invenciones clasicistas en el tema de la Adoración de los Magos (a S. Botticelli se deben cinco de estos cuadros concebidos entre 1466 y 1500), que perderá actualidad en la segunda mitad del Renacimiento (en Kaderka, 2013: 95-99 
examen por parte de arquitectos y humanistas transformados en arqueólogos [...] pero habrá que esperar al siglo XVI para que se amplíe el círculo de los temas donde figuran ruinas». Es en esta centuria y en la siguiente, con su apoteosis en el siglo XVIII, cuando «se constituye un imaginario ruinista europeo». Con el Autorretrato delante del Coliseo (1553), M. van Heemskeck es un representante eximio de los dibujantes y pintores holandeses y flamencos de la primera promoción de artistas que «trabajan para fijar la imagen de la ciudad antigua en ruinas» y definir el género de la veduta, donde estas «se convierten en un tema en sí mismo, un tema cargado de alusiones al paso del tiempo y a la desaparición de todas las cosas») Se detiene en el análisis del Paisaje con ruinas romanas de H. Posthumus (1536), cuyo propósito es hacer de este paisaje «una vanidad a cielo abierto», y representación de una «estética del colapso» en que su significado tiene una dimensión más universal y su evocación se dota de acentos melancólicos que exaltan su belleza propia de las formas degradadas, «sin dejar de transmitir la esperanza humanista de una supervivencia de la Antigüedad». La mayoría de los pintores de ruinas fueron discípulos de Jan Van Scorel y formaron la comunidad más amplia de los denominados fiamminghi (pp. 61-65). Sigue la estudiosa la evolución cronológica y formal del mercado del grabado y la estampa desde el llamado «El Gran Libro de las ruinas» de H. Cock a las denominadas «vistas compuestas» de P. Brill, donde las ruinas son un elemento más del cuadro de paisaje, determinando los procesos que conducen a la diferenciación del paisaje con ruinas, el paisaje de ruinas y el «paisaje histórico que sirve de marco a fábulas mitológicas o religiosas». Alrededor de 1630 «Roma es la capital de las artes» y el crisol de la pintura de paisaje, a la que darán vuelo definitivo artistas como A. Carracci y sobre todo Le Lorrain, con el que «la representación de las ruinas antiguas se convierte en un estereotipo en unas obras que exaltan su majestad arquitectónica y explotan sus posibilidades decorativas y constructivas». Un análisis detenido de sus aportaciones, junto a las contrastivas «bambochadas» (con escenas de diversiones campestres, fiestas de bebedores y «conjuntos de bohemios y gitanos») definen la triple función (simbólica, constructiva y

\footnotetext{
y 105-106). N. Dacos realiza el más completo análisis de las pinturas del paisaje de Roma, desde el cuadro de N. Posthumus, de 1536, a un dibujo del Rijksmuseum, de 1556, pasando por los pintores flamencos de la Domus Aurea de Nerón y artistas como J. van Scorel, Marten van Heemskerck o Jan Cornelisz Vermeyen, para concluir en una síntesis explicativa clave para entender el proceso de contitucion del «paisaje de ruinas»: «Cuando en su poema didáctico Van Mander lamenta que en Roma los fiamminghi no sean apreciados por las figuras y que se les relega a la pintura de pequeños paisajes en los grutescos, la situación que describe es no solo la que ha vivido hacia 1575, pues Michel Gast había sido ya el primero en convertir este género en su especialidad. Con Heemskerck y sus discípulos, y luego con sus seguidores, la visión nacida en el taller de Scorell se impone en Roma para extenderse por toda Europa» (Dacos, 2014: 275294); véase asimismo J. C. D’Amico y A. Testino Zephiropoulos (2012).
} 
decorativa) que van a fijar «los trazos de un imaginario» colectivo «ruinista» cuyo éxito atravesará el siglo xVIII con la realización de los jardines «ingleses» introduciendo como elemento imprescindible la edificación de falsas ruinas (pp. 67-71) $)^{24}$.

Pero calibrar un volumen colectivo supone también el trazado de unas identidades explicativas y de unas ausencias que no lo hacen desmerecer, en absoluto, de su específica y notable aportación al estudio del tema, prácticamente inagotable, pero multiforme y diversificador, del motivo que es su objeto de análisis. Por lo pronto hay que subrayar cómo en los diferentes ensayos existe una preocupación por resituar las ruinas como objeto de meditación que va más allá de considerarlas simplemente el apex temático cuya tópica refleja, de forma más o menos directa, la condición especular con la propia vida humana. Un signo cuasi unívoco de la pugna permanente entre cultura y naturaleza, hombre y tiempo, en cuyo centro fulge la humana conditio de un ser irremisiblemente perecedero, dotado de la capacidad para crear las maravillas arquitectónicas que ahora denuncian —con mayor o menor énfasis melancólico- su misterioso complejo de naturaleza viva y cambiante, de perennidad corroída $\mathrm{y}$ fugacidad hecha de fragmentos y olvidos ${ }^{25}$. No se ha querido aquí, en

${ }^{24}$ La mediación de la pintura con la compacidad del libro de emblemas, en la equiparación de naturaleza y arquitectura, se muestra todavía, de forma condensada e inequívoca, en esta alegoría de Ginés Campillo de Bayle. «Llevaba asimismo el Carro de la Vida, a las espaldas de la popa, otras varias pinturas, pero por rendidas eran como despojo, del valor y por postradas como triunfos del tiempo. El valiente pincel las supo colorear tan a lo lejos que, con estar presentes, fingían la distancia tan allá retirada que era menester esforzar la vista para percibirlas: edificios arruinados, torres demolidas, pirámides postradas, tribunales caídos y árboles cortados eran los que a la perspectiva se enseñaban distantes. Lo que eran y significaban aquellas figuras se entendía por estos versos que, de letras de oro, en aquellas espaldas hacían bello rostro: "Cayeron los alcázares seguros, / las pirámides fueron derribadas, / a ruinas pasáronse los muros / como el verdor a flores deshojadas; / estos son de la vida premios duros, / de tanta vanidad glorias ganadas, / sólo quedaron entre llanto y quejas, / con cercano ejemplar, memorias lejas". Las memorias del tiempo que son las que algo remanecen en la vida, eran aquellas postradas ruinas y aislados homenajes, mirados del ejemplo, caducos, que ya pasaron, lejos que apenas se perciben. Que lo que más se afianza a la duración, por entendimiento de los hombres, en breve llega a cenizas por memoria de los siglos» (Gustos y disgustos del Lentiscar de Cartagena, Valencia, Francisco Mestre, 1691, pp. 72-73).

25 A la filosofía de la historia hegeliana y sus propósitos de representación general deben algunas de sus aporías menos aceptables las reflexiones de J. Bialostocki (1973: 193-209) y J. M. Greene (1982: 231-234). Pero, en contra, conviene aquilatar la precisión de coordenadas de orden lógico-semántico y raíz hegeliana con que V. De Caprio ahonda en las conexiones entre ruinae y monumenta (1983: 24-28), considerando desde las Elegantiae de Valla el eje semántico del verbo moneo (monumentum), desde su inicial sentido a aquel en que asumen la virtus de los antiguos y también «il ciclo delle costruzioni e delle distruzioni» para culminar en un procedimiento donde «il percorso del passato verso la corruzione si cambia nel percorso verso la rinascita futura. Il procedimento diventa circolare: monumenta-ruinae-monumenta». 
definitiva, situar sin más a las ruinas poéticas bajo el doble signo retórico de Saturno y Cronos. Con ello se retrazarían los contornos de añejos discursos cargados de frágil entidad meditativa, discursos de topicidad neorromántica sobre la captación verbal del choque entre fuerzas telúricas y producción material, entre el poder creador y el poder del tiempo. Ni siquiera en el marco de una filosofía relativista sugeridora de un mensaje, sin más, de pérdida y desesperación. Ahora las ruinas se abren en su multiplicado carácter de tópica emblematizadora a la pluralidad de lo inmemorial atrapado por los discursos poéticos, esto es, se abren a un plural constituyente de emblemas verbales (o imaginísticos): monumentos, en fin, de la simplificación polivalente y objeto de perplejidades y preguntas. Si algo hubiese que resaltar en el volumen es la voluntad común de realizar lecturas históricamente fundadas $-\mathrm{y}$ suficientemente documentadas- de una tópica tan fluyente como deslizante. La relección, en suma, de exégesis concretas sobre un continente en que las ruinas han dejado de ser vistas como presencia perecedera, un valor genérico que derivaría de la literatura clásica, y todavía no comportan más que aisladamente el sentido inmanentista y voluptuoso de la hybris romántica ${ }^{26}$. Lecturas, pues, de un espacio caracterizado por el valor de signo múltiple, de indicio que cumple funciones mediatizadoras soportando un abanico vario de discursos (histórico, filológico, moral o filográfico, entre otros).

Una atención a la peculiar poética de las ruinas en el Siglo de Oro no debía circunscribirse a establecer las coordenadas temáticas y la variabilidad retórica y estilista del motivo ${ }^{27}$, como si se tratase de una evolución interna e

${ }^{26}$ La riqueza de matices, la hondura de las observaciones y comentarios sobre una panoplia extensa de poemas (aunque no falten las repeticiones), el directo acopio de textos (exhaustivo, por ejemplo, en el caso de Lope de Vega), compensan con creces el recurso reiterado a ciertas formulas no bien definidas y las contradicciones que pueden espigarse entre algunos ensayos y otros. Pero véase una estructuración temático-formal estratificada y diacrónica en las aportaciones de A. Manacorda y A. Carandini, entre otros, en la colectiva Storia di Romas, III (1993), o el conjunto distribuido en planos de significación siguiendo procesos tematológicos y semánticos del volumen coordinado por K. Kaderka (2013), de los que me he servido en la distribución analítica de mis consideraciones en segmentos coordinados.

27 Valga como argumento de la variedad de sentidos insertos en la tradición del motivo cómo la misma y esencial tesis del Superbi colli, con su configuración ponderativa de ruinas y amor, tiene su correlato contrapuesto en la poesía fúnebre y lamentatoria. Un ejemplo sobresaliente por el tono elegíaco y la intensiva superación del paradigma comparante puede ser, entre otros, uno de los sonetos de la serie dedicada a lamentar la muerte de la amada de Bertiso, el sevillano Félix Persio: «No quedó Troya tan sin ser mi guarda / después que abrasó el fuego sus cimientos, / formando nubes por los turbios vientos / de sus reliquias la ceniza parda; / ni Roma, que ambos polos, acobarda / después del triste incendio y sus lamentos, / como mi pecho, ser y pensamientos / con la temprana muerte de Rosarda. / Fue Rosarda mi bien, mi sol, mi luna, / mi cielo, mi favor, mi margarita, / mi riqueza y reparo de mis daños. / Y mirad si es mudable la fortuna / pues que en un punto con rigor me quita / más que pudiera darme en cien mil años» (Navarro 
inmanente en la que habría de aflorar la mutación ininterrumpida de un proceso a la vez de sensibilidad histórica y búsqueda de sentidos. Las inflexiones modales y del sistema retórico-estilístico aparecen aquí interactivando con una ideología inestable, fluctuante e impermanente, que se explica por los sucesivos descubrimientos de funciones mediatizadoras en parte o radicalmente innovadoras. Es una dialéctica que inicia el primer descubrimiento moderno de las ruinas, aislado en una absence que llega hasta finales del XV (JoukovskyMicha, 1969: 111-114)28. El de un Petrarca que asocia la laudatio y la deploratio para, dentro de la común ideología de la Roma renovata, acercarse a la subjetiva resonancia ante los restos de la Roma pagana, en un excurso de su Carmen metricum (II, 15):

Quot sunt mihi templa, quot arces, vulnera sunt totidem. Crebis confusa ruinis moenia, reliquiae inmensae protinus Urbis ostentant, lacrimasque movent spectantibus ${ }^{29}$.

Durán, 1983: 202). Pero la ausencia de consideraciones filográficas terminará por imponerse en la poesía del último Barroco. Valgan por todos estos dos significativos sonetos de García de Salcedo Coronel: Acordándose de la brevedad de la vida con ocasión de ver unas ruinas de un grande edificio, junto a un palacio suntuoso: «Corre el tiempo veloz, y tú olvidado / del fin que te amenaza presuroso / en tu misma inquietud buscas reposo / de engañoso favor lisonjeado. / Si este que ves, de estrellas coronado, / edificio, te alienta suntuoso, / mira aquel, que te ofrece lastimoso / escarmientos, del tiempo derribado. / No resiste rebelde la dureza / de las piedras la injuria de los años / que en leve polvo desvanece el viento. / Reconozca el discurso su flaqueza, / que faltan eficacia a los engaños / contra la viva voz del escarmiento»; A las ruinas del anfiteatro de Capua: «Esta ruina que corona en vano / inútil yedra, con infausta gloria, / testigo un tiempo de infeliz victoria, / oyó lisonjas del aplauso humano. / Aquí donde el arbitrio dio tirano/ rígido asunto a esclarecida historia, / apena haya libre la memoria / breve luz de esplendor tan soberano. Rústico arado ofende inadvertido / la excelsa majestad cuya grandeza / idolatraron bárbaros errores; / todo la edad lo trueca y el olvido / ¿y quiero yo que dure la firmeza / de Lisi, más constante en sus rigores?» (Cristales de Helicona, ff. 1v-3r).

${ }^{28}$ En el epígrafe rotulado «Une absence des ruines» indica que hasta las primeras décadas del Xvi «on ne décrit pas les ruines: on voit s'effondrer les monuments anciens. C'est le moment de la chute qui intéresse les poétes, non pas la calme beauté des champs de pierres». Y cita como excepcional un pasaje del Voiage de Venise (1509) de J. Marot: «Les grands pallays, theatres, collisées, / tous desrompaz et medailles brisées, /ou Eupereurs et Chefz des creatures / soulogent menger, estoyent fange et ordures». Sobre las ruinas en Petrarca, desde el Carmen metricum véase, como introducción panorámica, A. Buck (1989: 41-52 especialmente).

${ }^{29}$ Aunque Petrarca no escapa a muy concretos impulsos determinados por «la causa del ritorno della sede papale a Roma» que «in vista delle sue recenti esperienze romane essa era ora piú cara che mai alla sua mente e al suo cuore» (Wilkins, 1980: 56). La singularidad del Carmen vendría dada por la didáctica entre «l'extratemporale e il quotidiano» que con tanta lucidez ha enunciado U. Dotti (1992: 41-55). Sobre el mito de la Roma antigua, el modelo heroico que conforma Petrarca sobre la misma y sus connotaciones políticas véase del citado U. 
El descubrimiento de Petrarca es en realidad un hito simbólico ${ }^{30}$, ya que su labor admirativa por la Roma antigua y el encauzamiento en su poesía latina y su epistolario (baste recordar la importancia para la arqueología de una carta suya de 1349, en que da cuenta de cómo un terremoto ha afectado al Coliseo: «Cecidit aedificorum veterum neglecta civibus, stupenda peregrinis moles») han sido puestas siempre como punto de inflexión de una serie de aperturas hacia la modernidad. Por una parte, y como resulta de particular interés para estas páginas, por servir de pórtico a un extenso tratamiento del tema en la poesía neolatina, que siempre precede y en buena medida modelará la eclosión del motivo en las literaturas en lengua romance. De su profusa variedad puede dar ejemplo la recopilación publicada en Roma por Jacobo Mazochius en 1521 bajo el título de Epigrammata antiquae urbisis ${ }^{31}$ Se trata de una lírica cuyas predicaciones abarcan desde el sentir elegíaco del De Raphaelis morte de B. Castiglione a las descripciones de monumentos y ciudades (la Cumas de Sannazaro) y la dominante reflexión sobre la fortuna labilis, a la que también relevaría la prosa histórica de Poggio Bracciolini con el expresivo título De Fortunae varietate urbis Romae et de ruina eiusdem descriptio ${ }^{32}$.

Por otro lado, la idea de la renovatio urbis va calando en la conciencia histórica de los humanistas hasta amalgamar una síntesis de presente y pasado, clásico y sagrado, a la que enfatizará Albertini en su De mirabilibus novae et veteris urbis Romae, de $1510^{33}$. A propósito de las «ruinas deshabitadas», M.

Dotti (1992: 129-158), además de la síntesis magistral de A. Mazzocco (1987: 53-94), quien asegura que «il padre dell'antiquaria rinascimentale è Francesco Petrarca» (pp. 59-61).

${ }^{30}$ Para toda la trayectoria de recuperación arqueológica desde el Trecento hasta la publicación a mediados del xv de la Roma instaurata y la Roma triunphans de F. Biondo remito al documentado panorama de A. Gómez Moreno (1994: 242-258). Destaca justamente la labor de artistas «en la copia de inscripciones» lo que conducirá a la sólida erudición arqueológica de un A. Mantegna, y la «desmedida pasión» con que se buscaron los restos de Tito Livio, Ovidio y Virgilio.

31 Todas las referencias imprescindibles, comenzando por la antología clásica de PerosaSparrow, están recogidas en los documentados artículos de M. Ruiz Sánchez (solo o en colaboración) a los que me iré refiriendo con cierto pormenor, por constituir un aspecto generalmente desatendido en los acercamientos al motivo de las ruinas. Véase además L. Cellerius (en Kaderka, 2013: 95-112) y J. Cl. Maire Vigueur (2010).

32 Un selecto repertorio de libros no poéticos sobre la Roma de la tradición medieval y renacentista se hallará en los diversos artículos reunidos por V. De Caprio (1983: passim), quien destaca, entre otros, a P. P. Vergerio, E. S. Piccolomini, Poggio Bracciolini y C. Landino. También, complementariamente, A. Vauchez (2006) y los artículos de A. Carandini y D. Manacorda en la colectiva Storia di Roma (1993, III).

33 Para un adecuado encuadre teórico de cómo cada época ha conformado un imaginario de la Antigüedad clásica, véase P. Guzzo (1993) y en lo que respecta a Roma, V. De Caprio, «Sub tanta diruta mole. Il fascino delle rovine di Roma nel Quattro e Cinquecento» (1983: 20-52). Además, en general, los colectivos dirigidos por A. Giardini (1986), A. Vauchez y A. Giardini (2000) y J. Cl. Maire Vigueur (2000). 
Ruiz Sánchez ha recorrido con abundante ejemplificación el papel de la tradición neolatina (que remontaría, en último término, a las composiciones modélicas de la Antologia palatina). La vertiente elegíaca tiene netos antecedentes también en la poesía latina clásica, comenzando con el imprescindible Propercio (IV, 1) en estrecha relación con Tibulo (elegía II, 5) y por la imitación de ambos en los Fastos ovidianos. Claves paralelas suministrará el libro vIII de La Eneida virgiliana, aunque en este caso no se muestra «el pasado idílico como trasfondo de la civilizada realidad actual», sino que con su futuro (que equivale, por tanto, al presente actualizado del lector) se genera un complejo «juego de proyecciones temporales», modificado por Lucano (Farsalia IX, 964-979) aplicado a la contemplación de las ruinas de Troya por César y que sirve para una «puesta en abismo». Frente a la poesía clásica, la lírica neolatina invierte las conexiones de representación «y el contraste se establece entre la grandeza que representan las ruinas actuales y el presente de las ciudades destruidas». Un interés parejo al arqueológico y fundamentado en factores políti$\cos$, con el correspondiente desconsuelo ante la realidad actual, puede resaltarse en el poema de Cristoforo Landino De Roma fere diruta, con referencias espaciales de valor simbólico como «aemula caelo: olim tectis moranda superbis» (v. 3) o «alta quid ad caelum, Tite, surrigis amphiteatra» (v. 11). La presencia del testigo proveniente del pasado y el cierre de la composición recuerdan perspectivas y encuadres del epigrama de Eneas Silvio («Nullum hic iudicium nobilitatis erit») o de otro debido a Conrado Celtis («Nomen Romanum vix superesse reor»).

Uno de los modelos más conocidos e imitados fue debido a Sannazaro: $\mathrm{Ad}$ Ruinas Cumarun urbis vetustissimae, que añade «a las notas bucólicas habituales desde la Antología los motivos de la caza de animales peligrosos en los lugares antaño habitados y los signos característicos del locus horridus». En un marco imaginario novedoso se incardina, mediante una estructuración circular, la reflexión «sobre la muerte de las ciudades» (Roma, Venecia, pero también la Nápoles natal) mediante una «relación simbólica» por la que «los testigos solo intuyen parcialmente lo que constituye el núcleo minucioso de la propia realidad». Con parecido desarrollo otro poema neolatino de Sannazaro, In theatrum Campanum, sustituye el contraste temporal por el tópico del ubi sunt?, terminando, de forma muy semejante con una sentencia sobre el poder del destino y del tiempo, en la huella de la descripción de las ruinas de Populonia por Rutilio Namatiano, que conduce ya la lectura del motivo a la poesía fúnebre, convirtiéndose en «una lección de memento mori» (Ruiz Sánchez, 1999: 354-361).

De particular interés es el juego intertextual y las referencias cruzadas que se detectan entre los poemas de Du Bellay y sus epigramas neolatinos, como 
la elegía Tiberis ${ }^{34}$. El autor utiliza aquí elementos parecidos a la Roma descriptio para darles un alcance diferente (así, la imaginería del renacimiento culmina en el símil del viejo tronco del que nacen nuevos retoños, imagen que queda próxima a algunas de las comparaciones de los sonetos en francés). En esta elegía las ruinas son ocasión de elogio y Du Bellay afirmará, invirtiendo el motivo, que Roma sobrevive (Roma tamen super est), exceptuando de las ruinas precisamente el Capitolio, la parte más simbólicamente noble de la ciudad (pp. 366-369). En otro reciente estudio en colaboración el mismo estudioso ha trazado innovadoramente la proyección del Superbi colli, deteniéndose en la serie nutrida de paralelos neolatinos. Por lo general se atendía al De Roma de Lazzaro Buonamici, difundido por las Delitiae (1608), expresión canónica del epigrama demostrativo moralizante sobre ciudades desaparecidas que se asociaba a la temática fúnebre. Pero en la serie de imitaciones desatendidas, la del Superbi colli introduce la invocación en segunda persona, las ruinas son interpeladas y la reflexión final acoge los sentimientos más diversos donde las ruinas introducen en el contraste temporal su condición de exemplum «y de la enseñanza personal que las convierte en símbolo del espectador». Algunas funciones del tópico en la poesía neolatina son similares a las recreaciones del Superbi colli, y es muy difícil llegar a discernir lo que la tradición del tema debe puntualmente a cada poema, por producirse una eficaz y constante «interacción de modelos $\rangle^{35}$. El contraste entre las ruinas y el amor, por ejemplo,

${ }^{34}$ El eco de esta elegía llega a un excelente soneto de Luis Vélez de Guevara: «Turbias aguas del Tíber, que habéis sido / de puentes y arcos mármoles triunfales, / para mirarse espejos y cristales / donde como Narcisos han caído. / Ya vuestras aguas son las del olvido, / pues destos edificios principales, / las piedras, los cimientos, las señales / habéis en las arenas escondido, / y solo una señal, solo un cimiento / en un remanso escasamente asoma / de aquella puente que os sirvió de yugo. / Por vos quedó en el mundo el sentimiento: / mucho ayudáis al Tiempo contra Roma / pues que sois de sus fábricas verdugo» (recogido en la Segunda parte de las «Flores de poetas ilustres» de España, p. 200). La bibliografía sobre Du Bellay era ya inabarcable cuando se publicaron los estudios de G. Demerson sobre sus reversiones neolatinas y francesas (1984), de A. Michel, acerca de su relación con la poesía latina clásica (1991), de G. H. Tucker sobre el triángulo conformado con Lucano y Janus Vitalis, en un colectivo de variado interés (1991), o de F. Giordani sobre la utilización simbólica del espacio en Antiquitez, en otro colectivo dedicado a los sonetos (1994).

35 Fuera del ámbito francés, S. Graciotti indicó ya la profunda huella de epigrama de Vitalis, desde el Epitafium Rzymowi [A. Roma] de Sep Szarzyński, quien parece haber estado en Italia hacia 1565, a Sulla Roma presente de Nicodemo Czeczel (publicado en 1758). Piensa, sin embargo, en la posible mediación de las Antiquitez de Roma del renacentista francés. El epigrama del polaco es aducido, sin atender a las conexiones que estableciera Costa Ramalho, como fuente fragmentaria del soneto de Quevedo, lo cual resulta improbable porque se acerca a él tan solo cuando reescribe el epigrama de Vitalis o conserva íntegros versos enteros, pero diverge en los escasos instantes en que realiza un cierto despegue del polaco respecto al original (Graciotti, 1960: 124-185). El poema de Janus Vitalis ha sido fechado en 1552, año en que apareció con el título Roma Prisca en el volumen Sacrosanctae Romanae Ecclessia elogia. Véase ahora, además, R. Cacho Casal (2012: 191-193), sobre la tríada conformada por Du Bellay, J. Vitalis y Quevedo. 
aparece en el epigrama De sua poena inmutabili de Girolamo Angeriano, incluido en el Erotopaignion (de 1512), aunque ahora la ley universal de que todo tiene fin deja fuera el tormento amoroso del poeta, que carece de término. Otros tres poemas neolatinos habría que aducir y que son objeto de análisis en el estudio considerado: el Spes de Pierangelo Bargeo (1568), el Excelsi colles Urbis, sacraeque ruinae de Niccolo d'Arco (cuyo fallecimiento en 1546 permite deducir la temprana circulación del texto de Castiglione) y el Colles alloquitur Romanos (1591) de G. C. Scaligero (pp. 8-16).

En definitiva, un análisis correcto del motivo de las ruinas tiene que atender a cómo cada descubrimiento de la lírica renacentista y barroca tiende a reconocerse en determinados modelos directa o indirectamente neolatinos, casi siempre en un sistema de imitación compuesta (o «de varios») que constituye la fundamentación de una serie de reescrituras del motivo en grados de personalización variables. Por desgracia la crítica ha privilegiado una forma de vulgar positivismo, por la que se ha venido reduciendo a Superbi colli y poco más las variaciones modelizantes. Y además, sin tener en cuenta la vehiculación sincrónica de los modelos latinos y neolatinos, en las formas varias de cruces y sinfronismos, desde el común sustrato de la cultura humanística y el multiplicado cruce de valencias simbólicas y diseños retóricos abiertos. Lo cual no supone obviar, sino subrayar de distinta forma, cómo una correcta filiación textual constituye el requisito primario para la intelección de la tópica en un motivo tan amplio como el de las ruinas. Solo tras el encuadramiento en su correspondiente cadena temática el poema revela la peculiaridad de su organización retórica y de su compromiso de significado. Un ejercicio metodológico que permite desentrañar parecidos o afinidades más o menos profundas entre creaciones que hasta ahora solo aparecían como términos de una extensa serie indefinida.

Tras un pionero artículo de A. Morel Fatio (1894: 97-102) que relacionaba Superbi colli con tres sonetos españoles y dos franceses, R. Foulché-Delbosc (1904: 225-243) recogió, tras detenerse particularmente en las variantes textuales del soneto de Cetina, hasta quince sonetos sobre ruinas, en su mayoría escasamente conectables con el supuesto modelo, pese a lo cual llegaba a la increíble conclusión de que «on peut tirer de rapprochement de ces diverses pièces, c'est que la poésie des ruines a eté souvent, en Espagne, exprimé d'une manière peu variée. Mais si Troie, Carthage, Roma, Sagonte, Italica, n'ont inspiré que des pensées sensiblement pareilles, cela tient moins, semble-t-il-à l'identité des sujets qu'a ce fait que toute cette littérature est le décalque —ou parfois la paraphrase- d'un même sonnet italien». Fucilla (1955: 51-93) reprodujo lo esencial de la documentación de Foulché-Dolbosc y añadió dieciséis versiones nuevas del tema. Pero aunque aduce modelos distintos, como un conocido fragmento de la Gerusalemme de Tasso y dos sonetos de 
Sannazaro y Ludovico Paterno, sigue obsesionado por el prestigio del soneto de Castiglione, difundido junto con el de Cetina por las Anotaciones de Herrera, que serían así «fuente inmediata de información [...] de importancia decisiva en la difusión del motivo y del molde que suministró a otros poetas». La verdad es que aducir, sin más, el Superbi colli es desatender al conjunto de ramificaciones que se producen desde su génesis misma, y cuyo elenco cuenta ya desde hace décadas con una bibliografía multiplicada. Porque el soneto de Du Bellay, sobre cuya prioridad y absoluta originalidad la investigación positivista derrochó ingenio y tinta, es en su esencia una reescritura del epigrama neolatino debido a Janus Vitalis. Ya A. Costa Ramalho (1997: 310) antologó e incluso estableció un diagrama de las imitaciones de este poemita que llegaría hasta el soneto de Charles de Chênedollé (1769-1833) Rome ensevelie dans ses ruines. Esa huella ha sido analizada con particular detención en Du Bellay y J. Doublet por R. Mortier, quien llegó a formular las claves de la fortuna europea de Vitalis, publicado en 1552 y recogido por varias antologías neolatinas desde $1554^{36}$. A más de su extensión simétrica al molde vehicular en que fue tantas veces vertido (el soneto), habría que resaltar la simétrica y perfecta ordenación retórica de su patetismo descriptivo en torno al doblete victa-victric, el tono apelativo directo con que expresa el extrañamiento del contemplador, y el concepto ingenioso de oponer el movimiento perdurable a la inmovilidad condenada de las ruinas.

36 R. Mortier también destaca otros ejemplos de lo que considera «un des topoi préféres de la littérature néolatine»: la elegía de Giovanni Battista Spagnoli a la muerte de su discípulo Alessandro Cortese, en la que «l'accent est mis sur les concepts de grandeur ou de déclin», y el De Roma fere diruta de Cristoforo Landino, donde «la ruine este symbole de honte: objet détruit ou pourrissant, elle jette le descrédit sur l'homme moderne, ce barbare». Si es verdad que, como hace notar poco antes, «dans l'esthetique classique [...] l'idée de ruine s'associe à celle d'une grandeur passée, d'une oeuvre prestigieuse témoignant de la puissance ou de la splendeur d'une civilisayion disparue», y por consiguiente, en la clarificación de los estilos «la ruine appartient le plus souvent au style haut (palais, monuments)» (1974). La poesía barroca española desborda ese estatuto de decoro retórico y da cabida frecuente a ruinas de lugares poco ilustres, innominados o cargados de una afectividad íntima para quien los contempla. Un caso ejemplar es el soneto de Enríquez de Arana Acordándose de la brevedad de la vida huma, al ver la ruina del mismo cuarto en que nació: «¿Quién te aparta ligero pensamiento / del dolor que produce mi cuidado, / cuando miro en la yerba reclinado / el techo que asombró mi nacimiento? / Este, que ayer jugaba con el viento, / despreciando los ímpetus del hado, / hoy entre sus cenizas sepultado / me vende en cada piedra un escarmiento. / ¿Cómo, viendo disuelta la firmeza / de este edificio, que contemplo estrago, / me podré asegurar en mi flaqueza? / Tema del tiempo ya el presente halago, / pues vuelto en ruinas de infeliz tristeza / me señala una muerte en cada amago» (1996: 234). 


\section{De Roma}

Qui Roman in media quaeris novus advena Roma,

et Romae in Roma nil reperis media;

adspice murorum moles, praeruptaque saxa,

obrutaque horrenti vasta theatra situ.

Haec sunt Roma: videm velut ipsa cadavera tantae

urbis adhuc spirent imperiosa minas?

Vicit ut haec mundum, nixa est se vincere: vicit,

a se non victum ne quid in orbe foret.

Nunc vincta in Roma victric Roma illa invicta est?

Atque eadem victric, victaque Roma fuit.

Albula Romani restat nominis index,

Qui quoque nunc rapidis fertur in aequor aquis

Disce hinc quid possit Fortuna: inmota labascunt, et quae perpetuo sunt agitata manent ${ }^{37}$.

Quevedo se sintió atraído por la introducción apelativa incardinada en él al procedimiento de recoger y englobar al lector en el compromiso plural del «peregrino». Que significa tanto al mediato contemplador de las ruinas como al hombre en la dimensión transitoria y fugitiva, que refleja el devenir inexorable de su obra por grande y hermosa que sea. Pero la estructura de sentido caracterizada como «una trabazón de relaciones abstractas en el contraste

37 Trascribo el texto que trae A. da Costa Ramalho (1952: 60 y también 1997: 300); otro con variaciones textuales, figura en V. De Caprio (1987: 46). Con Du Bellay el juego intratextual de Quevedo llega a ser de enorme complejidad al revertir este su soneto al cauce neolatino, según analizó G. Demerson (1984: 113-128). Véase además para una ampliación de los contextos explicativos los estudios insuperados de A. Michel (1991) y G. H. Tucker (1991). Ensaya una relectura comparativa que «met en lumière la renouvellement profond qu'aporte Du Bellay», F. Giardini (1994: 33-36 en particular). Vuelve sobre ello, enfocando «algunos de los usos de la retórica» en las imitaciones de Quevedo y Szarzýnski, B. Baczýnsta, quien concluye que el soneto de aquel «presenta cierta afinidad con el epigrama polaco» pero fue «compuesto independientemente». El elenco más amplio de imitaciones de Vitalis, que adelanta su influencia en la lírica neolatina hasta el epitafio In urbem Roman de Andreas Frusius, es el realizado por M. C. Smith (1996: 31-42), quien recogió y comentó hasta dieciocho composiciones, finalizando con el soneto de Quevedo. Para una confrontación del De Roma de Vitalis con algunos de los Epigrammata in Italia Scripta de Panonius, véase en particular R. Skyrme (1982), a más de cuanto se apunta en estas páginas. El trayecto hasta la elegía IX del libro II de J. Sannazaro es trazado por V. De Caprio (1987: 46-51); en otro sentido, puede seguirse el trazado que conduce a Du Bellay y Vitalis, y a la serie de antologías neolatinas que los acogen (adaptando el soneto francés) en las minuciosas y precisas notas de R. Cacho Casal (2012: passim). Por cierto, que la versión que ofrece del epigrama de Natalis, recogida por él de las tardías Delitiae CC. italorum poetarum (1608) está falto de un dístico del que yo reproduzco. Ofrece a cambio una cuidada traducción española del epigrama (Cacho Casal, 2012: 192-193). Véase para la «idea generadora de los numerosos y variados tratamientos poéticos de las ruinas entre los neolatinos» en sus conexiones con el mundo clásico, F. J. Talavera Esteso (1991: 289-300). 
ruina presente / gloria pasada», que incluye la restricción al Tibre como particular contraposición «entre la caducidad mortal de todo el engaño humano y la pervivencia incólume de todo lo natural e inhumano», es también la del epigrama: desde los dos sentidos del término Roma, que se desprenden solo de su paradójica repetición en el mismo verso, con función gramatical y lógica distinta, «a la percepción del ordenamiento afín de todos los demás connotadores» (Ferraté, 1968: 187-191). Lo significativo es cómo Quevedo ha eliminado los referentes diversificadores a la Fortuna y a la gloria vencida de la Roma victric, acentuando, por el contrario, la idea del tiempo corrosivo y de la muerte: la antropomórfica visión de las ruinas como tumba y cadáver y el plañidero discurrir del Tibre ante la sepultura de lo que fue ciudad ${ }^{38}$.

Considero relevante comparar el soneto de Quevedo con otro de Luis Martín de la Plaza ligado también estrechamente a los dípticos de Vitalis:

\section{A Roma}

Peregrino que en medio della, a tiento buscas a Roma, y de la ya señora del orbe no hallas rastro: mira y llora de sus muros por tierra el fundamento.

Arco, termas, teatros, cuyo asiento cubre yerba, esto es Roma. ¿Ves ahora cómo aun muerta respira vencedora las amenazas de su antiguo aliento?

38 A. R. Alonso Hernández (1982-1983) ha puesto en relación los sonetos de Quevedo y Du Bellay e indica que «en una primera apreciación salta a la vista la similitud tanto en la paradoja del inicio - el buscar y no hallar a Roma en Roma, con repetición del término cuatro vecescuanto en la paradoja final - lo firme (la ciudad) se derrumba, lo fugitivo (el río) permanece-, que el poeta español debió encontrar ya en el epigrama latino, ya en el soneto francés, ya en ambos». Pero el epigrama de Vitalis y el soneto de Du Bellay se inician con un típico "vocativo de apelación», mientras en el de Quevedo «se nos presenta una suerte de inicio ex abrupto donde lo que interesa es descubrir o poner de relieve una situación más bien que configurar un tipo de interlocutor»; en aquellos la presentación del Tíber «es un elemento añadido a la secuencia precedente sólo en atención al sostenimiento de la sentencia final, en la que habrán de confrontarse las nociones de firmeza y fugacidad», mientras que en éste el río «culmina, aportando un vivo testimonio sonoro, la denotación de la metamorfosis esencial operada en Roma (la ciudad en sepultura)»; y no da lugar a «un tema englobante como el de la Fortuna y el tiempo». Quevedo, en conclusión, «persiste desde el inicio hasta el final en la reflexión del caso particular» planteado a partir de la infructuosa búsqueda de Roma en Roma, y en su soneto no solo encontraron eco «las ruinas patéticas y grandiosas de Vitalis y Du Bellay, sino las expresiones paradójicas con que comienzan y terminan ambos autores, imágenes de contradicción que hallaron nuevo cauce creativo a partir de una experiencia diferente». Lo más discutible de esta interpretación radica, a mi modo de ver, en el énfasis puesto al contraponer una actitud «descriptivo-reflexiva» a otra «vivencial-sentimental» y en poner a cuenta de la «identidad lírica de Quevedo» hasta «la muerte del símbolo amado»: una ingenua y muy improbable pasión por la idea de la Roma aeterna. 
Triunfó del mundo, y porque no quedara algo en él por vencer, venciose y yace, quedando el Tibre que su gloria hereda.

De la Fortuna en el poder repara: aquella que era firme se deshace, $\mathrm{y}$ aqueste, que se mueve, firme queda ${ }^{39}$.

Luis Martín de Plaza centra el soneto en el doblete conceptual victa-victri, mantiene a la Fortuna como fuerza activa cuyo poder explica la divergencia entre la firmeza deshecha y la movilidad firme, y asigna al Tibre la calidad de signo nominal que resta de la Roma gloriosa. No cabe adaptación más imantada por el atractivo retorico del epigrama de Vitalis. Nada del reflejo de un destino humano en la Roma desconocida que el peregrino - transeúnte ahora en su solo significado literal- llora en un primer momento, creyéndola deshecha, cuando «aun muerta respira vencedora». Llanto inmotivado donde no existe la tragedia ni por tanto, en correspondencia a la desaparecida humanización de las ruinas como cadáver, el resonare sobrenatural y elegíaco con que su corporeidad detenida inducía al pánico $-\mathrm{y}$ neopetrarquista - disolverse en lágrimas del Tibre. Lo que ha atraído como innovación es el sentido del límite impreciso en que lo natural conquista la ordenada e individualizadora disposición de la obra humana preludiando la metamorfosis final, en esa enumeración apositiva, con que se desarrolla el «haec sunt Roma» de Vitalis, donde el difuso recuerdo del Superbi colli permite ajustar la descriptio a un sistema de representación fragmentaria de las ruinas «cuyo asiento / cubre yerba».

En el libro que estoy comentando uno de los más difíciles ejercicios de síntesis aclaratoria tienen como objeto las ruinas en la poesía de Quevedo, por sí solas objeto de una tan rica como sugerente bibliografía ${ }^{40}$. Corre a cargo de

${ }^{39}$ Ya lo analicé en relación al de Quevedo en mis Notas (1981: 388-390), ahora ampliamente superadas por el análisis que bajo el título «Roma y las ruinas de la memoria» realiza el mejor estudioso de las silvas quevedianas, R. Cacho Casal (2012: 185-227).

${ }^{40} \mathrm{La}$ dificultad de llegar a conclusiones apodícticas y definitivas le ha mostrado, a propósito del soneto de Quevedo, M. Gai, quien vuelve a hacer un análisis comparativo esta vez a tres bandas: Vitalis-Du Bellay-Quevedo. Teniendo como referente la Agudeza y arte de ingenio de Gracián, opina que «el afán de novedad y maravilla en el que se empeña el conceptismo operando precisamente con elementos ya consagrados» se convierte en extremo desafío en el caso de una casi-traducción. «Sirven de encuadre — sintetiza - al soneto de Quevedo dos conceptos, encerrados cada uno en un dístico (vv. 1-2 y 13-14). Ambos determinan, en diverso grado, la estructura semántica de la composición. De manera distinta puede afirmarse con Gracián que la "dificultad del reparo" se da porque el "sujeto sobre quien se discute y pondera" — Romaaparece escindido; sus distintos atributos son separados y convertidos unos en circunstancia del otro y se suscita además discordancia entre ellos al predicarse una ausencia. El fundamento que da luego razón a la dificultad planteada en el primer dístico ocupa el resto de los cuartetos; en ese espacio se contraponen los términos correspondientes a una y otra Roma "careándose" el 
Adrián J. Sáez, quien elenca el corpus del motivo quevediano en tres sonetos («Enseña cómo todas las cosas avisan de la muerte», «A Roma sepultada en sus ruinas» y «A la huerta de Lerma, favorecida y ocupada muchas veces del señor rey don Felipe III y olvidada hoy de igual concurso»), en las silvas «Roma antigua y moderna» $\mathrm{y}$ «A los huesos de un rey que se hallaron en un sepulcro ignorándose, y se conoció por los pedazos de una corona» y en el comienzo «Funeral a los huesos de una fortaleza que gritan mudos desengaños», más otras trazas en el poema «Ruina de Roma por consentir robos de los gobernadores de sus provincias»; un corpus que «se reparte equilibradamente entre El Parnaso español (1648, con los tres sonetos y el romance) y Las tres musas últimas castellanas (1670), con las dos silvas y el último poemita» (p. 158). Tras establecer la posible cronología, en el arco temporal que va de 1615 a 1635, y el sustento vario desde la visita a Roma (1617) «a los posibles estímulos de estampas, guías y vedute de ciudades», y sintetizar de forma segura la «búsqueda de escorzos de originalidad» en una amplia síntesis de los posibles modelos, donde adquieren relevancia, por ejemplo, las exhaustivas aportaciones de Cacho Casal, aprecia el «potencial simbólico» en la variedad conseguida de tratamientos, de modo que en su panorámica pretende adoptar una doble perspectiva: «el manejo de la tradición y su importante dimensión artística». Establece de esta forma «tres dimensiones artísticas de interés»: 1) «Las ruinas valen como emblema de la disputa entre ars y natura», justamente porque el encanto de las ruinas consiste -en palabras de Simmel- en que «presentan una obra humana como si fuera obra de la naturaleza». 2) Se maneja un concepto artístico que abraza fundamentalmente la arquitectura y abarca igualmente algo del ars topiaria (jardines) y hasta estatuas, medallas y otros restos arqueológicos que dan mucho juego ecfrástico. 3) Representa la fuerza de la poesía «como monumenta ingenii que supera a las artes plásticas en un paragone por la preservación de la memoria (inmortalidad vs caducidad)» (pp. 160-161).

presente con el pasado, explicación desarrollada que se sintetiza en la primera mitad del ultimo dístico (v. 13), donde mediante un artificio conceptuoso se reúne la respuesta al enigma inicial. En el dístico final aparecen condensados todos los elementos del soneto, al incluirse en su segundo compás, los significados generados por la aparición del Tíber en el poema. A partir del caso expuesto - la motivadora contigüidad de Roma y el Tíber - se forma una paradoja duplicada, "trocándoles los efectos y atributos a dos sujetos contrarios" (Disc. xxIv). En la multiplicación de tan "relevante contrariedad" la disonancia doblada desemboca en consonancia, pues el segundo grado de la paradoja - "monstruo de la verdad" (Disc. xxIII) — no hace sino confirmar el paso primero, al establecer "que lo que permanece y existe no es sino el continuo fluir de la temporalidad" [...]. Ambos dísticos nos hacen reconocer la evidencia de la oposición de los iguales y la igualdad de los opuestos, revelando, mediante procedimientos distintos, lo mismo: la ruptura de la identidad» (Gai, 1986: 210-211). 
Bajo el lema Hispania quanta fuit se analizan la «ruinas patrias» de Quevedo empezando por «Miré los muros de la patria mía», verso que encierra ya la complejidad alusiva del soneto, donde «patria» parece admitir tanto «un sentido identitario-nacional (político)» como otro corográfico (de ciudad). Desde un inicial panorama de desolación general «se avanza en un movimiento progresivo que comprende la salida al campo (vv. 5-8), la entrada en la casa (vv. 9-10) y el propio personaje poético con su báculo y su espada» (vv. 11-14). Se trataría de «una estampa de gran visualidad» con dos fases diferenciadas, en un diseño de factura similar a ciertos epigramas de la Antología palatina, que tan bien conocía Quevedo ${ }^{41}$. El soneto $A$ la huerta del duque de Lerma comparte «la clave visual de principio a fin, de acuerdo a un diseño circular que encierra una comparación con su enseñanza aneja», tanto en la contraposición del pasado glorioso como en la lección moral sobre la caída de los poderosos, para concluir «con una invocación patética a la arquitectura» (vv. 12-14), en ambivalente paralelaje con el ars topiaria, que da lugar a las ruinas desengañadas de ambas. Entre estos poemas se situarían la silva $A$ los huesos de un rey y el romance «Funeral a los huesos de una fortaleza»: «el

${ }^{41}$ Como se indica en el que considero el mejor estudio del soneto de Quevedo, «para expresar la percepción de la fugacidad de lo visible se ha valido de unos cauces que encontraba fundamentalmente en la tradición clásica». El paraje desolado en su conjunto nos lleva a Lucano (v, 24-29) con «muros semidestruidos, campos cubiertos de zarzas sin manos que los cultiven»; además Propercio y Ovidio conforman los paisajes desolados, sin que en su pintura falten ecos horacianos. «El poeta establece un viaje en el soneto: de la ciudad, oppidum, sale a los campos de los alrededores para regresar a la casa. A la ciudad dedica el primer cuarteto; al campo, el segundo: a la casa propia, los dos tercetos». El primer cuarteto, centrado en la decadencia de la ciudad fortificada, remite a la Troya de Ovidio (Heroidas, I, v, 53-56) y a la Roma de Propercio $(\mathrm{IV}, 1)$ donde se canta a la primitiva localización de Roma «acaso con nostalgia de un mundo pastoril frente a la complejidad de la urbe imperial». Motivos a su vez recreados por humanistas como Eneas Silvio Piccolomini en De Roma o Christoforo Landino en De Roma fere diruta. En el segundo cuarteto, la descripción de los alrededores de la ciudad nos sitúa en antítesis al viejo tópico de laudes de estirpe clásica. Es el tópico vuelto al revés de la alabanza de Italia en Virgilio (Georgicas, II, 156-176), Horacio (Odas, I, 7, vv. 1-20) y Propercio (Carmina, III, 22), con amplísima descendencia en la lírica neolatina, desde Petrarca a Giovanni Cotta. En los tercetos el poeta regresa a su casa y se fija en dos objetos con valor metonímico: el báculo y la espada, ambos con signo de derrota. En ellos laten unos versos horacianos y el cuadro de Juvenal en cuya sátira III el poeta nos dice que en Roma no se puede vivir. Parece, en definitiva, que «aquí encontramos la vieja técnica de los exempla $[. .$.$] el poeta ha mirado y ha visto cómo todas las$ cosas avisan de la muerte». Pero para plasmar tan honda desolación, verdadera meditatio mortis, «se ha valido no solo de su maestría lingüística, sino, además, de los ricos mineros de la tradición literaria» (Ramajo Caño, 1995: 529-544). Véase asimismo la innovadora lectura de R. Cacho Casal en el apartado «Du Bellay y Quevedo: del soneto a la silva», que también tiene en cuenta para su contraste el de Luis Martín de la Plaza: «Quevedo — concluye—, lleva a cabo una profunda regresión en el tiempo activando los mecanismos de la memoria literaria [...] generando de este modo una lectura arqueológica de la tradición poética» (2012: 186-197). Y, en general, del mismo estudioso de Quevedo (Cacho Casal, 2009: passim). 
primero es una perfecta meditatio mortis a partir de un sepulcro, y el segundo tiene una dimensión amorosa». Probablemente «por la cercanía y el conocimiento de primera mano, la descripción de las Torres de Toray conforman el ejemplo de pintura de ruinas más detallado en Quevedo»: desde el arranque se da una comparación tácita con el pasado «de un castillo ya difunto» que en el presente de la composición «ha pasado a ser un auténtico locus horridus marcado por la muerte». En cuanto a la silva A los huesos de un rey, las ruinas son «puramente metafóricas» y «es un poema estructurado de acuerdo al patrón anillado de écfrasis, comentario y nueva écfrasis tan del gusto de Quevedo, que se puede relacionar con algún ejemplo de la pintura de vanitas» (pp. 161-169).

En Ipsa ruina docet: los avisos de Roma se estudian el soneto y la silva con la que Quevedo «recrea una prestigiosa variante del motivo» introduciendo un doble «diálogo con el legado clásico y el humanismo, así como introducir la mirada arqueológica». El soneto y le silva están estrechamente conectados, de forma que el primero «parece una versión en miniatura» del segundo: «Si bien hay notas de política y religión de interés (desde el "peregrino" del soneto hasta la apoteosis final de la silva), ambos poemas se enfrentan al interés arqueológico por los vestigios de Roma y a las estrategias urbanísticas de los distintos papas que - cada uno a su manera - han ido borrando huellas tanto de la gloria romana como de la cultura clásica». Como consecuencia apenas si hay restos, y la «antanaclasis inicial» es clara: la búsqueda de Roma (la fama) en Roma (los vestigios) del soneto, muestra a la perfección la función mediadora de las ruinas. En la silva, Quevedo ofrece «descripciones detalladas sobre la construcción y la caída de Roma (vv. 15-26 y 50-77) así como para introducir una reflexión adicional sobre las estatuas (vv. 78-110)», motivo este de paralelo origen neolatino. El excurso sobre las estatuillas, que funciona como conclusión del «deterioro irreversible de la ciudad antes de la resurrección cristiana» es de un ajustado equilibrio explicativo que conecta finalmente con la explicación comprehensiva de Cacho Casal, que ve en la silva además del diálogo arqueológico («una lectura barroca del Renacimiento») el ejercicio de «reconstrucción poética de la cultura clásica»: frente a la arquitectura y la escultura, que corren peligro de romperse en mil pedazos se defiende la fuerza de la poesía en una variación del tópico exegi monumentum aere perennius (pp. 169-175) ${ }^{42}$.

42 En un estudio que extrañamente no ha sido atendido por Cacho Casal, M. Ruiz Sánchez estructura la silva quevediana en tres secciones: la transformación de la Roma primitiva en imperio, el tema de las ruinas y la inmortalidad de Roma. Quevedo sigue, al igual que Du Bellay, el modelo properciano de evocación del mundo idílico que da paso a las conquistas romanas. La transición se produce a través de la imagen del río Tíber, expresando por sinécdoques fluviales el avance de la conquista. En el v. 50 empieza una nueva sección que sigue en su 
Como síntesis clarificadora de los distintos sentidos y funciones con que Quevedo «cumple a su manera con los requisitos de la poética de ruinas, en una exploración que apuesta por la experimentación de todas las posibilidades de la receta», determina cinco rasgos mayores:

1) La competición con los modelos en un ejercicio de aguda imitación compuesta.

2) La doble dicción de la contemplación y la visita autobiográfica.

3) La potencia simbólica de las escenas.

4) La fuerza visual de posible relación artística.

5) La variedad de elementos y formas conjugadas.

«Y es que las ruinas de Quevedo van de las imágenes generales (la patria) a modelos concretos (la huerta, Roma, las torres), pero los cuadros poéticos quevedianos no son copia directa de modelos antiguos, porque apuntan más bien a una reconstitución ideal que tiene mucho que ver con grabados y pinturas. De hecho, la clave mayor de la galería de ruinas de Quevedo es la visualidad, que se marca mediante la evidentia (con deícticos y verbos vivendi) y puede comprender pequeños ejemplos de écfrasis cruzados con modelos cercanos (las pinturas de paisaje de ruinas). Más allá, Quevedo se complace en trocar diversas disciplinas artísticas (arquitectura, escultura y topiaria) que le

desarrollo elegíaco el contraste entre el pasado glorioso y las ruinas presentes. La atención del poeta pasa de la arquitectura a la escultura y de esta a las tumbas. Los versos 123-146 tratan de la decadencia de Roma y de los peligros que ha tenido que arrostrar para sobrevivir. La última sección corresponde a los versos 147-180 y se refiere a un renacimiento que comienza expresándose con la metáfora del fénix, en enlace sutil con las imágenes del fuego dominantes en la segunda parte, mediante ecos verbales, que acentúan dicha relación. De esta manera la silva en su sucesión de imágenes traza un movimiento circular que, simplificando, se expresaría así: Roma primitiva (A), Roma imperial (B), Ruinas (arquitectura) C, Ruinas (escultura) C, Peligros para la supervivencia de Roma (B), Roma espiritual y eterna (A).

En sus versos Quevedo acentúa el tono de vanitas, de modo que las ruinas desvelan lo esencial de las grandezas pasadas a manera de cómo el cadáver revela la inanidad de las realidades humanas. La etapa final de la historia de Roma enlaza formalmente en Quevedo y Du Bellay con la historia primitiva. Pero en el poeta español las figuras de los fundadores de Roma tienen connotaciones fuertemente negativas, mientras que en Du Bellay las implicaciones negativas y el tema del titanismo se reserva para las épocas de crecimiento y esplendor. Forma parte de un contraste entre la pequeñez y la rudeza de los orígenes y el esplendor de la gran Roma; contraste inverso al de la sección central. Roma se verá reina del mundo y del cielo (como en ciertos poemas neolatinos) triunfando así del tiempo. En cambio, en Du Bellay está sometida a él. Tanto el poema francés como los neolatinos están presididos por la fórmula del paralelismo; en Du Bellay y Quevedo el movimiento es circular, con el regreso a un punto de partida (2000: especialmente 471-491). Otras matizaciones de interés se hallarán en A. Rey (1997: 189-211), E. Molina Fernández (2005: 47-65) y L. Schwartz (2014: 299-320), entre los elencados sobre las ruinas quevedianas en la bibliografía final. 
lleva a una querelle entre las artes, que presenta como ganadora a la poesía en la custodia de la memoria clásica y asimismo da nuevo vigor a la advertencia moral aneja» (p. 176) ${ }^{43}$.

Quevedo es un perfecto referente para volver en mi discurso al sentido de los descubrimientos de las ruinas que había iniciado con el Petrarca del Carmen metricum ${ }^{44}$. De no menor entidad es el segundo de esos grandes descubrimientos para el cual literatura y arte desplazaron el patetismo y la idea de $v a$ nitas a una más compleja valorativa desde la vivificación de las ruinas romanas. No se puede estar de acuerdo con aquellos estudiosos que desde J. Bialostocki han puesto en relación la expresión patética con las ruinas de Roma. En algunos casos por remontar como eco primigenio de esa actitud a la elegia de Hildebert de Lavardin fechable en el siglo XII; en otras por reducir al efecto del famoso soneto de Du Bellay el alcance de expresión patética, cuando ya el motivo lleva muchos decenios de andadura plástica y exegética. Cabría enderezar el nuevo descubrimiento de las ruinas romanas a una obra magna y difundidísima, la Hypnerotomachia Poliphili de Francesco Colonna, en la cual se muestra «una passione quasi mostruosa per l'antichità romana». Vagando, al principio de la obra, Polifilo contempla el espectáculo de las ruinas («Di statue ingente fracture, truncate molti [...]. Aquaducti et quasi infiniti altri

${ }^{43}$ Quevedo evita, naturalmente, la imagen multiplicada y vulgarizada de la Roma cristiana en una función como la que muestra el condensado cliché que introduce Cervantes en El licenciado Vidriera: «Se partió a Roma, reina de las ciudades y señora del mundo. Visitó sus templos, adoró sus reliquias y admiró su grandeza; y así como por las uñas del león se viene en conocimiento de su grandeza y ferocidad, así él sacó la de Roma por sus despedazados mármoles, medias y enteras estatuas, por sus arcos rotos y derribadas termas, por sus magníficos pórticos y anfiteatros grandes, por su famoso y santo río, que siempre lleva sus márgenes de aguas y las beatifica con las infinitas reliquias de cuerpos de mártires que en ellas tuvieron sepultura» (Novelas ejemplares, II, 1986, p. 111). Un conglomerado que amalgama para la laudario urbis dos términos aparentemente contradictorios y que podrá modelar, en sus desplazamientos, la visión de otras ruinas ilustres. Como ocurre con la contundencia del cierre, casi siempre depreciado estéticamente, de la Canción a las ruinas de Itálica de Rodrigo Caro, al incorporar las «reliquias bellas» del mártir Geroncio. Para la verdadera laudatio urbis de Cervantes y su complejidad, recordando que es en el Persiles donde termina la peregrinatio de sus protagonistas, y el instante contemplativo se acompaña con la condonación que la voz del autor-peregrino hace del ataque en un soneto-pasquín a la Roma papal, véase mi estudio (Lara Garrido, 1999c: 173-185).

${ }^{44}$ Con el ejemplo de Roma reaparece en numerosas ocasiones y con distinto grado de elaboración el sentido de fortuna labilis. Con un intencionado desplazamiento del opósito firme / fugitivo al tradicional de la Fortuna se presenta en esta alegorizante meditación anónima, con fuerte carga admonitoria: «Favor, privanza, imperio y grande asiento, / bien como espuma crece y se deshace: / lo bajo el corazón no satisface / lo alto ha de caer, que va violento. / ¿No veis de Roma el alto fundamento, / la fuerza y el poder que puede y hace? / Cayó lo alto que para eso nace, / lo bajo duró más que es el cimiento. / Es el cimiento ver mi baja hechura, / y en esto bajo estoy seguro y fuerte; / desotra apenas queda la figura. / No os lleve en alto vuestra dulce suerte. / ¡Ay no os engolosine esa dulzura! / ¡Tened tras dulce vida amarga muerte!» (FoulchéDelbosc, 1908: 515-516). 
fragmenti»), y esta incomparable visión conformará el fondo del relato, porque en medio de los restos de la antigua Roma soñará en revivir su grandeza: «Lo spettacolo stupefacente dei monumenti romani - escribe L. Donati-e delle loro rovine, i ricordi d'ogni parte pervenutici della grandeza antica che tanto hanno acceso la fantasia di Polifilo sono assai bene riassunti nell'elegia dell'Anonimo diretta al lettore: Hic sunt pyramides thermae ingentesque colossì (Donati, 1975: 37-64) ${ }^{45}$.

Son las ilustraciones de la Hypnerotomachia las que inician la andadura hacia lo que a la larga será otro descubrimiento esencial, que ya no es tanto de la mirada ni de la indagación reflexiva cuando de la imaginación. Se trata de desprender el motivo de una figuración mimética y por consiguiente de unas ruinas reales. Lo que se traduce en la disponibilidad de un imaginario cuyos figurantes pueden encartarse hacia distintas nominaciones prestigiadas de la cultura humanística, de las que incluso puede no haber resistido el paso del tiempo ninguna huella material ${ }^{46}$. Acaso se representa mejor este descubrimiento desde la plástica, pues, como oportunamente recuerda J. Starobinski (1964: 179), «los pintores han imaginado muy pronto ruinas para elaborar una decoración intermedia entre las estructuras ficticias y el mundo natural, entre el palacio y la roca [...]. Un vestigio del pasado ennoblece la naturaleza, convierte una vista vulgar en un paisaje heroico o idílico» ${ }^{47}$. Terminará por crearse el género de la veduta de ruinas, que tuvo en Pannini a su genial inventor con los paisajes-retratos, y que alcanzará en Piranesi su culminación. Este supo dotar a las representaciones de una «majestuosidad espectral [...] un universo desproporcionado en el que el monumento, signo de un destino, rebasa infinitamente la figura humana» ${ }^{48}$. Por lo que respecta a la pintura, al igual que

\footnotetext{
45 En un manuscrito de la Biblioteca Casanatense se encuentra, precedido de dos sonetos anónimos, un poemita de 133 terzine, imitación ya del Polifilo: «Il monumento che forse più d'ogni altro s'impose all'ammirazione di Polifilo è il Colosseo [...] Polifilo aveva visto nel Colosseo il quarto ordine, ma esso non aveva archi né colonne, inoltre alla sua epoca era coperto da erbacce, perciò lo describe e disegna come un geometrico giardino pensile, pur sempre facente parte del complesivo arquitettornico [...]. Nella lunga descrizione del monumento abbiamo preso qualche frase che desse un'idea della sua costituzione architettonica, ma è da tener presente che gli vi pose le sede di Venere uscente dalle acque, popolato il luogo da schiere di Ninfe nude e vestite carolanti e cantanti [...]. È questo suo modo di trasfigurar tutto che aveva visto ed ammirato in Roma per introdurlo nella sua narrazione» (pp. 52-58). El espectáculo de los monumentos romanos y de sus ruinas están subsumidos en la elegía del anónimo dirigida al lector «Hic sunt pyramides thermae ingentes colossi. Ac obeliscorum forma uetusta patet [...] (p. 59).

46 Véase la clásica exposición de C. Huelsen (1910-1911: 161-176).

47 Véase el fundamental ensayo de A. Hui (2016).

48 E. Orozco Díaz (1947: 137). La consideración de las ruinas establece en su poética un elemento esencial de la episteme y la psicología barrocas: el sentido de la memoria (Lavin, 1992: passim). Para España resultan definitivos los estudios sobre el ars memorativa que ha llevado a cabo A. Egido, especialmente (1994: 93-135; 1996: 133-175; 2004: 51-72). En un último
} 
ocurre en la poesía, el motivo «que como cuadro de moda se extiende por Europa tiene su origen en lo italiano» (Orozco Díaz, 1947: 138).

El movimiento de disociación progresiva entre imágenes del natural y figuraciones marcadas por la artificialidad (en especial los obeliscos) y libre inventiva resulta también patente. Y se podría enblematizar comparando el Arco de Tito de Juan Bautista Martínez del Mazo, que «parece una simple vista de la ruina arqueológica contemplada desde la Vía Sacra y teniendo como fondo las tapias de los Orti Farnesiani», con la Salida de Eneas de Cartago de Beníto Manuel Agüero, «donde las ruinas de un templo a la izquierda están utilizadas como repoussoir para lanzar la vista hacia el puerto y la marina del plano de fondo ${ }^{49}$. En esos espacios innominados, y al igual que ocurrirá en el tratamiento poético, es donde el ritmo cósmico de las metamorfosis aumenta posibilidades para su presencia y aun desmesura, de manera que «el motivo de las ruinas en conexión con una vegetación floreciente tiene una gran importancia iconográfica en la pintura y sobre todo en la pintura paisajística». Ejemplo extremo es el cuadro de Abraham Mignon, en el Museo Narodowe de Varsovia, que describe con insustituible eficacia J. Bialostocki, dando relieve al entramado de símbolos a la vez de vanitas y mutabilidad natural: «Representa el fragmento de un paisaje muy aumentado, como si fuera visto a través de un teleobjetivo; entre las piedras, hojas y maleza que hay en un pequeño charco de agua, entre unas ruinas visibles solo en parte; bajo las frondosas floras, la hierba y los matorrales, se mueven las mariposas, los escarabajos, las hormigas, las ranas, los pájaros, las serpientes y los caracoles. En este reino verde y

y amplio recorrido por las Novelas ejemplares concluye que si bien Erasmo, con un «claro desarrollo de la mnemotécnica tradicional de la retórica» y «tras las huellas de Quintiliano, Cicerón y la Ad Herennium propone objetos y lugares para albergar en ellos resultados de recuerdos», Cervantes en cambio «huye de esa tradición retórica para hacer novela. Vale decir, para que la memoria discurra por los complejos canales del alma humana, sirva para comunicarse y desemboque en el gran cauce que la convierten en cauce sustancial de la creación literaria» (Egido, 2018: 324-325).

${ }^{49}$ Recurro a la comparación realizada por A. Rodríguez de Ceballos, «Los fondos arquitectónicos de la pintura del Siglo de Oro», en AA. VV. (1991: 234-235). Un excelente recorrido presentó ya A. Ávila (1988). Aunque la aplicación filográfica del motivo de las ruinas estaba generalmente limitado a una evocación in praesentia, para huir del tópico recurso exclusivo en la proverbial ecuación establecida entre el amor acabado y Troya, Salazar y Torres (1601: 56) acudió a las ruinas figuradas en la pintura como una singular mediación imaginaria. El supuesto cuadro cumple las mismas funciones que sostienen las ruinas directamente contempladas: A Cintia, que mirando unos lienzos la llevó la atención uno en que estaba pintada la ruina de Troya: «Cintia, ¿qué miras? ¿El engaño griego / que atrevida mintió bárbara mano? / Que luego te llevase lo inhumano / que la ruina te inclinase luego. / Mejore estragos el vendado ciego / aumentando violencias al tirano, / y de tu vista el rayo soberano / arda el Asia otra vez en mejor fuego. / Mas si de ver incendios solo trata, / y engaños, Cintia hermosa, tu despecho, / no mires, no, de Troya los despojos; / vuelve a mi fe, donde verás, ingrata, / las cenizas que aun arden en mi pecho, / los engaños que aún viven en tus ojos». 
húmedo las hormigas se ceban en el esqueleto de un pájaro muerto; no muy lejos hay otro pájaro muerto, con las patas rígidas y estiradas; masas de pequeños insectos buscan su botín; de entre las hojas y flores va saliendo una serpiente. Sobre este campo de batalla en el que se desarrolla una lucha sin consideración de todos contra todos [...] ha sido concebido un proceso incontenible de transformación de la vida» $(1973: 207-209)^{50}$.

Pero al mismo tiempo que esa metamorfosis multiplicada habría que subrayar el uso en «arquitecturas y ruinas pastoriles» de un término que nos retrotrae al paradigma de la Hypnerotomachia por su incidencia lateral, pero no improbable, en determinados elementos de las Soledades gongorinas. Ya desde el inicio aparece el paradigma adjetival («rayó el verde obelisco de la choza») ejemplo de otros en que Góngora hace «aflorar en la superficie verbal, bajo la forma de una peculiar adjetivación, anómala fuera del texto, y que se vuelve norma dentro de él, un permanente diálogo o cotejo entre la vegetación y la arquitectura $\rangle^{51}$. Insistamos - escribe poco después- en que la serie de los términos tratados como sinónimos en nuestro paradigma, remiten a un espacio no solo urbano sino a menudo palaciego y monumental caracterizado por el artificio, la riqueza, y en ocasiones por la ostentación, la altura extremada o sublime, la forma fantasiosa y el cariz exótico». Con su última

\footnotetext{
${ }^{50}$ Es obvio el conjunto encadenado de cambios como una especie de garantía de inmortalidad a través de un ritmo cósmico donde la muerte y la metamorfosis son fenómenos cotidianos a los que se podría aplicar la reflexión clásica de R. Barthes (1967: pp. 132-133): «Morir aquí es percibir la vida [...]. La muerte es a la vez fácil y resistente, está en todas partes y huye [...]. Porque quizá sea eso el Barroco, como el tormento de una finalidad en la profusión». Un emblema categórico lo representaría el mismo rey de España, Felipe iv, cuya contribución a las artes conjuntó, en expresivo proceso de selección, un soneto a la muerte y el dibujo a pluma de «un país con ruinas» (Orozco Díaz, 1947: 60-61).

${ }^{51}$ Por el contrario, la antropomorfización de las ruinas aparece con menos frecuencia y énfasis en la poesía barroca española. Un buen ejemplo de la misma se encuentra en Miguel Colodrero de Villalobos, que recurre con relativo ejercicio de variaciones a proyectar el diseño del motivo al ámbito natural, como término privilegiado de caducidad ( A la ruina de una palma, Moralizando la ruina de un laurel por un rayo). Colodrero es también autor de un soneto donde aflora la ecuación de metáforas entre la corporeidad del edificio y la arquitectura humana, con el recurso apelativo propio de la poesía epitáfica, la que conglomera un tertium que viene a identificar las ruinas con el cadáver: «Era el que ves postrado, caminante, / un monte reducido a pulimento, / un edificio digo, su cimiento / por más edades le juzgó constante. / Columnas tuvo, cada cual Atlante / de mucho lapidoso pavimento, / y ya por el más sólido elemento, / sin forma piedras ruedan elegante. / Si máquina tan fuerte, si tan dura, / no dura, se desliza y vuelve a nada, / por no mentir en lo perecedero, / ¿cómo presumes tanto de segura, / pirámide de tierra aunque animada? / Más dirás que el engaño es lisonjero» (1629: 44). Una secuencia de idéntico valor modal se encuentra en el Ms. 3988 de la Biblioteca Nacional de España, donde se reúnen un soneto A unas ruinas («Esas que preciosas canterías...») con otro A una rosa nacida en una calavera («Estrella de carmín que lisonjera...»), un madrigal $A$ un árbol nacido en un osario (que el copista aclara como «asunto no supuesto») y un romance $A$ una calavera (ff. 5r, 14r, 21r y 76r).
} 
aparición en la canción del joven protagonista en la Soledad segunda, el obelisco «marca un término posible de la peregrinación amorosa, un término funesto de la muerte por desesperación, y en esa medida puede remitirnos a uno de los antecedentes de este núcleo temático del poema». El vínculo entre obelisco y peregrino lo debe tal vez Góngora al Sueño de Polifilo. Y, de hecho, «aunque han pasado desapercibidas, son notables las coincidencias», como fascinante es el itinerario que M. Blanco traza para el conocimiento por parte de Góngora de las xilografías que acompañaban al texto de Francesco Colonna. «Al comienzo de la obra — subraya - la historia que nos es contada presenta algún punto de contacto con la Soledad primera, el primer lugar o teatro simbólico con que se topa el peregrino de amor en Colonna, después de haber sufrido la prueba de atravesar un horrido bosque (spantevole silva) es un ameno valle cerrado por el edificio que dominan el obelisco y la columna. El peregrino de Góngora, después de una dolorosa travesía como náufrago agarrado a una tabla y de la escapada de un monte fragoso y espinoso, se encuentra con otro edificio, un "templo de Palas" asimilado conceptuosamente a un "verde obelisco". Estimo que esta choza-albergue, "templo de Pales" es el simétrico reverso del "Templo de Fortuna" del Polifilo. A las maravillas de ambición y sutileza del ingenio artificioso, el sublime empeño de una arquitectura visionaria, se contrapone la exquisita constelación que forman en la choza pastoral, la inocencia, la sinceridad villana y ese "candor primero / que en las selvas contento / tienda al fresno le dio, al roble alimento", el no menos sublime candor de la Edad de Oro» (pp. 457-458) ${ }^{52}$.

Volviendo la mirada al volumen que reseño resulta de notable interés que se haya abandonado el examen exclusivo de los textos líricos y se dedique un capítulo a la presencia del motivo en el teatro, a través de la fortuna de un romance a las ruinas («Escollo armado de hiedra») de Luis Vélez de Guevara. Al asunto había dedicado ya una monografía D. Crivellari, cuyos aportes se sintetizan en su colaboración. En ese romance el locutor poético se dirige a un edificio en ruinas «recordando los tiempos pasados, su esplendor de antaño y reflexionando en definitiva sobre el topos del tempus fugit con un guiño final al tema amoroso» ${ }^{53}$. La composición gozó de cierta fama, como lo muestra su

52 La demostración, para mí convincente, que hace M. Blanco, exigiría más páginas de las que ahora, incidentalmente, puedo dedicarle. Pero concluyo con esta especie de síntesis metahistórica: «Desde la época helenística y hasta el iluminismo y la francmasonería, las creaciones más singulares de la civilización del Antiguo Egipto, pirámides, obeliscos, jeroglíficos y esfinges se prestaron a la perfección al oficio de depositarios y guardianes del misterio. Así el obelisco de Góngora se alza como guardián a la entrada en el mundo de las Soledades, un mundo para los iniciados en su idioma, pero también capaz de iniciarlos en él» (p. 460).

${ }^{53}$ Complementariamente, el engarce del motivo de las ruinas en un proceso argumental y argumentativo de meditatio mortis venía facilitado por su constitución como un referente 
inclusión en antologías poéticas y los positivos juicios de diversos ingenios. El propio Vélez empleó partes del romance para una glosa incluida en la comedia El privado perseguido. En ella puede notarse el importante papel que en su difusión desempeñó la música. Y por eso es de subrayar cómo el autor analiza los mecanismos de inserción de los fragmentos del romance en las obras que lo acogieron: la comedia cómica de Alarcón La culpa busca la pena y el agravio la vergüenza, la de Calderón El postrer duelo de España o las piezas de tipo religioso Los desagravios de Cristo de A. Cubillo de Aragón y Contra la verdad no hay fuerza de M. de Barrios. Resulta significativo cómo en diversas comedias la intercalación del romance repercute en la acción dramática: en Más la amistad que la sangre de Andrés Baeza subrayando «la anagnórisis de los protagonistas», y con «una sorprendente polifonía de significado, gracias a la presencia del coro» y los diversos efectos en comedias de Calderón (Hado y divisa de Leónido y Marfisa o El pintor de su deshonra) o de Antonio de Zamora (Amar es saber vencer y el arte contra el poder). Unos cambios de registro que van, en su versatilidad, desde la belleza femenina perdida a la persecución de los judíos o la firmeza de la mujer para defender su honor ${ }^{54}$.

nuclear de la poesía moral barroca. Su eslabonamiento preciso con otros referentes próximos, concertando un concepto complejo, se manifiesta de forma precisa en un soneto del antequerano Gerónimo de Porras. En él se discurre sucesivamente, marcándolo mediante variaciones de valor con función de señalamiento, por los ámbitos de la cultura (las ruinas), la naturaleza (la roca erosionada por el mar) y la vida humana (del esplendor de la «beldad» a la «fría ceniza»). Un circuito cerrado de significaciones organiza además el intercambio de los signos de la caducidad en transferencias cruzadas y —por ende- permutables: Al desengaño de la vida: «Repara en esta, un tiempo peregrina, / ya, Fabio desatada arquitectura, / y mira en mal compuesta sepultura / siendo fábrica ayer lo que hoy ruïna. / Mira esta roca que, del sol vecina, / a pedazos el mar, con lengua pura, / lamiendo su robusta contextura, / urna le constituye cristalina. / Contempla una beldad que al cierzo aleve / del tiempo en su hermosura reconoce / fría ceniza la que ardiente llama. / ¡Oh vida, vana sombra, soplo leve!, / no te ama aquel que cuerdo te conoce, / no te conoce aquel que ciego te ama» (1639: 13v).

${ }^{54}$ En el poema, como en muchos del Barroco tardío, el consecuente filográfico ha desaparecido. Véase, por el contrario, de qué forma se afianza en determinados textos de Salcedo Coronel, aplicándose de forma abrupta a la relación, como mediaciones simétricas, de ruinas y naturaleza: A las ruinas del anfiteatro de Capua: «Esta rüina que corona en vano / inútil yedra, con infausta gloria, / testigo un tiempo de infeliz victoria / oyó lisonjas del aplauso humano; / aquí, donde el arbitrio dio tirano, / rígido asunto a esclarecida historia, / apenas haya libre la memoria / breve luz de esplendor tan soberano. / Rígido arado ofende inadvertido / la excelsa magnitud cuya grandeza / idolatraron bárbaros errores. / Toda la edad lo trueca y el olvido, / ¿y quiero yo que dure la firmeza / de Lisi, más constante a sus rigores?»; Soneto: «Visten de horror en el diciembre helado / pálidas sombras la región del día / y coronado de la nieve fría / gime oprimido el monte levantado; / desnudo cede al Aquilón airado / el que fue de los prados alegría, / frondoso chopo que verter solía / hojas de mayo, cifras al cuidado; / abre las puertas con dorada llave / abril del año, y Febo restituye / al cielo, al monte, al árbol su hermosura. / ¡Cuán fácil muda la estación más grave / piadoso el tiempo y a mis voces huye / sin llevarse tras sí mi desventura!» (1649: 3r-v). 
Este punto de fuga propedéutico nos puede servir para reflexionar sobre dos términos documentales desatendidos en el estudio del motivo: la importancia de los textos musicados y la ausencia casi completa de determinados géneros que dieron generosa cabida al motivo de las ruinas. Por lo que hace a lo primero sería necesario acotar y recoger todos los textos poéticos de ruinas que fueron musicados. Me limitaré a poner de relieve el interés de un poema musicado del que solo tenemos la letra pero cuya condición de tal se nos remarca en el epígrafe. Me refiero al romance asonantado de Francisco Manuel de Meto Ruina argumentosa cuyo subtítulo reza «Puesto en música por el P. M. Felipe de la M. de D.». Como indica ese rótulo se trata del desarrollo de un argumento: el de unas torres que ya no son tales sino «cadáveres desnudos», iniciando el despliegue de un metaforismo funéreos que luego deja paso a las tragedias del tiempo, representado por la variación de formas desde la muerte cruenta en la guerra a la muerte natural por consunción y vejez:

Francisco Manuel de Melo

Ruina argumentosa. Puesto en música por el P. M. Felipe de la M. de D.

Cuatro o seis torres que fueron, cadáveres son desnudos del castillo de Mayorga soberbiamente difunto.

Cimenterio es el cimiento donde su esplendor compuso, que en las pruebas de gallardo se ensayó para caduco.

Lo que antes fue fortaleza a flaqueza hoy se redujo, la pólvora ardiente a polvos tan fríos como confusos.

Los lienzos de sus murallas son mortaja en vez de muros, sus bóvedas son sus huesas: él es el muerto y sepulcro.

Brilló en las sienes guirnalda de aquel escollo robusto, que hoy calavera enternece y le desengaña junto.

Sus colunas, sus almenas, sirvieron, con más estudio, de testimonio a su estrago que no a su pompa de anuncio. 
Si las losas fueran mieses, mármol naciera fecundo de capiteles que yacen sembrados por esos surcos.

Sonora alcándara era al dulcísimo mormurio de las aves, y es agora bruto caro de los brutos.

Tanta lástima le tiene cuanta emulación le tuvo el sol, viendo que del aire ya fue gala y hoy es luto.

Perdonáronle mil años el vaïvén y el trabuco de la guerra, no la guerra de los años importunos.

Resistiose a los estruendos, a los silencios no pudo, que horas blandas son más fieras que los fieros golpes duros.

Lima sorda de los días, lamiéndolo con minutos a dentelladas suaves sus tragedias le introdujo.

Sin proceso falló el tiempo, su jüez y su verdugo, que es crimen digno de muerte el haber vivido mucho.

Murió de achaque de altivo: dígalo el diadema rubio, pues ya no hay imperio sagrado contra estotro imperio rudo.

(ff. 60-61)

Pero la lírica musicada no pasa de ser el fragmento de un fragmento de cuanto nos queda por documentar, antes de cualquier asedio o encuadre, sobre las ruinas, en géneros concretos de carácter panorámico o narrativo. Valgan dos ejemplos que no me resisto a abordar. El primero es el de los llamados 


\section{libros de antigüedades o de elogios de ciudades ${ }^{55}$. Sirva como muestra signi- ficativa la apertura del poema Granada de Agustín Collado del Hierro, cuyo libro I se rotula, significativamente Antigüedades:}

\footnotetext{
${ }^{55}$ En ocasiones estos elogios, cuando son poemas breves en particular, transparentan la transferencia de los modelos clásicos de ruinas, incluido el Superbi colli. En sus Tablas poéticas introdujo F. Cascales, en este sentido, una excelente canción de Diego Beltrán Hidalgo a las ruinas de la ciudad de Cartagena, su patria: «Destrozos mudos que en lugar de lenguas / burlando al tiempo el cielo os ha dejado/ para contar al mundo vuestra historia, / cuyo soberbio muro derribado / pasadas honras y presentes menguas, / representan silencio a la memoria. / Viendo resuelta en ecos vuestra gloria, / suspensa el alma por su ejemplo, corta / con vuestro desengaño / la ahogadora cuerda de su engaño, / pues halla en tanto que contempla absorta / su misma desventura en vuestro daño / que el humano poder, honra y contento / por ser la vida corta / en sombra, sueño, humo, polvo y viento / Commiato: Canción, si a tu sujeto, que es dibujo / que muestra mi desdicha en sus agravios / el cielo la eterniza, / tus letras lenguas y tus versos labios / serán que siempre digan, si por dicha / tuviesen pechos, sabios, / donde llegó un placer y una desdicha» (1989: 244-245). Véase también sobre un poema de L. Mateu y Sanz, E. Julia (1941) y sobre el de Miñana acerca de Sagunto, los estudios de F. J. Pérez Durá (1993), J. M. Estellés y González (1993) y E. Rodríguez Cuadros (1993). De forma parcial quiero agregar partes de una inédita Silva anónima En consideración de las ruinas de Burgos: «[...] Era del día la estación del año, / era la ardiente, cuando / el que a los monstruos lúcidos del cielo, / rey de la luz, sus luces comunica; / del animal retrógrado encendido / caminaba a encender el truculento / al tiempo que perdido / de mi fortuna, en ondas solitarias / náufrago siempre en tormentoso suelo, / guiado de mi engaño / que aún me lleva a tentar regiones varias, / me dio florido asiento / verde margen de un río / al oído risueño, en vista blando: / miraba a un lado en áspero desvío / gigante sierra al cielo levantarse, / al otro dilatarse / de frondoso caudal campaña rica / y entre avarientas ramas / distantes, descubrir escasamente / deformes bultos de fatal rüina / torres un tiempo que de sus almenas, / con glorïosas llamas / farol era el favor resplandeciente / a la piedad errante o peregrina, / y a su afligida España / defensa firme si atalaya fuerte, / yacen ahora, ¡oh rabiosa saña!, / de voraz tiempo, de invidiosa suerte, / aun ruinas apenas, / y así trofeo suyo más glorïoso / pues miran a sus pies la gran cabeza / del invencible pueblo castellano, / y rica multitud de pueblo ufano / reducida a desierta y vil pobreza [...]. / Así, tristes memorias, / engendradas lloré de ajenas glorias, / mas tras discursos nunca bien llorados / los lagrimosos ojos / que de su humor borrados / abiertos los tenían más vecinos, / por los más apartados / dejé vagar un rato peregrino, / y al fin los detuvieron / los sagrados despojos / que cuna y tumba a las virtudes fueron. / La majestad postrada, / débil estatua de mortal grandeza / y de mi propia máquina oprimida / miré suspenso, y que la edad airada / de mi jurisdicción exenta deja; / las ciudades, los reinos vencedores / de su mano atrevida / fácil trofeo son, y la flaqueza / suplida al hombre en dones superiores / de ser mortal se queja. / " $\mathrm{OH}$-les dije — reliquias venerables, / mármoles generosos, / caídos sí, más no de honor desnudos! / Bien son vuestras ruinas lamentables, / mas perdonadme, os ruego, / si en ellos, inhumano, hallo sosiego, / pues dan a mis tormentos / sus lejos lastimosos / con elocuente ejemplo alivios mudos, / que si pueden lo firme, lo invencible / derribar y vencer tiempos violentos / también caerán mis hados vitoriosos!" / Dije, y dejando aquel lugar ameno / ya con beldad visible / de resplandor tocado matutino, / vergonzoso de hallar en mal ajeno / al propio mal templanza, / con corrida esperanza / di al sol espaldas, pasos al camino».

De las ruinas innominadas es ejemplo sobresaliente la siguiente Silva de Paulo Gonçalvez Andrade titulada Ruina de un suptuoso edificio: «Este, que a las edades obediente, / cadáver prodigioso, / en trozos a la tierra desparcido / si no en cenizas desatado al viento, / logra en la tierra formidable asiento, / donde piadosamente recibido / con trato, bien que pobre, generoso, / firme, si no decente, / entre la amiga hierba / eternizado túmulo conserva, / a sus perdidas glorias y
} 
Tiene Granada (corazón del mundo)

la Asia enfrente, a la siniestra mano

1'Africa, que en seno más profundo

la termina el Estrecho gaditano;

a la diestra la Europa y el segundo

orbe américo (a quien el Oceano

Antártico divide) forma solo

su occidental, su contrapuesto polo.

De su primera ya real cabeza

mediterráneas metas orientales

le pone el mar, extiende su grandeza

en sus términos más setentrionales.

$\mathrm{Su}$ antigüedad con la naturaleza

delicias / corteses, aunque bárbaras, caricias; / y las tenaces yedras / vistiendo nobles y abrazando graves / a las desnudas y extranjeras piedras, / con halagos suaves, / resignados en rústicos abrazos, / señas, si no de amor, de cortesía / repiten cada día, / a su desdicha indisolubles lazos, / a grandezas que yacen por el suelo, / si no arrimo, consuelo, / cobrando en cualquier suerte / temor la vida, adulación la muerte. // Este que conocerse deja apenas, / y en sí mismo escondido, / no se halla a sí, dentro de sí perdido, / un tiempo, de sí mismo remontado, / se vio de sus principios olvidado, / alto edificio fue cuyas almenas / con osados sacrílegos alientos, / en fe de sus cimientos / se fueron coronar a las estrellas / de lucidas centellas, / si no fue que arrogante / de cada almena fabricó un gigante / que, desmentidos hijos de la tierra, / dieron sobre sus hombros / al mundo todo asombros, / leyes al aire y a los cielos guerra. / El viento a su grandeza respetoso / registraba su aliento / y soberbio señor de todo el viento, / no se atrevió el viento a su reposo; / y tanto se excedía / que elevado y constante, / no sé si fulminado o fulminante, / sin alterar el imperial sosiego, / en el horrendo ensayo / soberbio parecía / que, superando el fuego, / mandaba el fuego y fulminaba el rayo. / Agora en pobre estado / de sí mismo se mira derribado, / y en mortal parasismo / vino a caer en sí desde sí mismo, / siendo el propio edificio / precipitado a un tiempo y precipicio. // Magnífico aparato le prestaron / mármoles griegos, pórfidos latinos, / primor de sus primores peregrinos; / los latinos y griegos envidiaron / que en cada adorno, en término sucinto / se incluyó Roma, se perdió Corinto; / viendo sus perfecciones / las envidias quedaron confusiones; / la proporción austera y regulada, / que la paciencia, entonces diligente, / al modelo reparte / alma infunde a la ciencia y ciencia al arte, / y el arte a sus designios aplicada / era prolija ya de concertada. / Y las colunas ricamente hermosas, / cansadas ya de puro artificiosas, / ya de puro cansadas abatidas / al poder de los años, / que a sus manos vencidas / no resistieron los postreros daños; / tierno vidro a sus brazos / hizo la edad los mármoles pedazos / que en trágicos fragmentos divididos / serán eternamente ejemplo mudo / de lo que el tiempo pudo, / donde, por sus desdichas conocidos, / caracteres serán despedazados / que dediquen su historia / a la inmortal memoria. // ¡Oh vos dos veces bienaventurados / frisas, cornisas, pórticos, columnas, / cuándo abatidos, cuándo levantados / único ejemplo de las dos fortunas, / glorioso objeto de comunes ojos / fuistes edades largas, / cuya hermosura entonces elegante / rémora fue del peregrino errante, / adonde a su cuidado, a su camino / dos alivios hallaba el peregrino! / Agora, a tantas lástimas atento, / en memorias amargas / en flébiles despojos, / halla el entendimiento / escala donde aprenda el escarmiento. / Felice, joh edificio!, / a los descuidos te formó la ciencia, / más harto, más felice, a la prudencia, / al deshacerte te hizo el precipicio: / felice te imagina / aun más que al nacimiento a la ruina, / que en ella construido, / Fénix de tus reliquias renacido, / para inmortal ejemplo / de tus reliquias considero un templo, / adonde, respetado y conocido, / el sacro desengaño / canonice sus créditos tu daño» (ff. 64v- 67r). 
contendiendo las eras, los anales

de perdurable ancianidad vestida

de los primeros siglos es medida [...]

Sus antiguas rudezas ilustrando

en elegantes obras excedía

a Demócrato griego, edificando

al Canopo la ilustre Alejandria.

Los macedonios montes igualando como al Ocaso, al Austro, al Mediodía, le ciñen el Olimpo, el Pindo, el Pelio o los de Ausonia a quien corona el Celio.

Y como el reino suyo ya perdido del tirano Hiarbias al estrago se llamó la ciudad de Elisa Dido Byrsa, Tiro después, y al fin Cartago, en vez del libio estadio dividido (montañas rodeando el viento vago), se nombró la ciudad della fundada Iliberia, Ilípula, Granada.

Los Fenices (que desde el Eritreo, el mar peregrinaron de occidente, por ver del grande sucesor de Alceo, las dos colunas que fijó altamente), los montes viendo, a quien mejor Perseo la faz mostrara de Medusa ardiente, que fue del libio funeral materia los muros construyeron de Iliberia [...]

$$
\text { (octavas 6-7 y 15-17) })^{56}
$$

\footnotetext{
56 Naturalmente, el repaso de las antigüedades granadinas imaginadas por Collado del Hierro conduce desde Egipto y Tiro a las evocaciones de todas las ruinas ilustres desde Troya a Roma («a Roma busca en Roma el peregrino / y solamente en relación admira / cómo de la antigua en la moderna espira») [octavas 23-28]. El conjunto de este libro I es en sí mismo un ejemplario de tópica sobre el poder devorador del tiempo («Oh breve flor que naces con la Aurora / y mueres con el Sol! / Tu acelerado curso (¡oh vida mortal!) cifró tu ejemplo, / el desengaño levantó tu templo») y el «glorioso esplendor de sus ruinas» [octavas 29-32] (Orozco Díaz, 1960: 180-181 y 211-213). Los «campos hoy al desengaño abiertos», donde «el viento airado libremente suena» conforman un multiplicado «vividor ejemplo» que «sombras habita de silencio mudo». Un conglomerado de piedras famosas que «memorizan formas de la suya eternas», venciendo a su «archivo» la perpetuidad misma del cedro (octavas 33-48):
}

De fausta noble ancianidad vestidas las piedras se ven hoy historiadas, que parecen del ciclo producidas para quedar en él eternizadas. 
El segundo es el de la poesía épica, género que por la obligada superfetación de lo descriptivo otorgó a las ruinas un espacio de privilegio. Escenarios y paisajes de ruinas contrapuntean buena parte de estos poemas, de forma que el análisis del motivo estará siempre incompleto mientras no se realice una obligada labor de campo. Para ejemplificar voy a detenerme en los más relevantes que se acogen a la andadura épica de El Bernardo de Balbuena. He aquí un pasaje significativo por expresar la inmortalidad de la poesía en contraste con las catástrofes del tiempo:

Así a los cielos ruego le suceda al vuelo heroico de mi corta pluma, que si hoy humilde y por el suelo queda mañana suba a ser de honor la espuma, y en lo alto ya de la voluble rueda, el tiempo ni la halle ni consuma; mas con su altiva voz tan hueca suene, que el mundo espante y sus regiones llene.

De todas las humanas invenciones, soberbias torres, máquinas, trofeos, bellos teatros, ricos panteones, altas colunas, graves mausoleos, anchos doriscos, sacros iliones, colosos, arcos, termas, coliseos, pincel, estatuas, bronces, escultura, y otra si hay más constante y más segura;

en todas cunde la infeliz polilla del voraz tiempo, autor de las verdades: no hay real corona, ni suprema silla, Sagrado Imperio, muros ni ciudades contra sus fuerzas. Todo lo aportilla, en todo imprime y causa novedades: los reinos muda, sus linderos trueca y hoy, donde ayer fue mar, ya es tierra seca.

¿Quién me dirá de la usurpada España el cetro oscuro de ásperos alanos?

¿Qué terrones rompió la inculta saña de almonides y antiguos turdetanos?

Como sintetizaba con precisión E. Orozco, «al finalizar el siglo xvi, en su general concentración o mirada hacia dentro que se produce en nuestra cultura, el humanista e historiador busca con interés el pasado propio y más que el general español, el local. Hay un afán por conocer y celebrar las antigüedades, glorias y grandezas de la propia ciudad. Por eso surgen al terminar el siglo y en los comienzos del XVII las historias locales en casi todas las ciudades españolas. Ese fondo de conocimiento y amor por el pasado local favorece la exaltación de sus monumentos» (1963: 29). Véase, entre otros, el poema de M. Martel (1967). 
Quién los épalos fueron, cuya maña

al Betis dio los muros sevillanos?

Los zacintos, los celtas, los ancones, ¿en cuál mundo tuvieron sus regiones?

Ya el tiempo los tragó en ruedas voltarias:

la romana y la griega monarquía

de Virgilio y de Homero plumas varias, murieron, y ellos viven todavía.

$\mathrm{Si}$ a sus versos los reinos dieron parias, también yo espero que a la musa mía rinda, a pesar del tiempo y de envidiosos, Roma sus muros, Rodas sus colosos.

$$
\text { (Libro II, 1624, f. 19r) })^{57}
$$

Solo por el hecho de haber recorrido en toda su amplitud la extensa obra no dramática de Lope de Vega hay que hacer notar la importante contribución de A. Sánchez Jiménez al volumen considerado como tejido conectivo de estas notas. Comienza como recordatorio con el conocido efecto que causó en el Fénix la tormenta que destrozó su huertecillo en la calle de Francos, originando en la emoción de su poema la evocación plural de las ruinas ${ }^{58}$ :

Otras Numancia de árboles y vides [...]

un Sagunto de flores y retamas [...]

Troyas de manutisas y claveles.

\footnotetext{
57 Para no alargar en demasía mi discurso referencio a continuación los principales pasajes consagrados al motivo: la magnificación de las ruinas locales de Sansueña (libro v, f. 77r), meditatio elegiaca sobre la laberíntica condición humana ante las ruinas de Cartago (libro XI, ff. 140r-v), visión dolorida en lejanía escópica de los restos y memorias de la España primitiva (libro XII, f. 154v), breve descripción de las ruinas latinas de Calabria (libro xVI, f. 192r); Venecia, ruinas pasadas y grandeza futura (libro xvi, ff. 193r-v). Véase al respecto la excelente edición de M. Zulaica López (I-II, Siero, 2017).

58 Compárese todo ello con el epígrafe que dediqué a «Lope y las ruinas de Sagunto: la ambientación pastoral en el romancero nuevo» (1999b: 268-274), limitado al soneto «Vivas memorias, máquinas difuntas»y los romances del pastor Belardo. También, en otra dirección E. Orozco Díaz ya había subrayado la «visión compleja» de ruinas y jardín en Lope que con «profunda e íntima emoción» prefigura lo que será caracterizador del romanticismo (1947: 127-128). Finalmente A. Carreño, partiendo de un verso de La hermosura de Angélica («Troya fui yo, que por mí mismo / como por Etna entraran al abismo») indica que «los sonetos de Lope en torno a las ruinas de Troya forman en sus Rimas todo un ciclo. Troya da en metonimia de la fama por el paradójico triunfo que esta adquiere a partir de su propia ruinas» (2001: especialmente 52-56, donde analiza «Fue Troya desdichada y fue famosa [...]» y «Árdese Troya y sube el humo oscuro $[\ldots] \gg)$.
} 
El motivo se explana en la escritura lopesca desde los romances de juventud a los poemas del ciclo de senectute, con «una insistencia arqueológica que convierte la obra del Fénix en una de las más ricas de este tópico». Nutrido corpus que Sánchez Jiménez examina notando su evolución, estableciendo taxonomías y resaltando los pocos conocidos textos de unos romances atribuidos (1601) y de La Circe (1624). Tras un repaso a la crítica de las ruinas lopescas establece, a un tiempo, el predominio de «su propia pasión mitologizada» y su voluntad de acoger la polivalencia del motivo. Las ruinas en la prosa de Lope recorren desde un pasaje del epistolario con el duque de Sessa, La Arcadia (1598), el raro uso en la dedicatoria de El peregrino en su patria, el contrafactum de La Arcadia (Pastores de Belén), donde incorpora un motivo pictórico desarrollado por los pintores flamencos a partir de 1440 (la representación del portal de Belén como un edificio ruinoso, motivo repetido en dos letrillas arromanzadas del libro), y la Dorotea, donde César usa la imagen de las ciudades en ruinas para advertir a Fernando que similar destino le afecta si aviva su amor por Dorotea. En la poesía narrativa de Lope se recogen seriadamente la presencia particular en El Isidro (1599), su desmesura en La hermosura de Angélica (1602) y más contenidamente en la Jerusalén, los Triunfos divinos y la Corona trágica. Troya ${ }^{59}$, pero también Sagunto, Numancia o Roma «son símbolos de la potencia irresistible y letal del amor» o expresión, sin más del paso del tiempo, con características relevadas en paisajes varios.

59 Tras Lope el recurso a las ruinas de Troya para una ponderación filográfica será objeto de innumerables variaciones. De entre ellas destacó un soneto de Antonio Balvás Barona que multiplica la implicación del amante para un juego de contrastes y parangones. Las ruinas son primero espejo y luego simple termino en una suma de reflejos que abre y cierra un distinto enamorado doliente, certificando en la voz que representa sin mediaciones al yo poético el verdadero ejemplo del eros destructor: A la contemplación de una ruina: «La máquina de Troya derribada / estaba Ardenio contemplando un día, / que cuando el tiempo vengador porfía / no hay Troya en pie ni torre levantada. / "Ay Babilonia — dice— en quien cifrada / se ve de amor la injusta tiranía, / tu desdicha compite con la mía, / iguales somos, no nos falta nada. / Marte y Fortuna han sido tus contrarios, / a mí el tiempo y amor en fuerzas iguales / que uno derriba lo que el otro apoya!" / Oíle y dije: " ¡Oh pensamientos vanos, / bien puede en la memoria de mis males / verse tu ejemplo harto mejor que en Troya!"» (1627: 142r). O este otro de P. Gonçálvez Andrada (f. 30v): Troya destruida: «A flébiles cenizas reducida / la cabeza del Asia respetada, / aunque fue por las armas desdichada / quedó por las desdichas conocida. / Por las llamas del odio consumida / Fénix fue por el fuego eternizada, / y la gloria al agravio vinculada / celebrada quedó por ofendida. / En láminas de eternos pedernales / sus desdichas los hados escribieron / con rúbricas de llamas inmortales. / Común alivio que a los males dieron /que fuesen conocidos por los males / los que por las venturas no lo fueron» (f. 30v).

Véase también los estudios, atendidos por A. Sánchez Jiménez (2019), de M. J. Gómez Sánchez Romate (1983), M. Á. Candelas Colodrón (2006) y F. Serralta, uno de los escasos excursos que atienden a las ruinas en el teatro (2017). 
En un apartado especialmente reflexivo: «La poesía lírica: ¿qué es poesía de ruinas?», Sánchez Jiménez (pp. 124-126) establece cuatro criterios interrelacionados entre sí:

1) «La temática central de la poesía de las ruinas es arquitectura derruida, no tumbas o cadáveres que serían más bien propias del motivo de la vanitas».

2) Trata de ruinas clásicas, de la Antigüedad (Roma, Troya, Itálica, Cartago, vestigia a los que solo secundariamente se les irán incorporando más tarde ruinas modernas (Calatrava la vieja, el castillo de San Cervantes, las torres de Joray).

3) Es lírica de descriptio, ecfrástica. Por tanto, su recurso central es la hipotiposis y la enargeia, «ya directamente por parte del sujeto lírico, ya por un personaje que se imagina contemplando las ruinas».

4) Esta contemplación llevará a una reflexión general sobre el paso del tiempo, que puede ser amorosa y particular, moral y general e incluso burlesca.

Aplicando estrictamente estos criterios el corpus de ruinas de Lope se reduce considerablemente. Cronológicamente hablando aparecen en primer lugar el romance «Mirando esta las cenizas», con un patetismo explícito en que Belardo afirma haber venido a este lugar «como a verdadero centro» y el romance «Dos ejemplos de fortuna» (1595) con la versión del cónsul Mario ante las ruinas de Cartago ${ }^{60}$; tras los romances de juventud, el soneto de las Rimas «Entre aquestas columnas abrasadas...», el célebre de El peregrino en su patria «Vivas memorias, máquinas difuntas...», y el burlesco del Tomé de Burgullos A imitación de aquel soneto «Superbi colli». Tras desechar «un romance atribuido», Sánchez Jiménez se centra en los dos sonetos de La Circe. El primero («Silvio, para qué miras esas ruinas...») es de «factura clásica, con

${ }^{60}$ El motivo aparece ya en Plutarco y está presente en Herrera. Aunque considera mi hipótesis de que se difundió a partir de la Historia romana de Velleius Paterculus (Lara Garrido, 1999a: 91110), prefiere la directa conexión clásica. Pero el trayecto puede ser otro, porque con idéntico matiz consolatorio y glosando a Paterculus el encuadre fue recogido por un epigrama de Fausto Sabeo, De C. Mario et Cartagine (1556) y desde él lo desarrollaría Tasso en su soneto "Sacra ruina ch'l gran cerchio giri...», que incidiría en las múltiples imitaciones españolas según el modelo del Suberbi colli. Sobre las ruinas de Cartago, negando la existencia de resto alguno, (ni siquiera el polvo) es la fantasmagórica visión de un soneto relativamente tardío de Francisco de la Torre (1654: 59), A las ruinas de Cartago: «Aquella gran ciudad que fue, que ha sido / nido a la fama, patria a tantas glorias, / despojos ya del tiempo en sus vitorias / ganado por la parte de perdido. / Fénix es, de su polvo renacido / a vacilante vida de memorias, / luz aun no defendida en las historias / del aire turbulento del olvido. / Nada es al fin la que se vio altanera, / tan émula al olimpo cuan vecina, / no la deja aun ser polvo aquel estrago, / porque si fuese polvo aun algo fuera. / ¿Pues que será lo que se ve? Ruina. / Lo que no se parece, esto es Cartago». 
los elementos habituales: el personaje contemplativo, el deíctico, el templo presumiblemente grecorromano, las columnas rotas y el tono elegiaco, aquí regado por las lágrimas del espectador; por este lado contienen la ruina metafórica de una belleza humana: la desaparecida lozanía de Filis». El otro soneto, A un cadahalso, muestra tras su análisis que pertenecía más bien «al subgénero de la poesía de la privanza».

Las conclusiones del ensayo son totalmente asumibles: «El sutil camino con el que Garcilaso abrió la poesía de las ruinas del Siglo de Oro no fue el más transitado, sino que resulta más bien excepcional. Se diría que el soneto XxxIII llamó la atención sobre el tema de las ruinas y sobre el modelo textual evocado, el Superbi colli y, en menor medida, Tasso, y que nuestros escritores se mantuvieron en él probablemente impulsados por la inclusión de Superbi colli en las Anotaciones de Herrera. Posiblemente el peso de los poetas andaluces (Herrera, Caro, Cetina) y de los grandes poemas sobre Itálica fue determinante para esta deriva» (p. 137) ${ }^{61}$.

${ }^{61}$ El término de la deriva se encuentra en las ruinas modernas e innominadas. Así en el soneto anónimo A las ruinas de una iglesia: «¡Ay de mí!, cómo un templo tan sagrado / como este, tan capaz y enriquecido / se mira entre cristianos tan perdido / que solo es bueno ya para ganado. / Cualquier pastor le habita sin cuidado / de ver que aquestos mármoles han sido /trono, sitial, altar, estancia y nido / del cordero de Dios sacramentado. / Viose postrado en tierra de repente / y para confusión de nuestro celo / grosero por la huella irreverente. / El estar otras veces era un cielo / dentro de estas paredes, / y al presente / en ellas todo es campo y todo es suelo» (Ms. 17492 de la B. N. de España, f. 235v). Como anónimos se copian estos dos sonetos en el mismo manuscrito que transmite la serie de los dedicados a Itálica (cfr. nota 68). Ambos figuran como anónimos y se dedican a ruinas de escasa entidad: Descripción de la villa de Teba y su castillo: «Rajadas peñas, cerros empedrados, / tan altos que compiten con los cielos, / de cernícalos, cuervos y mochuelos / albergues, si durables apropiados. / Caducos edificios que postrados / de la oprimida Troya son consuelos, / sin que sus baluartes tengan celos / de unas rotas, o menos acabados. / Cuatro casas de palma, una zamorra, / poca gente de luz, mucho pardillo, / cuestas inaccesibles, viento eterno, / esparto de lo fino, una mazmorra, / aljibes mil con agua en el invierno: / aquesta es Teba y este su castillo» (f. 57r); Al castillo de Guadaira, casi arruinado: «Edificio decrépito y caduco / que forzado del Céfiro barajas / esas murallas con que en vano atajas / baluartes que dieron al trabuco. / Si un tiempo trono fuiste a algún Maluco / ahora en ti se están haciendo rajas / golondrinas, cernícalos y grajas, / mucha cigarra y mucho abejarruco. / Tu mazmorra, tu cima, noria o pozo / habita el gorrión, tordo o paloma: / arca eres de Noé, tremendo establo. / Tu ruina amenaza y tu destrozo, / pues te apolilla el tiempo y da carcoma, / ¡acábate de hundir ya con el diablo» (f. 59v). Del cartapacio de Pedro Hernández de Padilla destacó y dio a luz R. Menéndez Pidal (1914: 302) otro díptico de sonetos que, como en una peregrinatio amoris conducen el itinerario a una reduplicada meditación de conceptos contrastados. Sirve de referente material, propiciador en cada caso del discurso filográfico, el estado de cada ruina. Pasando por Calatrava la Vieja: «Ya llego donde fueron las banderas / de las rojas señales levantadas, / dejando vidas y honras asoladas / aquí del pueblo de Israel postreras, / donde dejó las arrogancias fieras, / aquel Gran Padre por el suelo echadas, / que lo fue de familias que hoy cruzadas / en la heredad de Dios son las primeras. / Aquí hay un río, imagen de mis ojos, / esperanzas y torres por el suelo / cuales las fabriqué en mi pecho altivo. / Dio Calatrava al tiempo sus despojos, / más tengo yo por tan contrario al cielo, / que 
Conectarían estas consideraciones finales con lo que ya manifestara al analizar «la poética de las ruinas en el Barroco»: «A cada movimiento innovador - escribía - corresponde la disposición diferenciada hacia la realidad y el recurso a medios expresivos que conforme avanzamos en el XVI se van complicando con la adherencia de los modelos previos cada vez más inducidos a convertirse en una cadena temática. La lírica barroca partirá, pues, en sus descubrimientos de un topos extenso y sus resultados conectan con refracciones más o menos intensas de la tradición renacentista, aunque su significado y aun el objeto a que se aplica sea ya de diferente trascendencia. En una general asociación a lo inmediato se produce, primero, una nacionalización del paradigma, y luego un descenso en la dignidad temática paralelo a la polivalencia de significado y a la diversificación retórica, que terminará no solo recogiendo ruinas de un mero valor localista, sino hasta rompiendo ese precepto implícito en el talante dignificador del Renacimiento de que "les décombres épars d'une ville ancienne n'accedent pas à la dignitè des ruines et ne suscitent aucun interêt artistique"» (R. Mortier, apud Lara Garrido, 1981:386).

Es que, como mostró en páginas modélicas G. Sobejano, resulta necesario un incremento de los estudios en que, al igual que en su caso ejemplar se establezca «¿cómo desprender los valores de las imágenes concretas conscientemente elegidas por el autor para animar aquellos valores?» Porque «importan los valores pero éstos sólo cobran vida en lo concreto». Y así en el soneto quevediano A Roma sepultada en sus ruinas, «borrados el nombre y las señas históricas de Roma, los nombres de sus colinas, la realidad antes gloriosa y ahora decrépita de sus muros y murallas; olvidada la selección hecha por el poeta de uno o dos modelos humanistas en su tiempo en el que los pueblos románicos, orgullosos de su latinidad y de su madurez, volvían a Roma la mirada para aprender de su destino, apenas quedaría en este soneto la onda abstracta del tiempo que pasa o el agua material de todo rio que corre, pero desaparecería la viva corriente de la tradición, el flujo de la cultura». A su vez, importa la ascendencia, que, reduciéndola en el soneto quevediano al soneto de J. Du Bellay «Nouveau venu, qui chesches Rome en Rome...» y el epigrama latino de Ianus Vitalis De Roma, explicitan una dialéctica de

muerto el gusto me conserva vivo»; Estando en Salvatierra: «Estas reliquias de tu antiguo asiento / segunda vez he visto, joh Salvatierra!, / y hallo en ti y en mí que el tiempo atierra / tus presunciones como mi contento. / Vivo está de los dos el fundamento / para memoria de una ilustre guerra: / a mí hecho en el cielo, a ti en la tierra, / que competía con el firmamento. / Podré envidiar de hoy más tu mala suerte, / porque me hallo en Lisis tan malquisto / que tu caída abonará mi muerte. / Resiste el mal mejor que yo resisto, / que cual te viste acaso podrás verte / y yo no podré verme cual me he visto». 
posibilidades, en las que, por ejemplo, «a diferencia del vocativo mantenido en el epigrama y del anulado, o asumido por el hablante en el soneto francés, la invocación quevediana inicial ("oh peregrino!") truecase en ese final " $\mathrm{OOh}$ Roma!" que atestigua el acercamiento personal — sin intermediarios, ya olvidado- al objeto mismo de la elegía ("Oh Roma, en tu grandeza, en tu hermosura") quedando así la ciudad aclamada tres veces (en su nombre, en su magnitud, en su belleza) y preparado el lector a recibir la sentencia, no en un presente abstracto y genérico, sino en el contraste entre lo que efectivamente ocurrió ("huyó lo que era firme") y lo que efectivamente pasa y no pasa ("solamente / lo fugitivo permanece y dura") [...]. El cotejo del poema latino con el francés y con el español denuncia con claridad, frente al signo epigramático de los dos primeros (agudeza, ejemplaridad, amonestación), la índole elegiaca del último: detenida contemplación del bien perdido y honda participación en el desconsuelo que la revelación alumbra; por eso el río, aquí, no pasa rápido, hacia el mar, o huye hacia él, sino que llora a la ciudad sepultada en sus ruinas» (Sobejano, 1987: 110-111 y 115-117).

Por eso, a fuer de parecer repetido, considero esencial volver esa dialéctica entre esencia y ascendencia al núcleo originario en su esencia y ascendencia del que acaso sea el conjunto más nutrido y rico del motivo de las ruinas en el Siglo de Oro: el de los poetas sevillanos y las ruinas de Itálica y ad lateres, partiendo de la variabilidad que el peso de la res histórica y el compromiso presente o ausente con la fugacidad ascética y la hipérbole petrarquista de la ingratitud amatoria introducen. Y concluyendo en la apertura misma de esa esencia conformando ascendencias varias, donde la atracción por unas ruinas cercanas hacia las que mueve una sentimentalidad no meramente arqueológica (anhelante, más bien, de una fusión anímica) que contempla los signa de un idéntico destino a lo humano para elevarse a consideraciones filosóficas individualizadas en su constante venir referidas a la nostalgia y a la melancolía.

El texto nuclear, como punto de partida y reflexión, se encuentra en la extensa nota que a propósito del soneto Xxxv de Garcilaso («Boscán, las armas y el furor de Marte [...]») dedica Fernando de Herrera a Cartago ${ }^{62}$ : «Esta ciudad, según Polibio en el lib. I, está sobre un monte o cabo, que se tiende al mar

62 El texto del soneto de Cetina lo recojo de la magna edición de J. Ponce Cárdenas, quien asume la sugerencia de N. Alonso Cortés sobre que «la adaptación del modelo de Castiglione a las ruinas cartaginesas podrían relacionarse con la posible participación de Cetina en la fracasada campaña imperial de Túnez en 1541». Recoge y anota el texto explicativo preliminar de Fernando de Herrera, comentando cómo este «defiende que Gutierre de Cetina se tomará la licencia poética de evocar unos restos majestuosos que no solo no pudo ver durante su participación en la empresa de Túnez, sino que ni siquiera figuran en las fuentes documentales de la época antigua». J. Ponce (2014: 461-463) realiza un refinado análisis del soneto, comparándolo con el de B. Castiglione. 
y tiene forma de isla, sino que se junta con África por un ismo estrechísimo. La misma ciudad en parte se estrecha y cierra con el mar, y en parte con las lagunas y estaños. La latitud de la tierra, que la junta con África, no contiene más que tres mil pasos. De la una parte se extiende al mar, en la otra está Túnez en el seno de la laguna. Hoy se ven algunas antiguas reliquias de su grandeza, y está vivo el cabo o promontorio de Cartago, pero no aquel ismo y tierra tan estrecha, porque se ha hecho más ancha con las casas que se han derribado. Cerca del ismo se ve un río, dicho Maquera. Fue Cartago en la garganta de aquella laguna por donde se va a Túnez; pero más adentro hubo una isla pequeña, o montecillo muy llano en medio de las aguas, en el cual los moros y después los turcos levantaron un castillo, que por estar en la garganta de aquella laguna lo llamaron Goleta. En el seno de esta laguna está Túnez, apartada de Cartago por la laguna 18 millas. La imitación de este soneto parece que es de aquel tan celebrado que compuso el conde Baltasar Castellón, y tradujo en español Cetina con grande espíritu. El toscano dice así:

Superbi colli, et voi sacre ruine che'l nome sol che Roma anchor tenette; ahi che reliquie miserande havete, de tante anime eccelte e pellegrine.

Teatri, archi, colossi, opre divine, trionfal pompe, gloriose e liete, in poco cener pur converse sete e fate al volgo vil favola al fine.

Così se ben un tempo al tempo guerra fanno l'opre famose; a passo lento e l'opre, e i nomi insieme il tempo atterra.

Vivrò dunque fra miei martir contento, che se'l tempo da fine a cio ch'è in terra, dara forse anchor fine al mio tormento.

Cetina pasó todo este apartado y ornamento de edificios y fábricas romanas a Cartago; donde él por ventura no vio rastro de algunas dellas, ni los debió leer en escritos antiguos, pero cuando esto se condena será error de accidente, y por eso liviano. Basta que lo trasladó ilustremente y que es uno de los buenos sonetos que tiene la lengua española:

Ecelso monte, do el Romano estrago eterna mostrará vuestra memoria; soberbios edificios do la gloria aún resplandece de la gran Cartago.

Desierta playa, que apacible lago lleno fuiste de triunfos y vitoria, 
despedazados mármoles, historia

en quien se ve cuál es del mundo el pago;

arcos, anfiteatros, baños, templo,

que fuisteis edificios celebrados,

y ahora apenas vemos las señales;

gran remedio a mi mal es vuestro ejemplo:

que si del tiempo fuisteis derribados,

el tiempo derribar podrá mis males ${ }^{63}$.

\begin{abstract}
El soneto de Cetina iba a dejar una profunda huella, como incio de una serie que va alcanzar su ápex justamente en la referencia a las cercanas ruinas de Itálica. Herrera, autor de un significativo haz de sonetos sobre ruinas ${ }^{64}$,
\end{abstract}

${ }^{63}$ Cito el texto de las Anotaciones por A. Gallego Morell (1972: 215-216). Como observó atinadamente G. Cabello (1981: 322-323), «Herrera se nos presenta distanciado ya de las reflexiones e imágenes que despiertan las ruinas en la literatura clásica latina y en la del primer Renacimiento, incluyendo aquí desde un Petrarca ante el Coliseo romano hasta el Nebrija que canta a Emérita y a Itálica. Ya no nos enfrentamos a la observación directa de unas ruinas que conducen a la contemplación histórica, al entusiasmo arqueológico, a un ferviente sentimiento patriótico o a una emoción elegiaco-sentimental, que las recrea en su pasado esplendor, bajo un recuerdo idealizante [...]. El paradigma clásico del motivo de las ruinas, sustentado en la versión cetiniana, es absorbido y asimilado por Herrera en una forma particular, iniciando un proceso de apertura significacional [...]. A través de la descripción topográfica que realiza de Cartago, va explicitando la contraposición entre las gloriosas construcciones de una civilización en auge y el estado de destrucción al que las arrastra el peso del tiempo. Partiendo de este principio base, las diferentes realizaciones poemáticas del tema extraían consecuencias de tipo ético y amatorio. Pero Herrera no se autolimitará a la dirección que marcan los sonetos que él mismo recogió. Su profunda erudición y su conocimiento de las literaturas clásicas e italiana no pueden dejar de impulsarle a fuentes de otra procedencia. La íntima necesidad de creer en la inmortalidad de su obra poética le llevará a tematizar el motivo de las vanitas en un sentido opuesto al que irá tomando cuerpo en la poesía barroca. En sus poemas encontraremos una contaminatio entre la res histórica y el motivo retorico. Introduce nuevas ruinas, recupera otras ya tematizadas en composiciones clásicas e incluso anuncia las ruinas acuáticas que más tarde desarrollaría Rioja. Realiza una breve cala en un tema fundamental en el barroco, el jardín en ruinas. De ahí que insista en la apertura significacional que efectúa Herrera sobre un motivo poético que ya poseía fuertes rasgos potenciados de lexicalización desde su introducción en España» (véase complementariamente cuanto he recogido en la nota que antecede). Sobre las ruinas de Salmedina y su visión, sintetiza C. A. de la Barrera que «existen abiertas por el mar, a tres leguas próximamente de Sanlúcar de Barrameda, enfrente, y a tres cuartos de legua de la parte de Chipiona constituyendo un grupo de escollos y se divisan perfectamente en los días claros [...]. Son muy escasas las noticias que dan de Ebura los antiguos geógrafos; de la catástrofe que la sumergió no se conserva ninguna» (Rioja, 1867: 15-16 y 290-291).

${ }^{64} \mathrm{G}$. Cabello concluye sus intensas y novedosas notas de lectura de la poesía de Herrera (donde desestima la «superposición descontextualizada» de un O. Macrí que se refería tanto al «atávico motivo senequista [...] de la vanitas vanitatum» como a una «construcción espiritual» barroca desarrollada y «diversas formas y tonos dentro de aquella especie de prerromanticismo hispalense») afirmando que el paradigma clásico «es seguido por Herrera a partir de una óptica distanciadora y tendente a diluirlo». Cuando lo recoge conduce el tema hacia una apertura 
compuso el que de formas más directa conformará el molde de la serie originada por las sevillanas:

Esta rota y cansada mansedumbre, osada muestra de soberbios pechos; estos quebrados arcos y deshechos y abierto cerco de espantosa cumbre,

descubren a la ruda muchedumbre su error ciego y sus términos estrechos; y solo yo en mis grandes males hechos, nunca sé abrir los ojos a la lumbre.

Pienso que mi esperanza ha fabricado edificio más firme, y aunque veo que se derrumba, sigo al fin mi engaño.

¿De qué sirve el juicio a un obstinado que la razón oprime en el deseo? De ver su error y padecer más daño.

La descripción herreriana presenta una serie de sintagmas característicos que volverán a aparecer una y otra vez en los sonetos que recrean en Sevilla el motivo de las ruinas de Itálica (la «rota y cansada pesadumbre», los

significacional de diferentes variantes. La más importante es la ampliación del motivo «al ser contrastado con la idea de la poesía como portadora de eternidad». Si las obras arquitectónicas y plásticas estas destinadas a la desaparición, las poéticas «son instrumento de inmortalización y resistencia frente al tiempo. Al convertirse esta rebelión contra la muerte en consecuente del tópico de las ruinas, estas dejan de funcionar como modélica simbolización de la aniquilación de las obras humanas en un plano esencial y se encargan de realzar la idea horaciana del non omnis moriar» Distingue tres «núcleos generadores» de esta nueva tematización que opone el paradigma clásico a la idea de «la poesía inmortalizadora: 1) Ruinas vencidas por el tiempo / Talía inmortal e inmortalizadora de los héroes cantados por el propio poeta; 2) Artes plásticas sumergidas en el olvido. / Poesía viva a través de la historia; 3) Ruinas como material del trabajo poético inmortalizador. / Amor como material poético indigno de sobrevivir al poeta». Por otra parte, el «acudir a nuevas ruinas no existentes en un paradigma que se limitaba normalmente a Troya, Roma y Cartago, configuran un nuevo factor de la diferenciación herreriana. Para interpretar este hecho hay que tener muy en cuenta su posicion respecto a lo que denominamos nacionalización del tema: Herrera va a inspirarse en ruinas que manifiestan un pasado de trascendencia histórico-patriótica y que son capaces de despertar sentimientos nacionales comunes entre los lectores. En sus poemas se cantará a las ruinas de Sagunto, probablemente las de Itálica y, en un sentido muy especial, las de Tartessos». En el soneto supuestamente dedicado a Itálica, según la hipótesis de Coster, se nota claramente cómo el desengaño queda unido al motivo de las ruinas y Herrera da expresión poética a su angustia personal, a su mayor obsesión: la pervivencia de su obra. Como introducción a una serie de tercetos que abordan un proceso histórico a través de diferentes ruinas, el escritor nos dice: «Veo el tiempo veloz que se adelanta / y derriba con vuelo presuroso / cuanto el hombre fabrica y cuanto planta. / ¡Oh cierto desengaño vergonzoso! / ¡Oh grave confusión de nuestro yerro: / claro enemigo, amigo sospechoso!» (1981: 318-321). 
«quebrados arcos y deshechos», o la visión del anfiteatro como «abierto cerco de espantosa cumbre») «y desde luego la fórmula deíctica inicial, con la expresión de una inmediatez que animiza, por su verismo, la contemplación angustiada. Esta fórmula (complicada por la interposición entre el demostrativo y el sustantivo de un determinativo) se convertirá en la carta de identidad de las recreaciones de los sevillanos» (López Bueno, 1986: 66; también Ferri Coll, 1995: 60-67). A propósito de los poemas a Itálica se ha llegado a pensar que se trata de un tema de academia (D. Alonso) ${ }^{65}$. Merece un punto de reflexión y algo de perplejidad la forma con que una documentación inequívoca vino a dar cuerpo a la intuición fantaseada a propósito de Medrano. Tras explayarse en la exacta ubicación del pago del poeta, escribía en 1948: «Allí, en Mirarbueno, todo lo que ennoblece la vida lo tenía al alcance la mano: paisaje para explayar el alma, la emoción de lo más venerables ruinas en la inmediata cercanía, y con ella, tanta ocasión de discusiones amistosas (nos imaginamos) [...]. Para pensar así, aflojamos la rienda a la imaginación, pero solo un poquito. En verso de Medrano ha quedado constancia de una invitación suya para que se acoja al reposo de Mirarbueno. ¿Qué duda cabe de que los mejores poetas sevillanos serían alguna vez sus huéspedes? Sí, allí estaban las ruinas, al lado, para mover aficiones arqueológicas y dar curso a pensamientos estoicos» (Alonso, 1974: 147-148).

Poco tiempo después, A. Rodriguez Moñino daba a conocer la Epistola de Fernando de Soria a Lucas de Soria, canónigo de la Santa Iglesia de Sevilla66,

${ }^{65}$ Por otra parte, la meditación de un grupo de poetas ante otras ruinas, evocada años después, no tiene nada de singular. Cristóbal de Mesa rememora en su epístola a Tomás Hernández de Medrano el encuentro con Baltasar de Escobar y Cristóbal de Virués en que este tras leer sus propios versos, «admirado del sacro gran palacio / dijo de las romanas antiguallas / lo que dice Virgilio y dice Horacio. / Trató de las victorias y batallas / y de la Roma antigua y la moderna, / arcos, puertas, columnas y murallas». Inevitablemente el discurso de Mesa pasa a dar cuenta del transcurso del tiempo: «Si os halláis como yo, cascado y cano, / y tan solo nos queda la memoria / de aquel buen tiempo juvenil lozano, / pensemos que se pasa así la gloria / de aqueste mundo, y que él nos desengaña, / que toda cosa suya es transitoria» (Caravaggi, 1978: 194-195).

${ }^{66}$ Refiriéndome a «la atracción por unas ruinas cercanas hacia las que mueve una sentimentalidad no meramente arqueológica» yo escribía ya que «en el caso donde encontramos, junto a la Canción de Rodrigo Caro, una mayor mediatización de la estructura de sentido por el paradigma retórico, como es en el soneto de F. de Medrano, la realidad de una directa y meditativa visión de esas ruinas cercanas está documentada». Cuando Hernando de Soria Galvarro insistía en su Epístola a Lucas de Soria a abandonar la vida de palacio «donde es el primer dogma el artificio» piensa en ese retiro «en soledad» al «campo dulcemente triste»: «Do ve el nudo silencio la ruina [...] / y que a filosofar nos persuadía» [remitía entonces al artículo de A. Rodríguez Moñino (1976: 137162)]. Qué mejor comentario, al mismo tiempo, a la interconexión entre Medrano y la Canción a las ruinas de Itálica que vitaliza el nuevo arranque coloquial y efusivo con que Caro, dirigiéndose a ese imaginario acompañante, Fabio, quiebra la tonalidad arqueológica de las dos primeras redacciones y centra su visión en el gradual pero directo imaginar de una gloria pasada en la ruina presente» (Lara Garrido, 1981: 392-393). 
donde las consideraciones sobre el valor y el paso del tiempo se concreta primero en referencias personales sobre la fugacidad para alcanzar «la ponderación de un sentido largamente anunciado. Retiro de un provechoso otium intelectual que, como tantos textos de la época [...] testimonian una herencia directa de la exquisita recessio horaciana». Para un retiro tan delicioso, pondera el monasterio de San Isidoro del Campo ${ }^{67}$ «a tres millas de Sevilla desde el que se divisa Itálica y donde recuerda cómo muchas veces se sentaban a descansar y a filosofar a vista de las ruinas su amigo Francisco de Medrano y él al regresar paseando de la finca de aquel [...] Soria construye así un puñado maravilloso de versos, cifra de incitaciones varias entrecruzadas en el natural descanso de una epístola moral, con su definida tradición retórica, por una parte, pero construida también sobre vivencias reales de exquisita añoranza (y hasta de melancolías por quien es ahora habitante de palacio), recordando sus años pasados en el Aljarafe sevillano cerca de su caro y dulce amigo Medrano» (López Bueno, 2001: 274-277):

Tan adelante en esto he caminado cual suele nuestro vago pensamiento que el sitio halla y lugar determinado.

Será, pues, si te place aquel convento que tres millas la gran ciudad vecina tiene y sobre un collado hermoso asiento, do ve el mudo silencio la ruina de Itálica deshecha que conserva restos de la alta majestad latina,

y el grande anfiteatro a quien reserva forma el tiempo y asiento levantados mas cubiertos de malva y de vil hierba.

Acuérdome de estar allí asentados muchas veces Medrano y yo viniendo de su hacienda, cerca, aunque cansados, y alguna solitaria cabra viendo pacer aquel teatro que algún día tanta gente vio en sí y festivo estruendo,

${ }^{67}$ Un importante panorama sobre la historia de la arqueología en Itálica es debido a P. León (1994: 29-37). Antes de detenerse en la figura de Rodrigo Caro indica expresivamente que fue Ambrosio de Morales en su recorrido indagador por las antigüedades de España el que, basándose en fuentes clásicas, llegó a identificar Itálica «con el lugar que le era propio; esto es con las ruinas próximas al monasterio de San Isidro, sobre la margen derecha del Guadalquivir y a poca distancia de Sevilla. «Las premisas establecidas por Morales fueron punto de partida para la historiografía posterior, en ámbitos tan diversos como los que puedan representar Justo Lipsio, cuando se refiere al anfiteatro de Itálica o bien Morgado (Historia de Sevilla, 1578) y Caro» (p. 31). 
de aquella muda soledad salía concento y voz que nos hablaba clara y que a filosofar nos persuadía.

Este sitio por ti agora buscara, y en memoria del caro y dulce amigo el campo dulcemente triste amara.

Vieniérasme tú a ver y yo contigo de mí ¡o cuán larga historia refiriera!, y lo mismo hicieras tú conmigo;

repasárase desde la primera niñez nuestra las cosas que han pasado sin reservar las de la edad postrera.

Después tal vez a estudio agreste dado, a la vejez la agricultura cara remitiera la cuerda a mi cuidado $[. .$.

Es así como «una corona de nombres áureos sevillanos se aglutina en torno al motivo de las ruinas de Itálica» ${ }^{68}$. El célebre soneto II, 7 de Medrano ha sido

${ }^{68}$ Se reúnen la mayoría en el Ms. 20355 de la B. N. de España: Sonetos varios Recogidos aqui de diferentes Autores casi de manuscritos como de algunos impresos por Don Joseph Maldonado Dávila Saavedra. Vezino de Sevilla año de 1646, ya conocido por C. A. de la Barrera o F. Rodríguez Marín. Así el de Don Juan de Espinosa: «Itálica infelice que del hado / inútil sierva yaces en olvido / a cuya grave injuria consumido / conserva aun tu ruina el tiempo airado. / Pues que permite Júpiter sagrado / fue el soberbio teatro sustenido / hoy ilustre cual la antigua edad lo vido / en los insignes arcos levantado. / ¿Por qué en la ciega confusión envuelve / sus templos y arcos? Solo permanece / la que en humana sangre fue bañada. / Cuando tu gloria en polvo se resuelve / porque la infama arena no perece / tanto de crüeldad y horror la espanta». Y el de Francisco de Villalón: «Soberbia y más gloriosa pesadumbre / un tiempo, ya caduco polvo vano / a quien (¡oh grave afán!) el soberano / hado cambió en tiniebla tanta lumbre. / Itálica infelice, ¿do la cumbre? / ¿do está la majestad? / El inhumano anfiteatro, ¿dónde? / Oh fiera mano del tiempo, / tanto puede tu costumbre. / Yo me vi en las estrellas levantado, / yo sé tocar su luz serena y pura. / Caí cual tú: gran bien ambos perdimos. / Lloraré de los dos la muerte clara / y lloraré que el tiempo aun no ha dejado / esperanza de ser lo que ya fuimos». Y el de don Fernando de Guzmán: «Vide la grande Itálica famosa, / el miserable sitio y las señales, / y de tan grandes fábricas y tales / solo una muestra, sombra dolorida. / Y en soledad desierta y lastimosa / las cosas de los dioses inmortales / hechas ciegas cavernas de animales / que la edad luego iguala toda cosa. / Más ni pudo hacer el impío hado/ que algún roto arco, anfiteatro o templo/ no quedan por testigos de su gloria. / Así de aquel mi grande amor pasado / que destruistes vos ahora contemplo / mil ruïnas que aun restan por memorias». A las ruinas de Itálica o Sevilla la Vieja: «Oh Itálica breve, ya tu lozanía/ rendida yace al golpe de los años! / ¿Quién con la luz que dan tus desengaños/ en la sombra veloz del tiempo fía? / Cedió tu pompa a la fatal porfía/ de tirana ambición de los extraños; / mas hízote el ejemplo de tus daños / libre de sabios, de ignorantes guía. / Mal dije, no humilló tus torres claras / tiempo ni emulación con manos fieras, / que a resistirte de los dos triunfaras. / Moriste, sí, de ver que si hoy vivieras / ni a tus hijos más lauros les hallaras/ ni del mundo en el ámbito cupieras» (Poesías divinas y humanas del P. Pedro Quirós, religiosos de los clérigos menores de esta ciudad de Sevilla, Sevilla, 1887, pp. 2-3). A ellos hay que añadir la más tardía imitación del soneto de Medrano 
considerado unánimemente por la crítica como el elemento vivificador de la poesía de las ruinas en aquel entorno bético. Al igual que el modelo remoto de Castiglione, de la pieza de Medrano dimana una clara positividad filográfica, que ya había sido subrayada en tierras toscanas por otra célebre composición; «el muy difundido soneto de Ludovico Paterno, en su aplicación erótica positiva («se colonne, trofei, tempi, archi e fori»). Y el esquema enumerativo múltiple sería seguido de cerca por un amigo de Medrano, Cristóbal de Mesa, en otra pieza breve dedicada a los despojos de Roma». Y es así como surge el modelo con el que Francisco de Medrano, en un texto que se supuso compuesto para una academia literaria, instaura «la fórmula de apertura del demostrativo inicial, combinado con el hipérbaton por trasposición $»^{69}$ de un magistral soneto, que inexcusablemente debe figurar en cualquier estudio sobre el motivo de las ruinas:

Estos de pan llevar campos ahora fueron ya un tiempo Itálica. Este llano fue templo. Aquí a Teodosio, allí a Trajano puso estatuas su patria vencedora.

En este cerco fueron Lamia y Flora llama y admiración del vulgo vano, en este cerco el luchador ufano del aplauso esperó la voz sonora.

¡Cómo feneció todo, ay! Mas erguidos, a pesar de fortuna y tiempo, vemos estas y aquellas piedras combatidas.

Pues si vencen la edad y los extremos del mal piedras calladas y sufridas, suframos, Amarilis y callemos ${ }^{70}$.

acogido en las Obras en verso de Esquilache: «Destos campos que visten rubias mieses / Itálica es aquel, este sus muros, / que entre el arado vil no están seguros / de la violenta mano de los meses. / La que de aceros, flechas y paveses / ceñidos vio sus homenajes duros, / aun hoy del Betis los cristales puros / ni la respetan mansos ni corteses. / Deshecha yace en dudas y opiniones, / si fue otro tiempo Itálica gloriosa / que honraron tantos triunfos y blasones. / ¡Oh fuerza de los años poderosa! / pues muros y arcos en olvido pones / ¿qué harás de Silvia solamente hermosa?» [con el título A Sevilla la Vieja figura en la antología de J. M. Blecua (1982: II, 160)].

69 J. Ponce Cárdenas, «Entre Sevilla y Salamanca: Un poeta en la historia literaria», en el «Prólogo» a Medrano (2005: cXXXV-CXXXVI).

${ }^{70}$ Medrano (2005: 95-96), con su extensa y ejemplar anotación, con la que encuadra el soneto en «la poesía silente de las ruinas (donde se detallan los rincones más característicos del espacio urbano: templo, plaza ornada con estatuas, anfiteatro), sirve de correlato objetivo a la situación del yo lírico, que extrae de las rocas la lección del preceptivo silentium amoris y un atisbo de esperanza para un amoroso mal». 
Junto a él, una serie de sonetos que apuraban «en un margen estrecho de posibilidades buscando eficacia estética que coadyuvara con la expresión del exemplum de la fugacidad del tiempo, con su consiguiente estela del desengaño y de la vanitas». Es la aplicación que, por su frecuencia, se trivializa en las mediocres realizaciones de un Fernando de Guzmán ( «Vi de la grande Itálica famosa...») o de un Juan de Espinosa («Itálica infelice que del hado...») para venir a encauzarse por el interrogante Ubi sunt — nunca más gratuito el engranaje de dos tópicos- en Pedro de Quirós («Itálica, do estás? Tu lozanía...») o Francisco de Villalón («Itálica infelice ¿do la cumbre? / ¿Do está la majestad? ¿el inhumano anfiteatro / dónde?».

\section{A las ruinas del anfiteatro de Itálica}

Estas ya de la edad canas rüinas, que aparecen en puntas desiguales, fueron anfiteatro y son señales apenas de sus fábricas divinas.

¡Oh, a cuán mísero fin, tiempo, destinas obras que nos parecen inmortales! ¿Y temo? ¿Y no presumo que mis males así a igual fenecer los encaminas?

Este barro que llama endureciera y blanco polvo enmudecido atara, ¡cuánto admiró y pisó número humano!

Y ya el fasto y la pompa lisonjera de pesadumbre tan ilustre y rara cubre hierba y silencio y horror vano ${ }^{71}$.

\footnotetext{
${ }^{71}$ Rioja (2005: 99-101), con extensa anotación sobre el motivo de las ruinas. A Rioja se debe la ideación en el molde del soneto de las ruinas fantasmagóricas que se divisan en el fondo marino: la Salmedina, que corresponde especularmente al mito de la Atlántida hundida, aunque su localización exacta y la equivalencia de su nombre como «gran ciudad» ya los había referenciado hacia 1760 P. Patricio Gutiérrez Bravo. A ello se refieren los sonetos «Este ambicioso mar que en leño alado» (p. 48). «Este mar que de Atlante se apellida» (p. 67) y «¿No viste siempre en firme lazo atadas? [...]» (p. 95). Rioja canta la «admirable alta ruina» de la que hasta se desconoce el nombre cierto y que siendo «en otra edad divina / ha entre soberbias ondas sepultado». Al igual que «ya borrara / el ancho imperio y el poder de Atlante», el continente al que remite el segundo de los sonetos: «La parte más lucida / del orbe, y yace envuelta en alto olvido: / vivir el nombre apenas ha podido / y fue mayor que la África encendida». Pero si Rioja incrusta en el módulo formal más común el motivo de «las ciudades enterradas bajo el mar», en Herrera la apertura significacional de este se anuncia ya el tema. «En su poetización destacan ciertas peculiaridades: las ruinas no son marinas sino fluviales y Herrera pedirá al Guadalquivir que permita la reaparición de Tartessos, tras haber levantado el curso de sus aguas ("Alza del hondo seno / con ramosos corales enlazada / la venerable frente, / y en el curso sereno / ilustra tu ribera celebrada / sagrado río Hesperio; / a quien las claras aguas de Occidente / se reconocen imperio / y con ledo semblante / Tartessos del olvido se levante". Tras este verso, Herrera pasa
} 
Y la serie de sonetos sobre ruinas más majestuosamente equilibrada la proporcionará Juan de Arguijo: el I de sus sonetos («De la fenisa reina importunado...») remite «al arquetipo del entrelazamiento de amor y desolación que figura en el célebre soneto modelo de Castiglione sobre las ruinas de Roma [...]. Con la Cartago del soneto I se relaciona estrechamente el II («No los mármoles rotos que contemplo...») cuyos mármoles rotos (los de la ciudad de Dido pero también los de Sagunto) son restos en que se espejea el amor del yo poético. Y si en Cartago se centra el soneto III, cuyo soberbio monte remite al modelo de Castiglione («Este soberbio monte y levantada...») en las de Troya se fija el soneto IV ( «El que soberbio a no temer se atreve...») Pero mientras en III la ruina de Cartago quedaba compensada con su posterior gloria, aquí -en fino contraste entre las dos piezas contiguas- es el colofón del pasado encubrimiento [...]. Pero es que Argujo ha manejado una intención evidente: los sonetos II-IV tratan de la decadencia de lo encumbrado y significativa es por eso la apertura con soberbio de III y IV ${ }^{72}$.

A Arguijo ha prestado particular atención F. J. Escobar Borrego (2017) explanando la variada integración de las fuentes clásicas y la retórica visual. Con ejemplar planteamiento expone las complejísimas relaciones entre mitología y antigüedad clásica en los círculos artísticos y eruditos de Sevilla, y desde su aquilatadísima y refinada erudición, con exhaustivo aparato de constataciones documentales y renovada lectura, llega a conclusiones que, a mi modo de ver, establecen un punto de anclaje esencial para todo lo referente a la lírica sevillana de la época ${ }^{73}$ : «A la vista de los datos expuestos - indica- se hace evidente poner de relieve la inclinación estética de Arguijo por el cauce genérico-métrico del soneto, por lo general, de calado epigramático y preñado de contenido mitográfico, ya sea pagano o bien espiritual. A estos rasgos conceptuales y estilísticos cabe añadir, además, una acentuada escenificación lirico-simbólica y una visible fragmentariedad visual en sus versos. Como tampoco habrá de faltar en nuestro autor una notable pervivencia de la

a evocar exclusivamente la grandeza de Tartessos. No aparece, por tanto, ningún elemento de la descriptio tópica que reclame una comparación entre pasado y presente. El único que es portador de oscuridad, de connotaciones de muerte y abismo es ese olvido, situado junto a se levante en un movimiento de recuperación y recreo de una época de gran belleza y trascendencia histórico-mítica [...]. Tartessos establece de nuevo una relación básica con el aere perennius horaciano» (Cabello Porras, 1981: 324-325).

72 Arguijo (2004: LIX-LX). Los textos poéticos correspondientes en pp. 5-10. Véase también Pozuelo Calero (2008a: 181-192 y 2008b: 61-93) y Beltrán Fortes (2017: 126-132).

${ }^{73}$ En un plano de construcción teórica, sus ejemplares indagaciones vienen a correlacionarse estrechamente con el apartado que L. Bolzoni dedica a «Come tradurre le parole in immagini: memoria e invenzione», en especial en los paragráfos que interactivan «Memoria delle immagini e repertori iconologici», «Il testo come edificio» y "Come tradurre una narrazione in un ciclo di immagini» (1995: 187-192, 198-202 y 217-220). 
tradición retórica, asimilada en la ratio studiorum de los jesuitas, con recursos como la evidentia y la figuración mitológica a partir de estatuas marmóreas, por lo que resultan de gran importancia la apelación sinestésica a los cinco sentidos, la materia y las texturas en general, como se estudiaba, en fin, en los tratados de artes más conocidos de la materia. Además, se percibe en Arguijo cierta inclinación a la aspereza fónico-simbólica, con un efecto sonoro, la perspectiva o prospettiva visual, en concordia con destacados teóricos italianos de la época, e incluso una suerte de percorso della visione o itinerario visual como atractiva invitación al lector [...]. Es más, se justifican desde tales directrices conceptuales la apropiación por parte de Arguijo de un simbolismo plástico e iconográfico que estrapola al texto poético teniendo en cuenta recursos técnicos como la phantasia y la enargeia, la écfrasis y la retórica visual mediante materiales sustentados sobre el claroscuro, el cromatismo y otros recursos técnicos ${ }^{74}[\ldots]$. Arguijo, en los círculos de elite cultural en los que estaba integrado, no se limitó, en fin, a un montaje interdisciplinar entre la pluma, el pincel o el plectro bien temperado, sino que contó, en paralelo, con una especial inclinación por el coleccionismo, la arqueología clásica, las antigüedades y otros dominios afines, que evocaban, en fin, el recuerdo de lo que fue la tradición grecolatina en todos sus aspectos culturales posibles, teniendo siempre como un leitmotiv o ritornello la mitología, de ahí que una de las constantes temáticas en la poesía de Arguijo asociada a las fuentes clásicas venga dada por la tópica de las ruinas y la fragmentación visual como se comprueba con la imagen de los "mármoles rotos" del soneto II que conllevaba una interpretación moral [...] o el soneto LXVI (A las ruinas de Itálica) en la más acendrada tradición poética sevillana, de Francisco de Medrano, Francisco de Rioja o Rodrigo Caro» (Escobar Borrego, 2017: 97-99) ${ }^{75}$.

${ }^{74}$ Véase en el mismo sentido de lo explicado, con erudición brillante, por F. J. Escobar, mi análisis del soneto de Arguijo «No los mármoles rotos que contemplo...» como «manifiesto hibridismo» donde «la mediatización de la estructura por la cadena temática conlleva una función diferenciada en el sentido de la inducción neopetrarquista. La tectónica de Superbi colli conforma el eje referencial del discurso como reflexión interiorizada sobre la desgracia en amor, aunque la fórmula retórica elegida, una variante de la apostrophatio ad nos permite delinear con más intensidad la aplicación al propio sujeto productor [...]. La novedad nace en este poema de Arguijo de la función negadora de la propia cadena temática, estableciendo un significado inteligible solo desde esa perspectiva metatextual. Con la organización que delinea la sistemática negación se produce una dual alternativa dialéctica frente a la vanitas sustanciada en las ruinas y que magnifica en la "memoria" lo inconmensurable de su desgracia, la imposible satisfacción de una voluptas dolendi ("el mal que nunca templo") impermeabilizada a lo extrasubjetivo; frente al engañoso recurso de una esperanza meramente fantástica, la sentencia de la razon a transfigurar lo externo en consolatio» (Lara Garrido, 1999b: 259-260).

75 Las publicaciones de Escobar Borrego son tan numerosas como esenciales para entender el ambiente humanístico sevillano que surge bajo el magisterio de Mal Lara y sobre el que versan J. M. Rico García (2001: 23-42) y B. López Bueno (2001: 67-72; 2010: 487-512). Además 
De Escobar Borrego se acoge al volumen reseñado con eruditísima notación que relaciona las ruinas y el apuleyanismo en la nueva Roma de mediados del siglo XVI, teniendo como fondo al Petrarca lector de El asno de oro. Desde el humanista Alonso de Fuentes ${ }^{76}$ se inicia el trayecto que conducirá mediadoramente a Juan de Mal Lara (desde La Psyche al Hércules animoso), por «afinidades metodológicas» también con otros eruditos «interesados en la pervivencia del mundo clásico, con el apuleyanismo y las ruinas como arqueología del pasado». El poeta de Arezzo, invocado como auctoritas a cuyo trasluz «entra en diálogo intertextual» con el momento narrativo de El asno de oro, que le permite «remozar un poema de cotidianeidad, en consonancia con la filosofía natural de sesgo aristotélico por la que aboga en su obra». Un episodio fascinante de la «arqueología de las ruinas [...]. Se propuso ofrecer así unas sugerentes impresiones de esos espacios de la Antigüedad clásica con alusiones al Coliseo y el Anfiteatro, al tiempo que consideraba herederas de ese glorioso pasado Roma y Venecia, acompañados in illo tempore, como una nueva Roma y las ruinas de Itálica junto a los emperadores Trajano y Adriano, elogiados tanto en La Psyche y el Recibimiento de Sevilla a Felipe II como en el Hércules». En definitiva «como si se tratase de un sueño con las ruinas arquitectónicas del pasado y un paseo por las ruinas del Foro, tuvieron a modo de protohistoria el binario ruinas y apuleyanismo en la nueva Roma del siglo XVI, con Petrarca en calidad de lector e intérprete de El Asno de Oro» (Escobar Borrego, 2019: 101-111).

Argumento central y piedra de toque del volumen reseñado es la Canción a las ruinas de Itálica de R. Caro ${ }^{77}$. En su prólogo al volumen, L. A. de Cuenca

de su magna edición del Hércules animoso (narración épico-alegórica en que se acompasan las hazañas del emperador Carlos v con los del héroe legendario), que se encontraba manuscrito en la Biblioteca de Ajuda, véase F. J. Escobar Borrego (2000: 133-155; 2004: 39-98; 2007: 1-33).

76 Alonso de Fuentes procede metodológicamente en virtud de su paradigma científico-conceptual que viene a anticipar, años antes, el de Mal Lara en su Filosofia vulgar. Acaban realizando un amplio repaso por la tradición clásica, «de notorio interés para la Nueva Roma de mediados del xvi, en la que no faltó la tópica de las ruinas legendarias entre la ficcionalización de la fábula mitológica y la historiografía de la antigüedad grecorromana. Lo hizo, de hecho, gracias a personajes como Teseo, Pólux, Alejandro Magno, Jerjes con su extraordinario puente o Nabucodonosor y sus huertos pensiles, en su apunte a los "siete milagros del mundo" [...] entre otros mirabilia concebidos a modo de ruinas por carecer del propio sitio donde fueron fabricadas» (Escobar Borrego, 2019: 104).

${ }^{77}$ La valorativa del poema de Caro se instaura muy pronto, con las poco conocidas reflexiones que hizo J. Marchena en sus Lecciones de filosofía moral y elocuencia y que creo obligado reproducir: «El afecto que la célebre Canción a las ruinas de Itálica anima es la melancolía filosófica que las vastas reliquias de los edificios en que se ufanaba el humano poderío, en los mortales infunden. Tremendos documentos de la flaqueza del hombre y la fuerza de la naturaleza, el moho que sus derribadas columnas carcome, el amarillo jaramago, que en los fragmentos mal seguros de sus medio allanadas paredes crece, nos están señalando la honda sima que a nosotros, las obras 
ha releído «con fruición la canción A las ruinas de Itálica» y esboza el elenco de redacciones del poema y su filiación, para lo que sigue la recopilación de P. Blanco Suárez: «Las dos primeras tienen fecha segura: el mismo Caro afirma que escribió su primera versión en 1595, a los veintidós años, a raíz de una excursión a Itálica [...]. La segunda versión, por estar incluida asimismo en el Memorial, fechado en 1604, hubo de ser escrita entre esa fecha y la anterior. En lo que atañe a las otras dos redacciones originales y a la copia hecha en Sevilla por Gallardo no hay modo de fecharlas. Pero sí puede establecerse un orden cronológico entre ellas. La de Carmona es la que más se aproxima a las dos de Memorial; seguían a la de Carmona la copia de Gallardo, que tiene unos versos comunes ella y otros con la versión vulgata de la Biblioteca Nacional madrileña, que sería la quinta y definitiva». Por lo que hace al proceso redaccional mismo, L. A. de Cuenca apunta que «las dos primeras redacciones son meros tanteos, y la canción de Itálica surge con toda su belleza en la tercera, la de Carmona. La distancia entre esta y las anteriores es tan grande que ha llegado a pensarse si no nos faltará por conocer un eslabón. De no ser así, el autor había trabajado durante mucho tiempo en el poema hasta decidirse a escribir una nueva versión. De la tercera redacción a la quinta y definitiva hay menos trecho estético, pero se dan felices modificaciones tan importantes como las de los versos 1-2, que han pasado a la memoria colectiva como "Estos Fabio, ¡ay dolor!, que ves ahora / rüinas que esparció rústico arado" de la redacción de Carmona» (Cuenca, 2017: 13-14) 78 .

nuestras, nuestro vicios y nuestras virtudes nos ha de sepultar un día. La aniquilada potencia del pueblo-rey, que fundó a Itálica, los soberbios edificios de esta colonia, la gloria de sus hijos, señores los unos del universo, ilustres otros por sus tarcas literarias, todo se retrata con viveza a la muerte del autor. Las regaladas termas, el vasto anfiteatro, los palacios que habitaron los Césares, hijos de Itálica, las piedras que publicaban sus hazañas, todo ha sido víctima del tiempo y de la muerte» [...]» (II, pp. 385-386). Y tiene un refrendo definitivo en el joven Menédez Pelayo: «Para Rodrigo Caro [...] lo más grande, lo más augusto que cubre el suelo son ruinas romanas: entre ellas vive y de ellas canta y a ellas lo refiere todo [...] cuando vuelve los ojos a aquellos superbi avanzi dell'antichità que dejó sembrados como despojos triunfales de su paso el pueblo rey, su fantasía se enardece y adquiere segunda vida intelectual. Un fuste, un capitel, un trozo de columna, los despedazados restos de unas termas o de un anfiteatro, una inscripción medio borrada [...] le hablan con voz elocuente y misteriosa, no entendida por la mayor parte de los humanos. Él comprende lo que dicen, al espíritu que sabe descifrarlas, "las altas murallas cubiertas de hierbas y de monte", "las anchas plazas y pareadas calles, ya sin habitadores" [...]. Y esto que con tanta viveza y $\tan$ soberana energía siente en prosa [...] lo traduce luego en versos inmortales, obedeciendo a una inspiración casi fatal, que le hace poeta en el único género en que podía serlo y que le obliga a derramar todos los tesoros de su alma [...] en una sola composición, de la cual son desperdicios y residuos todas las otras» (1883, pp. XxIII-XXIV). También Motta Salas (1948: 277-290), García Bellido (1951), Étienvre (1979: 31-106) y La Beira Strani (1987: 69-84).

${ }^{78}$ Incluso en Caro, la ruina es «una categoría anticlásica», y como explica S. Marchán (1985) «la ruina no podía ser reconocida por la estética clásica a no ser desde la trasgresión, desde lo 
El artículo que, a juicio de Sánchez Jiménez, «funge de introducción conceptual al volumen por la profundidad de las ideas que propone y la amplitud de su corpus», el debido a P. Ruiz Pérez, se centra parcialmente «en analizar cómo las variantes de las diversas versiones de la Canción a las ruinas de Itálica de Rodrigo Caro revelan un cambio de actitud en la contemplación de las ruinas que procede de una progresiva implicación del sujeto en el paisaje descrito» (Ruiz Pérez, 2019: 28). En efecto, en el citado estudio se dedica al asunto el apartado «El paradigma: la invención de las ruinas» que comienza señalando la unanimidad con la que se considera «como el texto que por antonomasia materializa el subgénero de poesía de las ruinas y constituye su realización más culta». Esto ocurre en referencia a la versión definitiva del poema, con la que «se impone una incuestionable eficacia, fruto de la feliz comunión de retórica y afecto, otra manera de decir que el movere lleva los afectos del lector a identificarse con los de la voz lírica». Pero no se trata de un afortunado hallazgo sino del resultado de una lenta labor de reescritura cuyas «huellas textuales, a modo de ruinas inversas, nos permiten reconstruir con bastante precisión», de forma que «a modo de espejo, la disposición en serie cronológica se convierte también en un modo de deconstrucción de la obra por debajo de su aura, dejando en el análisis marcados los elementos constitutivos de lo que le llevará a alcanzar su valor paradigmático» (Ruiz Pérez, 2019: 36-37). El Memorial de la villa de Utrera, una evocación arqueológica, documenta los momentos iniciales y los impulsos de la curiosidad humanista: «Adquirida con la lectura, la noticia llega con el aura del prestigio y un cierto principio de moralidad [...]. Es de base intelectual y letrada el deseo de ver, entre la pulsión escópica y la voluntad de comprobación [...]. La visión no remite a una dimensión plástica sino discursiva, y la realidad difumina

inacabado y lo fragmentario, desde un retorno de lo reprimido, que no es sino la propia matriz de una condición anticlásica. No debe sorprender, pues, la carencia de una estética de la ruina en la doctrina clásica [...]. Como acontece con aquellas esculturas mutiladas en algunos de sus miembros, ante la contemplación de las ruinas el sentir clásico no puede por menos que verse afectado por el hecho de que las partes percibidas, presentes, innovan y relacionan a las ausentes» (pp. 5-6). Con más contundentes argumentos, P. Spedicato (1986: 79-80) escribe: «Un discorso più specifico sulle rovine della letteratura non può comportare una mera individuazionerivisitazione dei suoi topoi rintracciati in uno o più periodi della tradizione letteraria, ma piuttosto il considerare la letteratura un inmenso corpo rovinato essa stessa, un panorama fitto di rovine sovrapposte dal tempo ruens (Orazio) rovinante o precipitante, in nome di un'idea non tradizionale o rassicurante della comunicazionne letteraria, in vista di uno statuto destabilizzante e critico di essa [...]. Senza voler affrontare pienamente le implicazioni tra queste strategie [...] si intende qui delineare un' utulizzazione critico-filosofica e tendenzialmente destructive del tema della rovina, non quindi solamente rimemorativa, contemplativa e a suo modo esteticamente edificante». No creo traicionar el espíritu de las contribuciones generales de A. Sánchez Jiménez o P. Ruiz si las incardino en este propósito general de redicción y reinterpretación de la bibliografía canónica. 
su condición inmanente para asumir la de un texto, una voz que habla al pensamiento, obligado a alargarse para considerar la lección, la moralidad de los restos de la famosa Itálica. El impulso genera el movimiento hacia el lugar de las ruinas y la contemplación de las ruinas provoca el arranque lírico de la canción» (p. 38).

Una vuelta al texto del Memorial nos permite recomponer el proceso de reflexión, pues «se produce con bastante exactitud el movimiento intelectual que sigue al desplazamiento físico del anticuario sevillano en busca de las ruinas en su doble camino "por la orilla del río", real e iniciático». Si a la mirada sigue la reflexión, el pensamiento se levanta hasta «considerar una materia de orden metafísico ("la fuerza irreparable del tiempo") que incuba por igual a lo personal y a lo histórico [...] las ruinas se conectan en signos que trascienden su propia materialidad». Con la labor limae ${ }^{79}$ el trabajo del poeta parece enfrentarse «al efecto devastador del tiempo, devolviendo a las ruinas, a manera de espejo invertido», lo que le ha quitado la devastación de su original prestancia. Así parece apreciarlo en la comparación mínima de una estrofa inicial en tres de las versiones, aduciendo como correlato que, incluso, de ello podría resultar «la formulación de una poética de las ruinas». Destacan en las líneas de reescritura «el borramiento de la erudición, la desaparición del edificio como referencia de solidez, la presencia de la soledad y la percepción del tiempo, la consideración de las reliquias (en sentido sacro-profano), y la imagen de la torre derrumbada, con el asolador paso de lo vertical a lo horizontal, de la soberbia al desmoronamiento. Y sobre todos ellos, una retórica en la que la nueva écfrasis cede espacio a los efectos de lo patente y de lo patético». Se insiste luego en los efectos del movere, en el valor poderoso de la evidentia, la fuerza de la enárgeia que carga los versos de simbolismo y trascendencia. Borrar lo descriptivo en un subgénero sobredeterminado por la pictura supuso un giro radical en la tradición: «Caro supo ver con claridad que la ruina es

\footnotetext{
${ }^{79}$ Una ausencia bibliográfica resaltable con relación al poema de Caro es la monografía de L. Gómez Canseco (1986), donde, aunque centrado en el estudio de Varones insignes en letras (pp. 179-232), dedica unas páginas relevantes a la Canción estableciendo cómo «está construida desde los presupuestos de la oratoria, haciendo un uso continuado de la misma y los loci communi [...]. Aparece como una muestra de contención en la forma y en el sentir, muy acorde con el paradigma senequista que animaba, en buen número a los autores sevillanos del XVII». «Rodrigo Caro — ha asegurado poco antes - adopta las guías del peregrino de la ciudad [...]. La primera estrofa del poema corresponde al exordio en la construcción del discurso. La segunda y tercera estrofas alcanzan el primer clímax con la descripción del anfiteatro [protagonistas de la tragedia en el sentido de la Poética de Aristóteles serían los emperadores, representando la acción desarrollada en el anfiteatro] hasta aquí la narratio de nuestro discurso. El autor-orador llama de nuevo la atención de Fabio — su público—y recapitula sobre los argumentos ya exprimidos en la confirmatio de su oración; el segundo clímax se alcanza con el recurso de los ecos. La conclusio corresponde a la última estrofa, en la que se pretende dar un sentido cristiano a la composición, ajustándose al modelo del panegírico de la ciudad» (pp. 59- 60).
} 
menos una presencia que una ausencia, menos un objeto material que un vacío en torno al mismo. Como los moldes de los cuerpos extraídos de las cenizas de Pompeya, la ruina recorta el perfil de una oquedad, de la solidez que se disuelve en el aire, de la desaparición». Junto al cambio del edificio por su antítesis (el campo y la soledad) el otro cambio fundamental inducido por Caro es la renuncia a la mera función de "guía", sustituida por «la radical experiencia subjetiva en que consiste la contemplación» y «a su lado, como refrenando el pathos, la presencia del interlocutor desplaza el sufrimiento al pensamiento, la queja a la reflexión, introduciendo, con la amistad horaciana, la consideración moral ante el discípulo, el mismo elegido por Fernández de Andrada y con similar mensaje (neo) estoico» (p. 41) ${ }^{80}$.

Algunos elementos se habían venido desplegando en la serie textual del Superbi colli, como se ejemplifica con un conocido soneto de Rey de Artieda $^{81}$. Pero esta perspectiva se asienta definitivamente en Caro «ahora con

${ }^{80}$ El mejor análisis de la construcción del poema es el debido a Gómez Canseco (1986): «Desde el elogiadísimo hipérbaton inicial — tomado de Propercio- el poema adquiere un tono perfectamente clásico. El autor se dirige a Fabio, que no aparece hasta la tercera redacción, transformándose el monólogo originario en discurso, para el que Caro hace uso de una deixis propia del orador. La primera estrofa se estructura por el contraste entre pasado y presente, descubriéndose una división por pares de versos en los que el primero se refiere al pasado y el segundo al presente [...] en la grandeza de Itálica entraba ya su destrucción: en el pasado estaba implícito el presente. La presencia del anfiteatro provoca el primer movimiento climático del poema junto con el ubi sunt en versión clásica. Subyace la tópica asimilación de la vida a un teatro, en la que ahora el héroe es el tiempo [...] cierra la tercera estrofa uno de los tópicos preferidos por Caro, el de la consolación: aun las piedras, más fuertes que los hombres, sucumben a la obra del tiempo. El poeta-orador vuelve a llamar a Fabio, a quien su discurso, como primer objeto debe conmover. Resume sus argumentos y pasa a un nuevo tópico, el sobrepujamiento. Comparable a Roma, Troya y Atenas es Itálica, cuya ruina es suficiente causa de dolor [...]. En la estrofa quinta, que enlaza con la anterior por la pregunta retórica, aparece una de las figuras mitológicas preferidas por Caro, el genio de la ciudad [...]. Esta figura mítica posibilita el uso de otra figura retórica, el eco, con excelentes resultados en el poema, convirtiéndose en el segundo momento climático. Con la última estrofa el poeta cambia de interlocutor y se dirige a Itálica para que dé señas de las reliquias de su primer prelado Geroncio. Caro intentó darle un sentido religioso, ajustándose así al modelo panegírico de las ciudades» (pp. 160-162).

${ }^{81}$ Rey de Artieda en «Sacros collados, sombras y ruinas» vendría a caracterizar «los loci del arquetipo del poema de ruinas». En él, el tiempo «con tres secuencias léxicas» se impone «como el elemento distintivo, motor del paso de fábrica a ruina; su efecto solo es compensado por la memoria cuya metonimia o materialización la conforman los sacros collados»». También del superbi colli se mantendría «la marca con que el soneto continúa la estructura y la retórica del soneto petrarquista». La descripción o narratio ocupa los dos cuartetos y el primer terceto «dejando para la última subestrofa la consideración subjetiva. En su espacio lo que domina es la idea del tormento repetido de Castiglione a Rey de Artieda y característico de la sentimentalidad petrarquista» (Ruiz Pérez, 2019: 42). También la equiparación entre las ruinas de Troya y el estadio del amante, que se pondera venciendo o sustituyendo a aquella, tiene larga ascendencia y descendencia. De Jorge de Montemayor es este soneto que publicó Fr. J. Zarco Cuevas de un Ms. Escurialense, en versión que presenta numerosas variantes (1933: 429): «No fue la linda Elena 
un giro de gran repercusión», explorando «lo que en el soneto de Castiglione era una enorme y codificada elipsis». «Entre la atención ecfrástica a las ruinas y la narcisista contemplación del tormento propio, la actitud moral del sevillano desarrolla un argumento reflexivo de carácter general [...] a partir de la experiencia, tan intelectual como afectiva, del esplendor perdido». Puede hablarse con ello de la «invención de las ruinas» en un sentido etimológico, pues «asistimos a una verdadera construcción imaginaria en que la realidad de una presencia tiene menos peso determinante que la fijación de unas imágenes». La saga de Castiglione encuentra en Caro «el espacio necesario para su despliegue y conformación definitiva, entre la panorámica y la visión de detalle. Si se conceptualiza en términos de pintura (y no pueden menos que recordarse los «lienzos de Flandes» gongorinos), la Canción ofrece un locus pictus (con la amplia semántica del fingere latino). «Bajo el paraguas de su consideración como reliquias las ruinas sustituyen el atractivo o la repulsión del despojo, por la consideración del valor sagrado de aquello a lo que remiten a modo de sinécdoque. Cuando la moral cristiana desplace a la estricta arqueología humanista, el referente de la ruina ya no será el edificio y su momento de esplendor, sino el avasallador poder del tiempo, su poder destructor, pero también su valor de aviso y escarmiento» (Ruiz Pérez, 2019: 44).

El análisis exento de una parte mínima de tres de las cinco versiones de la Canción de Caro, puede encontrar apoyaturas - y alguna matización- si se complementa con otras notas que se desprenden del conjunto de su obra, y más estrictamente del total de las recreaciones del poema. Como recuerda $\mathrm{M}$. Morán Turina, en sus diversos escritos Rodrigo Caro «nos ha dejado una crónica impagable de la intensidad y ritmo con que fueron desapareciendo las ruinas de Itálica desde que las visitara por primera vez en 1595, cuando solo tenía veintidós años y estudiaba en la Universidad de Osuna, hasta 1634 en que dio cuenta de su última visita a la ciudad». Cuando en 1604 descubría las ruinas vistas años atrás tan solo resultaban reconocibles «dos edificios con su antigua forma. El uno es una plaza de armas o atarazana, toda de ladrillo y bóveda [..., el otro] un anfiteatro o circo, y este me pareció obra de más antiguo y puramente de romanos [...]. Más adelante un poco hay otros grandes destrozos, y allí quieren decir o imaginar debió de ser algún templo, porque las ruinas muestran haber sido obra magnífica [...] y también se puede ver parte de su acueducto» mientras que en el resto de la ciudad «la forma de las calles y casas

celebrada / por su sola beldad y hermosura, / ni solo fue de París la ventura, / ni Troya sólo fue la desdichada. / Si Elena fue perfecta y acabada / señal fue que de ti nos dio Natura, / que no fue perfección mas que figura / do tu sola beldad fue figurada. / También figura el pensamiento / que en tu beldad osó ser empleado / con gran sobra de amor y atrevimiento, / pues ¿quién Troya será sino el cuitado / que está continuo ardiendo, y tan contento / que no quiere acabar de ser quemado?». 
no se parecen con distinción». Tras la devoradora riada de 1603, después de las extracciones de piedras y ladrillos que se llevaron a cabo para la restauración de Santiponce, el panorama que recogía en sus Antigüedades y principado resultaba más desolador: del anfiteatro «destruido en su mayor parte» solo era reconocible la forma que tuvo, de los restos del templo «ya hoy no queda casi nada» y aún quedaba menos de aquel otro edificio «atarazana de ladrillo y bóveda» que en 1595 permanecía entero (Morán Turina, 2010b: 160-163).

Más interés encuentra Morán Turina en los relatos personales de la visita primera de Caro y de la epístola de Hernando de Soria, porque «los recuerdos de uno y otro tienen en común» la reflexión sobre el poder irrebatible del tiempo. Eso los hace «especialmente interesantes y los diferencia de las habituales descripciones de ruinas que encontramos en los relatos de los viajeros y en los libros de anticuarios e historiadores locales: son recuerdos contados en primera persona» y a sus autores «les interesaba menos la situación y el aspecto de los edificios que el estado de ánimo de quienes contemplaban aquel desolador espectáculo sobre «la fuerza irremediable del tiempo», desde idéntica posición fatalista frente al imparable avance de enemigo tan fiero». «Intento en este tratado - escribe R. Caro al comienzo de sus Antigüedades- conservar en la corta memoria que mereciesen y alcanzasen mis escritos, lo que resta de las antigüedades de Sevilla y su tierra, antes que del todo se desaparezcan y acaben en manos de ese poderoso contrario, el tiempo, que cada día la va gastando y consumiendo». Morán Turina (2010b: 163-166) eleva estas frases a una verdadera declaración de principios que «es, al mismo tiempo, una amarga aceptación de su derrota y la verbalización más clara de la mayor paradoja en la que se vieron envueltos los humanistas anticuarios del siglo»: estaban convencidos de que no habría materia más perdurable que la «memoria de las piedras», pero a su vez acabaron confiando en la supervivencia de un vehículo tan frágil y perecedero, tan rendido al tiempo, como la escritura.

Sabido es que de la Canción a las ruinas de Itálica se conocen cinco redacciones, «cada una conservada en distinto y único manuscrito». Desde que Rodrigo Caro, escribió A. del Campo, glosando en parte a Menéndez Pelayo, «todavía un muchacho, pero con aguda sensibilidad para la percepción de lo temporal (1595) contempló por primera vez las ruinas de Sevilla la Vieja quedó tocado para siempre. Su vocación poética —ipor qué dudarlo? — nació allí. También allí encontró el tema de sus versos. Pero estos, lejos de calmar su ansia de expresión le trajeron una insatisfacción incurable. ¿Quién sabe cuántas veces reescribió el poeta la Canción? Diríase que como las ruinas que cantaba, también ella vivía en permanente estado de transformación». Y como muestra expresiva cita en nota un fragmento de las Antigüedades donde Caro consigue infundirnos sobre el tema de las ruinas «un estremecimiento de calidad estética»: «En medio de aquellas lastimosas reliquias que a pesar de los días aún 
permanecen en el despoblado de lo que hoy llamamos Sevilla la Vieja, aún no están acabadas de sepultar sus grandezas, y en el silencio de aquel antiguo pueblo, al más divertido caminante da voces desde aquellos siglos la fama de sus ilustres hijos y pide para aquellas despedazadas reliquias admiración y respeto, publicando que allí fueron las primeras cunas de Trajano, Adriano y el grande Teodosio» (Campo, 1957: 49-50). Analizando el fundamento de la «realidad cultural» de este último aserto, encuentra cómo Caro solo tuvo que acudir al difundido Theatrum orbis terrarum de Abraham Ortelio, como explica en las citadas Antigüedades: «Item a la Italiense, dicha por la población de italianos, nobilísima patria no solo de ciudadanos más de emperadores Romanos: está seis millas de Sevilla a la otra parte de Guadalquivir. Fue antiguamente muy venerada por amor del santo obispo Geroncio, mártir y patrón della. Han salido de la ciudad al mundo Trajano, Adriano y Teodosio, Augustus Óptimos Máximos señores del mundo. Comúnmente se llama Sevilla la Vieja, en que se ven grandísimas ruinas, que apenas ahora parecen; ejemplo miserable de las cosas humanas, y tanto más de sentir por el magnificantísimo y hermosísimo anfiteatro que hoy se ve arruinado y hace más triste la memoria de su antigua magnificencia y grandeza» (Campo, 1957: 99-100).

El problema textual de la Canción constituye un capítulo crítico de larga y compleja argumentación (Caro, 1947), en la que aparece como eslabón endeble la socorrida y popular acogida de las versiones en el volumen del P. Blanco Suárez (aparecido por primera vez en 1933 y luego largamente reeditado). Poco después, E. M. Wilson, en un artículo que supuso el primer enfoque realmente filológico del asunto proponía, partiendo de las anotaciones desiguales de A. Fernández Guerra, que sus propuestas de fechación de las diversas versiones (A: 1595; B: 1603; C: 1608-1612; D: 1630-1647; E: 1614) sólo podrían ser aceptadas en parte (sería exacta la de A; admisibles las de B y E, pero faltas de base las de C y D). «El orden de las estancias es el mismo en C, D y E, si prescindimos del hecho de que la penúltima estancia de $\mathrm{C}$ es casi totalmente distinta de las correspondientes de los otros dos poemas. A consta de cinco estancias y un envío. En B, el poeta agregó una estancia entre las $2^{\mathrm{a}}$ y $3^{\mathrm{a}}$ de $\mathrm{A}$ y suprimió el envío. De $\mathrm{B}$ a las últimas versiones se altera el orden. La $3^{\mathrm{a}}$ estancia de B aparece como $4^{\mathrm{a}}$ en C, D y E, la $4^{\mathrm{a}} \operatorname{como} 5^{\mathrm{a}}$ y la $5^{\mathrm{a}}$ en el lugar de la $3^{\mathrm{a}}$. Hay también otras alteraciones de orden; la mitad de la estancia $3^{\mathrm{a}}$ de $\mathrm{B}$, rehecha, se coloca en la estancia $5^{\mathrm{a}}$ (en C, D, E), en lugar de en la $4^{\mathrm{a}}$ y la referencia a Silio Itálico se encuentra en la $3^{\mathrm{a}}$ (en CDE), en vez de en la $5^{\mathrm{a}}$ donde debiera haber estado» (Wilson, 1936: 380-381). También planteaba E. M. Wilson «cómo cambia la construcción del poema en los tres manuscritos A, B y E. En la primera estancia de A se nos expone el tema. Caro nos muestra las torres y murallas. La segunda estancia describe el anfiteatro, con el cual asocia el concepto de tragedia y particularmente la tragedia del tiempo. La tercera estancia 
se aparta del tema, refiriéndose al Guadalquivir y a Silio Itálico. Esto le lleva, en la estancia siguiente, a enumerar los héroes por los que Itálica fue celebrada. En la quinta estancia aparece la idea de las cosas eternas que sobreviven puramente, la grandeza terrenal y la vida eterna personificadas en San Geroncio. Finalmente, el envío resume los sentimientos que despierta Itálica "despoblada y de conceptos llena". En B se verifica un notable cambio: una nueva estancia se introduce entre la que describe el anfiteatro y la que se refiere a Silio Itálico, y se suprime el envío. En ambas versiones el orden es mecánico y podría alterarse en ocasiones sin afectar en mucho a la esencia del poema. $\mathrm{E}$ es diferente. La primera estancia nos expone el tema: la plaza, los templos, el gimnasio y las termas. Esta introducción conduce, como en las versiones anteriores, a un clímax natural: la visión del anfiteatro, la más impresionante de las ruinas de Itálica. La idea de tragedia se asocia fácilmente a la contemplación de una ruina o de un teatro: más fácil es que se asocie a la contemplación de un teatro en ruinas [...]. Pero la morada de los Césares es ahora madriguera de lagartos; es la tragedia del tiempo. Aquí hay una pausa en el movimiento del poema. En la cuarta estancia desandamos lo andado para volver a la misma manera poética del principio. Se invoca de nuevo a Fabio y se nos hace recordar la ciudad toda que llega a transformarse en símbolo de la grandeza de la civilización antigua y de su subsiguiente caída, par de Toya, Grecia y Roma. La quinta estrofa es un contraste retórico; es cierto que Grecia y Roma son los motivos que se nos hace contemplar, pero Itálica por sí sola es más que suficiente para despertar nuestra melancolía. La última estancia relaciona la santidad de Geroncio con los destrozos del tiempo, de los que escapa. El plan de E es muy superior a los de A y B. Su orden nos traslada natural y efectivamente de una a otra estancia, y el poema constituye un conjunto orgánico, aunque su desarrollo sea más propio de un discurso que de un verdadero poema» (Wilson, 1936: 381-382).

La edición crítica y anotada de las cinco versiones de la Canción llevada a término finalmente por J. Pascual Barea (2000: 135-161) introduce una lógica enumeración de las mismas (I, II, III, IV y v) y dispone con una visualización complementaria de las diferentes secciones, cómo y en qué grado va evolucionando la escritura poética de Caro en la dispositio y realización textual. Así se hace posible una lectura comprehensiva y directa del proceso compositivo en su totalidad. En todo momento Caro alcanza una alta realización implicadora entre la voz lírica y la retórica de los afectos que apenas contiene elementos expletivos. El aspecto es más imperfectivo que imperativo y se realiza mediante una suma integrada de epanalepsis, evitando las rectificaciones sobre verdades universales. Carece la canción casi por completo del recurso a la epanortosis (más que a rectificaciones se asiste al afloramiento de las variaciones enfáticas mediante la epexegesis y a la repetición de términos sin 
intervalo calculado). De alguna manera el discurso traduce la expolitio de un cuadro visual (pero también, a ratos, sonoro) cuya magia radical estriba en venir condicionado por un tiempo in fieri (el presente absoluto del contemplador que intermedia entre el tiempo in posse del significado y el tiempo in esse de la historia). Las relaciones entre los referentes de su locus pictus son homonexuales y están dominadas por la hipotiposis y el sinatroísmo, esto es por la expresión plástica de elementos de naturaleza abstracta (la identidad entre lo contemplado y lo predicado; correspondencia de términos careados y que vienen a ser correlativos) sin que se deje intervenir a la interrupción brusca del discurso por un silencio retórico. La reacción es ilativa y homoplana, sin que Caro se deje arrastrar nunca ni por un solo detalle xusivo (sobre todo de deseos que se hubieran debido cumplir en el pasado) ni por la frecuencia de erotemas en el movere efectivo (especialmente con el nuevo arranque coloquial y efusivo mediante el que al poeta, dirigiéndose a ese imaginario acompañante, $\mathrm{Fa}$ bio, quiebra la tonalidad arqueológica de las dos primera redacciones)».

Aunque la comparación con los arquetipos clásicos (Troya, Roma) permanece, es ahora del contacto directo con «aquel cadáver de la antigua ciudad» como se desencadena la lección lamentatoria: los restos de Itálica, cual seres con dolorosa conciencia de su deshacimiento tendrán el don de las lágrimas elegiacas. En la versión final un nuevo modo de contemplación vitaliza el ritmo y transforma la estructura de monólogo en discurso admonitorio (en ese paralelaje de «ruinas inversas» que ha sabido captar P. Ruiz). Fabio, increpado e invitado a reflexionar («iay dolor!, si tú no lloras»), es doblemente apelado por una voz que se dirige a su apex mentis conformando un verdadero teatro catóptrico con una sabia orquestación donde cada detalle ocupa su lugar, y enlaza, como también ha intuido P. Ruiz, lo patente a lo patético. La ciudad vencedora, ahora «campos de soledad, mustio collado» dice lo absoluto de la destrucción a la vista que recorre el espacio de la plaza, el gimnasio, las termas («espectáculos fieros a los ojos»), a la imaginada representación de la «fábula del tiempo» en el anfiteatro, ahogada la algarabía popular («voces alegres en silencio mudo») con la que siente el proceso mental un afianzamiento que en términos de óptica cabria definir como speculum anima. Este animismo de los objetos, portadores de un lenguaje sobrenatural, en los que resuena, cuando las tinieblas hacen opaca la reflexividad, el genio de Itálica, con voces que el eco transformará en gemidos, es el vehículo por el que el pasado renace en traducción a un signo moral de aplicación presente, amonestando contra las glorias mundanas (López Estrada, 1974: I, 135-138). De ahí que en el proceso redaccional se amplíen y maticen las referencias al tópico (bíblico y virgiliano) de la soberbia castigada: las torres rendidas a su gran pesadumbre, las estatuas que «Némesis derribó», con venganza divina a la intención icárica de trasponer sus límites. Componer y descomponer «a modo de espejo [...] en un modo 
de construcción de la obra por debajo de su aura» es también «recomponer el proceso de reflexión [...] en su doble camino por la orilla del río real e iniciático». Una especulación lucreciana que en términos ópticos significa desdoblamiento y cinemática, como en el mundo catóptrico de G. Della Porta o de Cardano donde el instrumento de prueba es siempre el espejo, pero no el directo, el comprobador de imágenes de Leonardo da Vinci, sino el speculum majus que presenta las cualidades con su conformación anamórfica: la contrariedad restituida y las visiones deformadas (las perspectivas corroídas) de un universo inexorable cuyo motor creador y destructor es el tiempo. El Tiempo que impide, finalmente, que ni con la imaginación la realidad evanescente (aunque sea de piedra) pueda ser restituida. Mundo catóptrico de la desesperación y el desconsuelo definitoriamente elegíacos.

P. Ruiz Pérez dedica un apartado («El cataclismo») a un soneto de Góngora de 1596 («Cosas, Celalba mía he visto extrañas...») que sin pertenecer al «paradigma ortodoxo de la poesía de las ruinas» nos permite acceder «acentuando», a «la sensación del cataclismo, el momento de fractura» ${ }^{82}$. El soneto va a la raíz y origen de la destrucción, y la referencia a «los días de Noé» viene

${ }^{82} \mathrm{La}$ lectura propuesta del soneto gongorino hay que enmarcarla en el hecho de que Escaligero como otros autores, había incorporado la tormenta como un tema casi obligado de la descriptio retórica, dentro de la cual entraría ese «impulso desmesurado hiperbólico» que subrayó E. Orozco Díaz en una clásica interpretracion. Desde los comentaristas clásicos hasta A. Carreira se han subrayado literales concordancias con Virgilio y Ovidio. B. Ciplijauskaité añade la tormenta (que en este caso apoyaría la lectura de P. Ruiz) del Génesis 7, 17-24. Véase la excelente anotación debida a Matas Caballero (2019: 594-595), con otras referencias a la tempestad destructora en la poesía áurea. La interpretación de P. Ruiz, propone un giro en la lectura del soneto en sí, aunque la idea de cataclismo cíclico del universo figura, por otra parte, en poemas del Barroco que quieren transmitir una idea del caos y de la infinita metamorfosis de la materia. Véase el siguiente fragmento de la Elegía en la muerte del Conde de Gelves don Fernando de Castro, debida a Bartolomé Leonardo de Argensola: «[...] El mármol que soberbio en su escultura / a los quïetos huesos de tu hermano / ofreció venerable sepultura, / ¿quién sabe si también fue cuerpo humano / en otro siglo y lo pasó la muerte / por su alterable variedad temprano? / El sujeto más sólido y más fuerte / entre la fuga de los tiempos medra / cuando en sorda materia se convierte. / Y otros verán como tenaz la yedra / lamiendo ofenderá los tersos lados / al epitafio de la ilustre piedra. / Los sepulcros también sienten sus hados / como las otras fábricas, mas antes / los montes mismos contra el tiempo armados. / Nuestros Pirenes, pues, o los Atlantes / de África, guarden minas, viertan ríos / en los senos avaros y arrogantes; / que del humor y del metal vacíos / inclinarán decrépitas las frentes / que agora ocupan árboles sombríos / [...]. Pasan los siglos a su fin veloces, / sin que del censo retroceda un hora / por tiernos votos ni vehementes voces. / La edad contra sus obras vencedora, / reserva para un último gemido / las mismas que alimenta y atesora; / porque origen mortal les fue infundido / cuando las dieron el lugar segundo / peso en su mismo centro sostenido. / La materia, en el tálamo fecundo / admitió los primeros himeneos / y elementos discordes sintió el mundo. / Desde entonces, con ansias y deseos, / que las formas le dan, volver porfía / al primer caos por íntimos rodeos [...]» (Leonardo de Argensola, 1974: 58-59). 
a ser su lectura «más que una directa referencia bíblica, una evocación de un momento telúrico de raíces antropológicas (y paleontológicas) y alcance universal». «Con una divinidad desatendida del cuidado de su creación, arrasada por la fuerza de las aguas, otra metáfora del tiempo, la tierra sucumbe y se muestra en ruinas, como la propia intimidad del sujeto que la observa, la pinta y se refleja en ella. Estamos ante la génesis de una nueva poética». Ante la violencia y alteración - indica tras insistir en lo que llama, frente al superbi colli, «el paradigma de Babel»— surge la extrañeza, presentada desde la perspectiva de una visión, de una suerte de travelling avant la lettre con que el hablante despliega ante su interlocutora el friso de la destrucción» (con tensiones semánticas como la que se produce entre entrañas «que remite a la introspección petrarquista», $\mathrm{y}$ 《extrañas» —ínsulas o violencias- «desplegados en el mundo exterior del individuo») (p. 47).

«Agua, visión y muerte. Cadáveres flotantes sobre un agua desbordada, sus componentes presentan en un verso de pura acumulación nominal los efectos de desintegración definitoria del orden arcádico y su precaria armonía». Violencia y mar le permiten remitir tanto al Polifemo como al «cataclismo original de la Soledad primera, cuando el peregrino emerge arribando a una playa en que los edificios no han cobrado cuerpo todavía o han desaparecido». Si en los grandes poemas gongorinos «no hay ruinas canónicas», en Góngora «la disolución de los componentes más reconocibles representa un ahondamiento poético y epistemológico en lo que las ruinas representan como vestigio de un tiempo y una historia en que el sujeto se encuentra completamente sumergido» (p. 50).

En el siguiente apartado («Las ruinas del Paraíso») P. Ruiz afirma que en la Antigüedad «hay una escasez de elementos susceptibles de configurar una poética de las ruinas». Tras el Renacimiento, la presencia en la égloga de la muerte «alcanza un relieve cualitativo con la aparición del motivo funerario (Et in Arcadia ego)» que «actúa a modo de espejo que recuerda la mortalidad y la temporalidad efímera de las cosas, incluida la precaria utopía arcádica». El escenario es un locus pictus «y supone la fractura de una armonía y el final de un idilio arcádico» que ya solo puede persistir en el artificio, que mezcla naturaleza y arte, del jardín. Mientras que en este es posible «levantar la casa del hombre», las ruinas, al imponer la metamorfosis representan «un espacio inhabilitable, el locus eremus». Así se oponen categóricamente espacio (jardín) y ruinas (poder de Cronos), sociabilidad y soledad. «En las ruinas, frente al equilibrio clásico del jardín, se emblematiza un sentir protorromántico». Y lo será en el momento en que al sentimiento de soledad deje de corresponder «al stilus más elevado, para cobrar, en clave de modernidad romántica, el 
sentido del estremecimiento de quien contempla, y en ello habrá de fundarse la nueva dimensión de la estética» ${ }^{83}$ (pp. 50-53).

El parágrafo que sigue se titula «Huerto deshecho: la mirada subjetiva», $\mathrm{y}$ comienza oponiendo cómo Góngora se recrea «en la violencia de una realidad alterada y subvertida con dimensiones sobrehumanas», al Lope que «encontraba en las ruinas de su jardín la metáfora de su situación anímica en clave de senil melancolía». El arrasado jardín explicita «la precariedad del paraíso soñado», la fragilidad —en definitiva- del correlato bucólico. El Barroco, en una especie de «sentimentalización de la naturaleza», sitúa su referente en «la más radical de la poética de las ruinas», una «dimensión conflictiva, que tiene la tormenta como paradigma y como causa privilegiada de la destrucción, del estrago y la ruina».

${ }^{83}$ En un modélico estudio J. Ponce Cárdenas ha identificado el «paisaje anticuario» gongorino con los Icones de Filóstrato, tras recordar la incidencia de estos desde Diego Hurtado de Mendoza a Gaspar Gutiérrez de los Ríos, deteniéndose en el Discurso de la comparación de la Antigua y Moderna Pintura dirigido por Pablo de Céspedes a Pedro de Valencia y donde «puede encontrarse alguna información sobre las excavaciones arqueológicas que el inquieto racionero cordobés habría conocido durante su estancia romana así como la admiración que sentía ante algunas composiciones musivarias en las que se reflejan elementos del mundo material». En ese entorno donde también resaltan Ambrosio Morales o Pedro Díaz de Rivas (considerado por Nicolás Antonio como «antiquitatis peritus», y autor de un volumen de inscripciones de la Hispania romana asi como de su estudio De las antigüedades y excelencias de Córdoba [Córdoba, 1627]), hay que entender el paisajismo gongorino, un paisaje anticuario en la tradición de los Icones cuya variedad y alcance precisa J. Ponce «La crítica contemporánea - sintetiza- ha individuado en la escritura de Filóstrato una cierta actitud de juego que aspira a reducir al lector por su capacidad de sugestión visual y por la belleza de la palabra persuasiva. El aspecto más propiamente lúdico de la descripción literaria de una obra de arte visual permitiría sostener que la écfrasis alejandrina e imperial no se limita únicamente a ser una descripción de la imagen sino que aspira también a erguirse en un verdadero discurso sobre la imagen. Los ejercicios descriptivos en cierto modo conectan con el artificio que los manieristas italianos conciben como inganno, dado que aspiran a seducir a los lectores en una especie de trampantojo verbal o visivo». De esta manera y frente a la concepción paisajística moderna, en la poesía gongorina aflora un cierto «alejandrinismo poético» donde «no hay cesura alguna entre lo humano y la Naturaleza». La plausible relación del paisaje marino de las Soledades con las «vistas acuáticas de Filóstrato desde el campo de la inventio pueden servir como vía de acceso al concepto paisajístico de Góngora». La identificación con el concepto reiterado de los «lienzos de Flandes» y la puesta en contacto con la reacción academicista de Jáuregui «nos da una información precisa acerca de cuáles podían ser las aspiraciones de un poeta tan poco dado a lo convencional. En el campo pictórico, un artista que pone su genio en la elaboración de naturalezas muertas y variados paisajes, los dos géneros más humildes según la estimativa del siglo xvII, jamás podrá alcanzar el «justo título de maestro [...]. Probablemente, según la estimación de los detractores del nuevo estilo el vínculo de las Soledades con la pintura de paisaje podría llevar aparejada una noción afín: la identificación del poeta como artista menor» (2014: 375-395). 
A modo de conclusión, P. Ruiz subraya que «la poética de las ruinas apunta su trascendencia en una riqueza mayor que la descripción formalista de sus loci y emblemas» (p. 56). Una riqueza que se compendia en tres supuestos:

1) El descubrimiento de la alteridad en un modo diferenciado a los del héroe épico o la amada neo-petrarquista. «Surge la conciencia de la intemperie, no tanto en el espacio como en el tiempo, pues el sujeto se siente inerme ante su inexorable transcurrir y sus devastadores consecuencias»».

2) El sujeto y su escenario se insertan «en el doble juego de historia y memoria, de la dimensión colectiva incrementada con el paso de los siglos y de la dimensión personal, con el recuerdo del pasado y la inminencia e inevitabilidad de un final, el propio».

3) El retorno desde el objeto (la ruina ausente) y el sujeto (el contemplador). Una verdadera «actitud de re-flexión», ya que es su propio devenir «lo que el poeta contempla al dirigir la mirada a las ruinas». Además, de imposibilidad de recuperar lo que el tiempo ha destruido «acentúa la conciencia de la pérdida, abriendo de la lírica a perspectivas inexploradas hasta el momento».

«Si la introspección petrarquista - concluye - abría la primera parte de la modernidad con el asentamiento de una conciencia subjetiva, la poética de las ruinas, con su dominante imagen de precariedad, desplaza esa conciencia a la tesitura de su inutilidad para sentar una subjetividad igualmente inestable, propia de una modernidad más plena. Mientras algunos poetas intentan mantenerse en la validez de la pura interpelación ecfrástica, propia de lo crepuscular, las mentes más lúcidas asumirán su tránsito por los campos de soledad» ${ }^{84}$ (p. 58).

\footnotetext{
${ }^{84}$ La explicación ahí ensayada conectaría con el eruditísmo trazado que hace $\mathrm{Cl}$. Conforti sobre «Spazio, tempo e rovine nel giardino del Rinascimento». Comienza afirmando que «il giardino formale, nei termini in cui si configurò in epoca rinascimentale e barocca unisce a una perspicua connotazione contemplativa la rovina architettonica, sia essa autentica o artificiale. La cultura rinascimentale, che più di ogni altra si è nutrita del lascito memorabile del mondo antico, ricercandone le tracce visible, misurandole, disegnandole, emulando apassionatamente in ogni forma di arte e di pensiero, esclude le vestigie classiche corrose dal tempo dal recinto perfetto del giardino, che pure è disseminato di simulari delle antiche divinità greco-romana». Inspirado en la tradición de los orti romanos de Lúculo y Mecenas a Adriano, conocidos a través de fuentes literarias, es el libro Ix del De Re Aedificatoria de L. B. Alberti el que traza el modelo de jardín donde incluso caben inscripciones epigráficas, obeliscos, templos y grutas pero no ruinas. Un abismo separa el hortus conclusus medieval del jardín secular moderno: «Si noti — subraya tras una rica ejemplificación histórica- che in nessuna di queste rappresentazioni compaiono rovine di monumenti. La metafora edenica che investe il giardino rinascimentale è tra le cause dell' esclusione delle rovine architettoniche dalla scena del giardino moderno». «Fino ad ora ci siamo concentrati sul forte nesso che il giardino intrattiene con la categoria dello Spazio [...].
} 
A. R. Posada centra su intervención en «El Coloso de Rodas: un paradigma autónomo en la poesía de las ruinas del Siglo de Oro». Partiendo de Horacio y de su expresión de la perennidad de la palabra poética, opone la caducidad de los monumentos físicos: «Poco o nada se conserva de las bellas ciudades y de las majestuosas obras de arte que otrora decoraron los templos de los itinerarios seguidos por Pausanias en su periegesis». Tampoco nada de las maravillas de la Antigüedad, a excepción de las pirámides listadas por Herodoto o por Plinio el Viejo. El humanismo descubre el poder insaciable de Cronos «a la par que una advertencia del implacable castigo divino a la soberbia humana» (p. 179). «La ruina se convierte así en un espejo de muerte, un memento mori que inspira en la contemplación de la estatua derribada el fatal destino del hombre ${ }^{85}$. La escultura colosal inclinada por el tiempo, imagen final del ídolo pagano reducido a escombros, encierra la naturaleza escatológica de lo material. Suponen, en definitiva, estas composiciones movidas por el lamento de la gloria efímera, la nostalgia de la época clásica y el eco tortuoso del $u b i$ sunt, un recordatorio funesto de que nuestro destino es el polvo».

Tras unas reflexiones genéricas sobre el tópico superbi colli en el Renacimiento y el Barroco, potenciando la significación de la ruina como fórmula expresiva de que «nada es eterno ni estable», pues «el tiempo frustra cualquier ansía de perennidad», y otras acerca de la estructura binaria victa-victric, entre el monumento colosal y la variedad terrena (vestigia), anotando de pasada las leyendas de Babel y de la Atlántida, se centra, recordando, mi referencia al compendio de Ravisio Textor, en el paradigma autónomo de los

Secondo un topos intrinseco alla metafora delle rovine romane decifrate come Vanitas Vanitatum o Memento Mori, il monito morale è enfatizzato proprio dal contesto tra la desolata devastazione in atto e la passiata grandeza di cui le rovine, malgrado tutto, rimangono impressionanti vestigia [...]. Il giardino formale intende conservare un' immagine remota, intatta e intangibile del tempo [...]. Dal giardino rinascimentale viene esclusa anche la dimensione circolare del tempo, quella che le stagioni riannodano anualmente» (Kardeka, 2013: 109-112 y 115-116, con el nutridísimo aparato de notas).

${ }^{85}$ Estas conclusiones se sitúan en la línea explicativa de P. Spedicato cuando afirma que «uno sguardo summario della poesia delle rovine permette di notare non solo la persistenza attraverso i secoli, ma di riconoscerne una evoluzione, una sua componente dinamica» (1986: 81). En su artículo para el Dizionario delle letteratura italiana, R. Negri llega a distinguir como campos autónomos el de las ruinas y el de las tumbas. Si estas representan la definitiva decadencia de los destinos individuales, aquellas muestran la inminencia de una pérdida definitiva de la memoria colectiva y de las civilizaciones («Poesia delle rovine», III, p. 258). En cualquier caso la «modernidad plena» solo se alcanzará en los siglos XVIII y XIX (en el trayecto que va de un Piranesi a Ruskin, o de la modernidad a una tardomodernidad) como determino y especificó más adelante, en anuencia a lo que P. Ruiz (pp. 52-53) ha apuntado respecto al paralelismo de las ruinas y el jardín «como la contraposición entre la armonía y el equilibrio clásico, emblematizados por este último y el protorromantico sacudimiento provocado por la contemplación de las ruinas». 
miracula y en el soneto al coloso de Rodas de Cáncer y Velasco (pp. 191-192). «La peculiaridad del paradigma autónomo de los titanes esculpidos estriba en que la desproporción soberbia del monte es sustituida por el tamaño colosal de la estatua de Rodas, pero sin que por ello se vea afectada la significación moral de la poesía de las ruinas»y. Puede leerse el poema de Cáncer y Velasco como una advertencia y ejemplo moral contra la pompa de la Corte. En palabras de Lara Garrido, en tales versos "el pasado renace en traducción a un signo moral de aplicación presente, amonestando contra las glorias mundanas". Dicho lo cual, la caída del coloso de Rodas «representa la máxima expresión del contemptus mundi y la vanitas. Nada es duradero ni lo suficientemente estable como para no sucumbir a las inclemencias del tiempo; ni siquiera el poder terrenal de los emperadores y reyes, pues la muerte todo lo iguala» ${ }^{86}$ (pp. 191-192).

La pieza de Cáncer y Velasco «es fruto quizás de un entorno academicista». La hipótesis se afianza con el señalamiento explícito de otro poema homónimo compuesto por José Pérez de Montoro A la ruina del Coloso de Rodas, escrito con motivo del asunto «que se le repartió al autor en una Academia» («Yaces, oh maravilla de los siglos...»), que a continuación se reproduce en su integridad (pp. 192-193). Fundamentándose en los principios clásicos del estudio de E. Orozco Díaz sobre la fragilidad de las ruinas como recuerdo del deshacerse del cuerpo humano volviendo a su primitivo origen, su «elocuente» paralelo con «la vejez y la muerte» y «la dolorosa y real visión plástica del derrumbamiento de su Imperio [el español]», va desgranando los principios compositivos del poema de Pérez de Montoro (maravilla-ruina, sublime-abatido, respeto-lástima, años-instante, prodigio-escollo, eterno-olvido, etc.). Y así «acentúa el poeta el eco de la propia caída, además de contemplar en ellas «un cementerio, un sepulcro... hasta convertir la poesía en un epitafio de lo muerto», estando asimismo consagradas «al testimonio elegiaco de la caída del colosal Estado español». Suma, en fin, que hace del coloso de Rodas «espejo de la vanidad de vanidades, de que la fama alcanzada por el arte es igualmente efímera». Ni su altura ni su tamaño, «nada pueden hacer para

\footnotetext{
${ }^{86}$ Como indiqué en páginas a las que con honestidad exquisita remite este artículo, «el poeta ha querido denotar la universalidad de las ruinas con la resonancia universal de su localización en los continentes (Asia, Europa, África) al igual que sugiere el poder avasallador el tiempo en la destrucción de los miracula y sus recuerdos». Estos elementos monumentales de una «polis universal», eran, a la vez, el «compendio imaginario de las grandes realizaciones del hombre sobre la tierra» (Ramírez, 1981: 57-89). En la andadura barroca los miracula se convierten a veces en paradigmas autónomos, como en el soneto al que aludía yo de Gerónimo de Cáncer y Velasco, A las ruinas del Coloso de Rodas (Lara Garrido, 1999b: 262-263).
} 
impedir su derrota frente a la potestad del tiempo inclemente según la voluntad del propio destino» ${ }^{87}$ (pp. 193-195).

En «Estas de admiración reliquias dignas: Variaciones de un tópico en el ciclo A las ruinas de Roma del conde de Villamediana», F. Gherardi comienza recordando (con Setti y, sobre todo De Caprio) cómo se debe a la cultura del Humanismo «el haber puesto a punto un modelo formal sobre las ruinas romanas (modelo de gran permeabilidad en su función de monumenta $\mathrm{y}$, a la vez, de instrumento ético-cognoscitivo)». Roma reúne en sí al trasunto de un pretérito positivo —el mito imperial — los connotadores de sacralidad (muy pronto sus ruinas serán calificadas de «reliquias»), lo que dota a sus restos de un pasado modélico y de una posibilidad de futuro que desemboca en la idea misma de la resurrectio Romae (frente a la extinción o pérdida de prestigio de las otras ciudades clásicas).

La contribución de Villamediana al motivo de las ruinas es mínima y monocorde, reduciéndose a los tres sonetos dedicados a las de Roma, y distribuidos entre los líricos («Las pompas con que Roma vio superba...» y «De los aplausos que miró triunfales...») y los fúnebres («Estas de admiración reliquias dignas...»), suponiéndose que su composición remonta a los años de estancia italiana del conde (1610-1611 hasta 1615) ${ }^{88}$. Solo cabe una lectura integrada de los tres sonetos para, a través del funcionamiento de las imágenes comunes, desentrañar los significados profundos que el autor quiso vehicular. Los tres presentan variaciones del tema polarizados entre los efectos del tiempo en la materia (que es trasunto de la vanidad humana) y el poder eternizador de la fama adquirida por medio del valor y virtud personales. El tiempo es protagonista directo u oblicuo (en la perífrasis «padre de los siglos»)

${ }^{87}$ Es de lamentar que no se hayan tenido en cuenta para este poema de academia recogido en las Obras posthumas los exhaustivos encuadres que sobre el autor ha llevado a término A. Bègue, al que simplemente se hace una mínima referencia genérica en nota (p. 194). Véase su monumental monografía (2019) en especial el apartado sobre «Les trois foction rhétoriques: lamentatio, consolatio, et laudatio funebris» del capítulo consagrado a la poesía fúnebre (I, 164192), el de sus actividades como poeta académico vistas a través de los mecanismos de escritura poética (III, especialmente 761-786), y la incardinación del poema en el conjunto de procedimientos de estilo (III, 671-760); también para las formas métricas en las Obras posthumas y la posible datación de las composiciones (Iv, 1075-1102). Por mi parte solo indicaré la frecuencia con que Pérez de Montoro emplea la identificación fúnebre del cadáver y las ruinas (véase el romance octosílabo «De nuestra fatal ruina...», incluido también en las Obras póstumas, de entre los poemas fúnebres dedicados a la muerte de Felipe iv, o el soneto escrito en la misma ocasión «Busco entre los despojos funerales» con su título latino Quaero ossa Philippi patris et non invenio). En este mismo sentido argumenta sobre Francisco de la Torre y Sevil, centrándose en la relación entre las ruinas y la iconografía religiosa, V. Vider (1991-1993: 75-95).

${ }^{88}$ Gherardi aduce inconcretos estímulos como la curiosidad del visitante y la familiaridad de Tassis por los bienes anticuarios. Creo de mayor interés la propuesta hecha por F. de Armas $(1982: 61,79)$ sobre la mediación de los frescos de Rafael en el Vaticano. 
en un sistema de variaciones restringido: su victoria sobre todas las cosas que son sus «trofeos», la antonomasia histórica (ejemplificada en César y Pompeyo) y el referente arquitectónico-monumental. Para este (con su código de labores que opone los correlatos del fausto y las cívicas glorias a los más metafóricos de la destrucción, la muerte y el olvido), parejas series antitéticas elaboran tres ordenamientos alegóricos (el arquitectónico, el político y el moral), aunque el tercer poema adopta la conocida estructura deíctica combinada con el hipérbaton, cuya fuerza de apertura aprovecha el desarrollo modélico de un género como el epitafio fúnebre. Conexión que consiente subrayar otro aspecto: el de la naturaleza visionaria de la esperanza. De esta forma «a efectos del éxito aleccionador del poema el destinatario tiene que, primero, establecer una relación analógica, y luego identificarse con la metonímica ciudad, sufriendo en su propia piel el paisaje, la trasformación de sí mismo, de lo humano a lo no humano, de cuerpo vivo a polvo, hierba y piedra» (pp. 143-148).

Tras considerar remontándose al Convivio dantesco de Roma como mito de la ciudad divina, el estudio termina «Ruinas adentro» ${ }^{89}$, con el perspectivismo

\footnotetext{
${ }^{89}$ La elección de Villamediana no resulta muy provechosa por el escaso rendimiento y la monotonía temática que su lírica muestra respecto al motivo de las ruinas. Y es lástima por la agudeza, variedad y precisión con que F. Gherardi analiza los sonetos de Villamediana. Pero compárese, sin más, su reiterado diseño con la variabilidad intencionada con que un Cristóbal de Mesa, trata el motivo de las ruinas en su Valle de lágrimas y diversas rimas, Madrid, Juan de la Cuesta, 1607. Dos de sus sonetos están dedicados a Roma. El primero, con fórmula de enumeración simple, para mostrar el poderío del tiempo, buscando alivio y consuelo en el transcurrir para el sujeto locutor que pondría fin a su mal (posiblemente amatorio): «Teatro, capitolio, coliseo / colunas, arcos, mármoles, medallas, estatuas, obeliscos y murallas / do vencieron las obras al deseo; / templos, carros triunfales, gran trofeo / de reinos, de vitorias, de batallas, / colosos, epitafios y antiguallas / de los sepulcros que desiertos veo. / Pirámides, pinturas, termas, baños, / reliquias y ruinas de la pompa / del edificio de la antigua Roma, / si puede tanto el curso de los años, / podrá ser que también el tiempo rompa / mi mal, pues toda cosa acaba y doma» (f. 103r); el segundo acoge la variedad destructiva que aqueja a «la soberana y triunfante Roma» para trazar un consecuente moral genérico (igual sucede con la «gloria» mundanal): «Si las ínclitas glorias peregrinas / de la soberana ya triunfante Roma, / por las naciones que su imperio doma, / egipcias, griegas, bárbaras, latinas; / si las estatuas y antiguallas dinas / de inmortal fama en todo noble idioma, / derriba el tiempo y vence la carcoma, / dejándoles blasón de antiguas rüinas, / si de colunas y arcos y trofeos / queda en lugar del claro eterno nombre / frágil mármol y bronce por memoria, / máquinas falsas son varios deseos, / de breve humano honor de alto renombre, / pues que del mundo así pasa la gloria» (f. 103v). Por el contrario una verdadera laudatio urbis conduce la deploratio - a la vez encomiatio - de Mérida como «Roma de las Españas»: «Soberbios arcos ínclitas ruinas / de Mérida, ya Roma en las Españas, / mármoles a quien dieron las montañas / para enseñar historias peregrinas, / fábricas donde ya gentes latinas, / mostrando gran poder y altas hazañas / sacaron a la tierra las entrañas / en piedras y metales de las minas. / Si estatuas, si murallas, si colunas, / dan lustre a nuestra noble Extremadura, / como reliquias de su antigua gloria, / constante al bien y al mal de ambas fortunas, / su gente en esta y en la edad futura / por armas ganará inmortal memoria» (f. 145r); y en un cuarto soneto es «la alta antigua Troya», ahora sí modelo conformador del imperio del eros: «Viénese al suelo la alta antigua Troya, / va tinto en sangre el caudaloso Xanto / y
} 
vence en agua que le aumenta el llanto / al soberbio Danubio y la Damoya. / Por tan grande ciudad queda una hoya, / rastro y ruina de edificio tanto, / causa horror, causa miedo, causa espanto / ver en ceniza y polvo una tal joya. / Destruye amor por solo un rostro griego / de Neptuno la fábrica y Apolo, / arma la tierra, altera el mar profundo. / Su fuego tiene imperio en aire y fuego, / da guerra y paz, da muerte y vida él solo, / y trastorna la máquina del mundo» (ff. 61r-v). El más original de la serie es el soneto en que Mesa funde desde la realidad astral y la universalidad del poderío de la Parca, el inexorable cambio metamórfico de la «florida primavera» en «caro invierno», es decir el sometimiento humano a una ley inexorable: «Todo al fin tiene todo alto imperio, / lo acaba el tiempo, el tiempo lo arruina, / el sol de su mayor rayo declina / buscando con su luz nuevo hemisferio. / Ya tiene libertad, ya cautiverio, / nación fiera o gentil, griega o latina, / ya cual o cual la Parca cruel destina / a túmulo, a sepulcro o cimenterio. / Si un sublime edificio viene al suelo / y el curso largo de la edad ligera / vence lo antiguo, vende lo moderno, / si nada acá permite eterno el cielo, / también nuestra florida primavera / los años mudarán en cano invierno» (f. 73r). O con la serie no menos interesante debida poco después a Salas Barbadillo, quien comienza evocando paradigmáticamente las ruinas romanas (concentrando desde el motivante del inicio sangriento de la urbs a su consagración como espejo de la civitas Dei) A Roma: «Ciudad que aun no nacida te bañaste / en sangre de uno de tus fundadores, / prodigio en que a tus pueblos inferiores / los imperios sangrientos amenazaste. / No me admiro de ver que sujetaste / las provincias más nobles y mayores, / si en ti como instrumentos vencedores / los premios de las armas vinculaste. / Cíñente siete montes, cuya alteza / ya tus torres están predominando, / donde unas piedras de otras llevan palma. / Fuiste de los idólatras cabeza, / y agora de los fieles, mejorando / de imperio, cuanto excede al cuerpo el alma». Siguen luego las ruinas cartaginesas, que explanan el castigo de la soberbia pasada junto a la admiratio de quien las contempla ahora y deduce un consecuente moralizante y admonitorio: A las ruinas de Cartago: «Piedras que aunque nacistes inferiores / en la tierra tan altas os pusistes, / que de vuestro elemento fuera os vistes / al fuego y a sus lumbres superiores. / Desconocidas tanto, ser mejores / que las estrellas casi os persuadistes, / y émulas suyas en la alteza fuistes, / ya que imposible fue en los resplandores. / Aquí os veréis, ¡oh piedras veneradas / de mí!, que más me admiro que os contemplo, / en quien descubro singular doctrina. / Útiles todo aquello que humilladas, / lo que fue admiración sirve de ejemplo, / no sin admiración de vuestra rüina». A estas se agrega luego el motivo de las míticas ruinas troyanas (cenizas ya que infama el viento y objeto de una reflexión de ética histórica sobre la ofensa y la venganza): A los muros de Troya: «Muros de Troya en quien el fuego hambriento / que Paris encendió cebó su llama, / con que dejó en las lenguas de la fama / tanta queja del mal como escarmiento, / cuyas cenizas al osado viento / cuando más las sublima las infama, / porque con vil desprecio las derrama / sin hacer de su daño sentimiento. / ¿La culpa que hubo en dos, con tanta vida / se había de pagar? Venganza inmensa / que ya de crüeldad título alcanza. / Porque a no ser la ofensa conocida, / aun se creyera ser mayor la ofensa, / por el grave rigor de la venganza» (f. 10r). Pero Salas alcanza a descubrir desde el mismo motivante de vanitas y desengaño un espacio nuevo a la reflexión meditativa. En cierto sentido viene a ampliar el campo gnoseológico de las ruinas, al hacer extensible lo predicado de la obra humana, de las ciudades y edificios, a la naturaleza misma. No ya el agente destructor que enseña su omnímodo poder en frágiles arquitecturas $\mathrm{y}$ vestigios del pasado cuanto vértice de una batalla sempiterna y emblema inigualable de la mutabilidad y la inconstancia naturales (esto es, del poderío irrefrenable del tiempo): A la caída de un monte: «Mortalidad confiesa, aunque tan vano, / este monte en pedazos dividido, / que al que vientos armados ha vencido / ya le puede ultrajar el más liviano. / Artífice fue dél la sabia mano / del tiempo, que también le ha destruido, / tanto por esta acción ennoblecido / cuanto en su formación se miró ufano. / Esparcido en las nubes por el viento / apenas lo que fue se determina, / y en tal nudo a los ojos se hace extraño / que a los desvanecidos escarmientos / pudiera persuadir su fatal rüina, / si cupiera en tal vicio el desengaño» (f. 29r). 
sintetizador del «estatuto de múltiple significación de las ruinas romanas en tanto signo debido al hecho de que ellas son al mismo tiempo el lugar de la presencia y de la ausencia, o también el lugar en donde se genera una tercera realidad plástica, al tiempo que testimonian una continuidad del presente con el pasado; su ambigüedad estaba, por tanto, en el hecho de que son símbolos de un declinar manifiesto, pero también de una grandeza ostentada; valen tanto en cuanto victimas del tiempo como vencedores de él. Y precisamente en esta ambivalencia constitucional estriba la permeabilidad del símbolo». El texto concluye con unas interesantes pero libres disquisiciones sobre «la dimensión subjetiva -emotiva e intra-psíquica - del yo cogido en plena contemplación del paisaje ruinoso». Un compensado efecto de racionalidad e irracionalidad: «por un lado, la ruina libera, rescata y hace aflorar un deseo de inmortalidad que la parte racional desconoce o no quiere reconocer; por otro lado, la propia imagen censoria (por repulsiva) separa dicha pulsión precisamente por su capacidad de materializar plásticamente la noción del castigo» ${ }^{90}$. El poema, en sí mismo, fruto de una negociación, de una transacción entre la conciencia objetiva y la conciencia subjetiva; una «relación fetichista» que «frente al disgusto por la grandeza perdida» opone «el placer, el empañamiento de ternura por la posibilidad — un autoengaño — de detenerlo todo, ahora y todavía, en el presente» (Gherardi, 2019: 154-155) ${ }^{91}$.

${ }^{90} \mathrm{El}$ ejercicio de transferencia entre el sujeto y las ruinas, en traza distendida de la troquelación gongorina, da lugar a este autorretrato de la vejez del conde don Bernardino de Rebolledo. Una fijación biotanatográfica y semihumorística con algo de arcimboldesca: «El invencible curso de los años, / los excesos en ellos repetidos, / peligrosos desastres padecidos / en los climas del orbe más extraños. / Anticipando inevitables daños, / notifican potencias y sentidos, / los objetos no bien reconocidos / manifiestan costosos desengaños. / Las manos y los pies, sin ejercicio: / aun repararse del dolor no emprenden; / vacilando, los dientes certifican / la ruina que amenaza al edificio. / Solo los pensamientos se defienden, / y los cabellos que los significan (1660, f. 619).

${ }^{91}$ Estas metaconclusiones, que carecen, en realidad de sustancia textual, merecen contrastarse con lo que, en pleno Barroco, elaboran los poetas que se desprenden de la hermenéutica nominativa de las grandes ruinas o de las ruinas menores para configurar un discurso de contraposición retorica entre ruinas y naturaleza. Véanse las liras de Baltasar López de Gurrea $A$ las ruinas de un edificio: «Despojo de los días / que experimentas trágicos sucesos / y en tristes agonías / eres el obelisco de tus huesos / y del tiempo a la instancia / cadáver eres ya de tu arrogancia. // Del arte desperdicio, / tumba de tu soberbio ser altivo, / ¿dónde estás edificio / muerto a la pompa, al desengaño vivo, / que en suerte peregrina / eres el epitafio de tu ruina? // ¡Oh cuantas en ti admiro / verdades que el espíritu ilumina / en íntimo retiro / a advertir falsedades que la adulan, / leyendo desengaños / en el papel confuso de los años! // El que yugo pasado / escollo feo incumbe a tu tormento, / de luces coronado, / dorado capitel ilustró al viento, / y hoy en suertes crüeles / el suelo huellan ya tus capiteles. // Lo que hoy zarzas espesas / con túmulo indecente te circuyen / (que otras flores traviesas / tan onerosos pasos cuerdos huyen) / tan otras se miraron / que de augustos brocados se adornaron. // Aquella tumba oscura / donde tanto edificio se aposenta, / y en negra sepultura / su antigua vanidad triste lamenta, / 
Antes de concluir la parte directamente consagrada a «la poesía de ruinas en el Siglo de Oro» mi revisión del volumen vario y rico en apuntamientos, dictamino que contiene aportes muy sólidos y cargados de sugerencias: un volumen, en definitiva, esencial para el estudio de esa parcela tan rica y variada del motivo. Pero no quisiera dejar pasar la ocasión de subrayar también la desigualdad —o si se quiere el desequilibrio - que configura el sumando de los aportes ${ }^{22}$. Por eso mismo, aunque ya lo he ido notando a lo largo de mis comentarios, quisiera cerrar esta parte de mi discurso echando de menos la alusión siquiera a alguno de entre los poemas que yo considero esenciales en el Barroco español. Espero que los lectores que hayan tenido la paciencia de llegar hasta aquí, me agradecerán que les transmita el que para mí es uno de los mejores - si no el mejor- de los poemas escritos a las ruinas en el Siglo de Oro español. Sin más comentario, merecemos disfrutar de un poema señero de Antonio Enríquez Gómez, que fulge con luz propia en ese libro esencial del Barroco que es las Academias morales de las Musas (1642: ff. 148-152) ${ }^{93}$ :

con soberbia jactancia / de altivo dueño fue real estancia. // Allí, donde yaciente / aquel trozo de fábrica termina, / y en despojo indecente / una ruina confunde a otra ruina, / si antes real teatro, / tosco de fieras es anfiteatro. // Allí donde se advierte / aquel mármol en bronce laberinto, / adórnale la suerte / de sutiles labores de Corinto, / siendo su jaspe fino / pasmosa suspensión al peregrino. // Entre aquellos fragmentos / do el vistoso lagarto logra aprisco, / y con sus pasos lentos / pisa la falda inculta de aquel risco, / entre desaire bello / deidad humana destrenzó el cabello. // Aplauso fue ruidoso / este largo silencio que suspende / donde ahora pavoroso / solo del silbo aéreo el eco ofende, / y en áspera mudanza / todo es horror y todo destemplanza. // Alcázar cuyo nombre / infausto logra término a tu pompa, / porque el tiempo le asombre / a bronce, a quien el tiempo audaz no rompa / de su pasada gloria, / esta inscripción le queda a su memoria: // «Despojo, desperdicio, / escollo, sepultura, anfiteatro, / cadáver, edificio, / tumba, obelisco, ruina, mármol, teatro, / labores de Corinto, / todo yace en confuso laberinto».

92 Pasamos con él de una ladera («la imagen de las ruinas de la admonición íntima») a otra («la dolorosa y real visión plástica del descubrimiento de un Imperio») en el discurrir del motivo tal como analizó con maestría E. Orozco (1942: 130). En un poeta no hace mucho tiempo rescatado selectivamente, G. Enríquez de Arana, la serie de composiciones a la ruina de la monarquía española, se adensa de materia histórica. Basta como muestra este soneto $A$ los presentes lamentos desta monarquia sobre su ruina: «Llore España al presente sin consuelo / de verse por su error tan hecha esclava, / que para quedar bien necesitaba / de un César, de un Bernardo o de un Marcelo. / Enfermó de cobarde y sin recelo / dio un vaivén aun peor que el de la Cava, / pues cuando más en zancos se juzgaba / vino el Ilión de su Babel al suelo. / Despreció de su amante el mucho halago / con que la pretendió, porque no ignore / lo que le debe en contra de su estrago. / Más pues no se excusó a que la devore / de tal suerte el rigor viendo a Cartago, / sin consuelo al presente España llore» (1996: 234).

93 Una condensación admonitoria sobre la intensidad metafórica del ser humano y la naturaleza figura igualmente en el mismo volumen de Enríquez Gómez. La transformación del hombre con el paso del tiempo, con el sucederse de las estaciones, en polvo, tierra y condensado mármol, traza un círculo ineluctable donde triunfa la Naturaleza: «Ves el monte mayor sujeto al rayo / pues hace burla de tu tiempo breve / si una vez se le cae la roma nieve / pero en tus canas una vez perdida / no vuelve nunca con la propia vida: / ¿Quién sabe si los mármoles oyeron / quién sabe si hombres fueron? / A tierra van, y puede fácilmente / ser edificio lo que 


\section{Canción a la ruina de un Imperio}

Esta campaña, que desierta apenas la yerba a manchas sale vergonzosa y este monte, que en rústicas almenas babilónica torre es lastimosa, mano, sí, poderosa, desvaneció su pompa y hermosura. ¡Oh vana arquitectura, fábrica errante de soberbia mano, obelisco tirano,

Babel que las estrellas conquistando torbellino de rayos fue bajando, vapor que apenas sube cuando le expande voladora nube!

Tus altos y soberbios capiteles, garzotas que adornaban las regiones, cometas son visibles y crüeles, y en mármoles partidos torreones. ¿Adónde los varones están, que con las armas en la mano defendían tu muro soberano?

¿Dónde está tu grandeza, tu meromixto imperio, tu nobleza, tus doctos senadores, tus príncipes, jüeces y señores, cuyo valor fecundo puso yugo a los términos del mundo?

Sangrienta espada de coral teñida segó, como a las mieses el verano, corvo acero tu sangre, y divididas el campo matizó del Oceano; taló como tirano el riguroso y bárbaro enemigo, el que segundo en ti fuera castigo; no te dejó esperanza de volver a tu antigua confianza, muriendo tu deseo en las mismas cenizas del trofeo.

fue viviente, / y no fuera de daño que la suerte / el polvo convirtiera en mármol fuerte, / sirviéramos de ejemplo / un templo que vivió de un muerto templo» (1612: f. 27). Es una dirección contrapuesta $-\mathrm{y}$ a la vez complementaria - de la que como motivo de vanitas admonitoria conduce el «grave afán», a «los umbrales secos de la muerte», como escribe Gabriel Fernández de Rozas en su soneto A un ramo de un árbol tan cargado de fruta que estaba desgajándose del tronco (1662: f. 4v). 
Así acaba y recibe

justo premio quien muere como vive [...].

En los golfos del orbe la bonanza, tormentoso del mar se volvió horrible viaje, cuando en rumbos de alianza fue la calma tormenta más terrible. ¿Adónde está sensible tu místico laurel, si su memoria en anales diáfanos, la historia canta de tu rüina, trágica en todo, en parte peregrina, brevemente anegada y en abismos de olvido sepultada, rayo que el viento abrasa y en breve luz relámpago que pasa?

Tus huestes militares, tus legiones, de quien temblaba el húmedo tridente, sepultados en bárbaras prisiones ni aun cadáveres son en occidente; tu hermoso y claro oriente, hidra vil del ocaso, pálido eterno te será fracaso, que olímpicos deseos en campos de Senar mueren trofeos; mejor te hubiera sido ser en potencia el reino del olvido, que no bajan de un vuelo del bélico dosel del quinto cielo.

Sepultado en las délficas centellas aun no mereció ser tu estado, cuando Nembrot quisiste ser de las estrellas, humildes con soberbia derribando; pieza a pieza girando se llevó tu hermosura el rayo, cuya dórica escultura (imagen adornada) estatua de Nabuco fue adorada, siendo entre polvo luego, arista vana en la región del fuego, $\mathrm{y}$ con delirio humano blanco crüel de tiro soberano.

¿Adónde están los que juntó tesoros la ambición del estado consumido? ¿Adónde están los que lloró decoros el político, habiéndolos perdido? 
Tu consejo temido, tu nombre idolatrado, tu materia ignorada en el estado y tu soberbio solio ¿adónde se ha jurado Capitolio?

¿Es sueño tu rüina?

No, que la mano del autor divina, los ojos del ejemplo

abrió sobre la imagen de tu templo; y a la luz del castigo el estrago se vio del enemigo.

¿Adónde está el blasón, dónde la diestra

del furioso esplendor, lucero quinto, bélica entre los ánimos palestra de vital corazón ardor sucinto?

Pero si en vano pinto la potencia triunfante y el valor de tu brazo fulminante, llore en fino alabastro tu rüina el sol y gima dentro el austro a la tórrida zona, cuanta ejemplar se entronizó corona, pues tus rayos dorados primero fueron sombra que eclipsados.

$* * *$

\section{III}

En un ensayo general que ya ha sido citado alguna otra vez en este estudio, se enfrentaba S. Marchán Fiz a lo que denomina «la ruina encontrada y la artificial». Ejemplificando con las ruinas de la Abadía Rievaulx en Yorkshire ${ }^{94}$,

94 Para los jardines barrocos, véanse los colectivos de J. Maderuelo (1998) y J. E. Laplana Gil (2000). Como antecedente esencial y en transición próxima a los últimos jardines barrocos (porque las obras se iniciaron en 1695) hay que citar el maravilloso conjunto Schömbrunn en Viena cuyas obras se aceleraron a comienzos del xviII bajo la dirección de J. E. Fisher von Erlach y finalizaron hacia 1780 por obra del arquitecto N. Pacassi. Se trata de un jardín simbólico en la medida en que tanto su repartición (que corrió inicialmente bajo las pautas del jardinero francés J. Pretat) como el palacio en sí constituyen una lectura político-mitológica inspirada en parte por Versalles. Al pie de la colina se encuentra, conformando ese valor simbólico del jardín paisajista, el conjunto de ruinas romanas —originalmente conocidas como ruinas de Cartago, en expresión de la victoria de Roma, expresión mítico-alegorizante de la casa de los Habsburgo y representante del antiguo Sacro Imperio Romano-, y la fuente del obelisco 
que se integró en un jardín paisajístico hacia 1750, y con el encargo hecho poco después a L. Brown de tratar las ruinas de la Roa di Abbei «con sentimiento de poeta y con ojos de pintor», indica que «a partir de ahora, tanto los pintores como los poetas y arquitectos rebasan las fronteras de la arqueología para admirarlas como parte integrante de un paisaje [...]. La encantadora acuarela de la abadía Kirkstal (1802) de Th. Gistin, podía ser tomada como el exponente de la serie en donde la ruina, medieval o clásica, es interpretada con los atributos de un motivo pintoresco, confundida con los accidentes del paisaje, en sintonía con las obras de un H. Repton y otros arquitectos coetáneos $[\ldots] »$. De mayor acogida disfrutaron aun las ruinas artificiales ${ }^{95}$ construidas. Empiezan a erigirse en Inglaterra durante el primer cuarto de siglo y tienen en S. Miller su más prolífico constructor, destacando las de H. Park (1747-1748) o las de la Abadía Lacock (1754-1755). La ruina artificial se afirma como un género ideal para quien persigue la simbiosis entre naturaleza y arquitectura» (pp. 7-8). La vivencia de las ruinas es singularmente ambivalente, y por ello será tambien el siglo ilustrado el que les conceda su plena autonomía estética,

(levantada hacia 1775), rematada en una esfera dorada, representación del sol y expresión simbólica de las aspiraciones de los Habsburgo a mantener el poder absoluto de la monarquía (Kurdiovsky, 2005).

${ }^{95}$ El jardín paisajista nace y se desarrolla en Inglaterra y sus diseñadores utilizaron como modelos los paisajes clasicistas de pintores barrocos como Ch. de Lorena y N. Poussin, además de la experiencia directa del viaje europeo conocido como el Gran Tour, un periplo que finalizaba en Italia. Quedaba como modélica la serie de villas de Palladio y templos romanos que surgieron en las mansiones situadas alrededor de Londres. Entre los eximios creadores del jardín paisajista se encuentran A. Pope, el jardinero Ch. Bridgeman, W. Kent y, sobre todo, L. Brown. Son jardines-palacetes que aprovechan el territorio natural con sus accidentes y sitúan en el conjunto, al modo de los pintores modelo, ruinas arquitectónicas y efectismos de simulación telúrica, además de templetes y monumentos diversos (A. von Buttlar, 1993, y los capítulos iniciales de Ch. Quest-Ritson, 2003).

En su esencial reflexión de 1780 On Modern Gaderning. Anecdotes of painting in England, N. Walpole traza una breve historia del «arte de la jardinería» remontándose como prototipo al jardín del Edén, y reflexiona, entre otros, sobre los jardines colgantes de Babilonia y los que denomina «la villa toscana»: «En un periodo en que la arquitectura exhibía toda su grandeza, su pureza y su gusto, cuando se erigió el anfiteatro de Vespasiano, el templo de la Paz, el foro de Trajano, las termas de Domiciano y la villa de Adriano, cuyas ruinas y vestigios aun suscitan nuestro asombro y nuestra curiosidad» pasa a detenerse por extenso en los jardines ingleses opuestos a «los jardines simétricos y antinaturales». Indica que «los franceses han adoptado en los últimos años nuestro estilo de jardines, pero dispuestos a mostrarse fundamentalmente agradecidos a rivales más remotos, nos niegan la mitad del mérito, o más bien le originalidad de la invención». «Así, sin emplear otra cosa que los colores de la naturaleza, y haciendo uso de los aspectos más favorables, los hombres vieron surgir ante sus ojos una nueva creación». Termina aludiendo a las modernas creaciones como la del castillo de Wentworth que «había hecho del bosque, el agua, las colinas, las perspectivas y los edificios un compendio de naturaleza pintoresca, perfeccionada por la sobriedad del arte. Una época así va a exigir un historiador mejor» (Walpole, 2005: 9-11, 13-15, 38-39 y 64-66). 
dando lugar a las teoría de lo pintoresco o de la sensibilidad, derivando hacia el sentimentalismo del pleno XVIII (en poetas como Mallet, Pope o Wharton, en Inglaterra, el alemán H. von Kleist o Diderot y B. de Saint Pierre en Francia) donde las ruinas se bastan a sí mismas «y la recuperación o incluso la mera invocación de su arquitectura originaria podrían contribuir a que perdiera sus encantos. Las ruinas hechizan por sus propias imperfecciones, cautivan más que el monumento acabado, en ellas se antepone lo fragmentario a lo integrado. En una palabra, son asumidas desde una belleza que no poseían en sus orígenes» (Marchán Fiz, 1985: 8-11).

Roma vuelve a ser el axis de un proceso de spectaculum fortunae en las «solitudini inmensi» de Alfieri. Un espectáculo que podrían sintetizar la realidad de la misteriosa «fiebre romana» en las novelas de Hawthorne y de James, junto al análisis demoledor con que E. Gibbon historió la ruina y decadencia como un proceso dramáticamente inesquivable. Montesquieu relacionará las ruinas con una decadencia de la que acusa al ascetismo cristiano, frente al armonismo de Chateaubriand que canta la armonía de los santos eremitas: «Sacrés débris des monuments chrétiens, vous ne rappelez point, comme tant d'autres ruines, du sang, des injustices et des violences! Vous ne racontez qu'une histoire paisible, on tout au plus les souffrances mystérieuses du Fils de l'Homme» (L. Cellerino, en De Caprio, 1983 : 99-101). El mismo Cellerino ha recordado los datos esenciales para la conformación de las nuevas ruinas, que darán ocasión a miles de versos donde no deja de estar presente la tradición clásica y renacentista-barroca ${ }^{96}$. En 1748 se descubren Pompeya y

\footnotetext{
${ }^{96}$ En el apartado que dedica a «La ruina encontrada y la artificial», S. Marchán Fiz (1985) explica el por qué las ruinas se interpretan en la pintura siguiendo las pautas de los jardines artificiales, del paisaje al que se incorporan como elemento pintoresco, «enfatizando ya las partes ruinosas cubiertas de vegetación [...] incorporando incluso personajes que parecen mostrar que el lado ruinoso es lo gustado a la moda y digno de ser visitado». Lo ejemplifica con la serie continuada de pintores ingleses como J. I. Richards, M. A. Rocker o R. Wilson, y con una obra en particular, la acuarela de la Abadía Kirkstal (1802) de Th. Girtin, «exponente de la serie en donde la ruina medieval o clásica es interpretada con los atributos de un motivo pintoresco, confundida con los accidentes del paisaje». Lo decisivo en estas series pictóricas «es borrar las diferencias, dotarlas de una composición y una presencia tales que parezcan estar conformadas realmente por la acción del tiempo o el poder indomable de la naturaleza [...]. La ruina, de nuevo revelaba una connivencia anticlásica, lo cual aclara que, aun no descartando la arquitectura clásica, se siente más atraída por la gótica o seudogótica» (pp. 7-8). Reflexiones interesantes sobre la poética de las ruinas desde Schelling y sus Ideas para una Filosofía de la naturaleza (1797), el romanticismo tardío de Viollet de Dac y Ruskin, entre otros, figuran en sus pp. 11-14. Con más amplitud y riqueza de datos y perspectivas, véanse, además, A. Snapp (2011) y el colectivo de 2009 Des temps qui se regardent...

P. Redondo y S. Salgado (2017) han retomado elucidar la dialéctica más compleja sobre «El construir, el habitar y la ruina». Partiendo de la teoría del conocimiento de E. Kant afirman que «el afán de construir traspasa las fronteras técnicas, prácticas y estéticas, introduciéndose en órdenes de actividad de alcance epistemológico y existencial. Los partidarios del
} 
Herculano, en 1751 Palmira y en 1755 Paestum. Esta última fecha es doblemente significativa por el catastrófico terremoto de Lisboa «che introduce il monito della distruzione subitanea, catastrofica, inmotivata, occasione di crisi profonda nelle filosofía settecentesca. Pompei ed Ercolano uniscono la catastrofe naturale alla sopravvivenza intatta dei segni, degli uomini del passato. Tornamo altri miti, il sogno limite di Atlantide [...]. Poi, c'è, evento senza paragone, il ritrovamento di Troia, una città di cui non si era certi che fosse esistita. E via via nell'Ottocento, Atena, Sparta, Olimpia, le valle di Tempe e cosí via. Senza contare le scoperte orientali et egizie» (p. 104).

En el volumen considerado, A. Mariño Espuelas realiza un parcial itinerario «Tras los pasos de Chateaubriand en Pompeya: el espíritu del Romanticismo» (pp. 229-237). Después de trazar un rapidísimo bosquejo del interés «tanto arquitectónico como literario» por las ruinas desde el Renacimiento hasta

constructivismo epistemológico enfatizan la importancia de lo construido, lo puesto con pretensiones de validez universal por el sujeto». Partiendo de la Crítica de la razón pura, analizan cómo «la relación entre lo dado y lo construido puede sobrepasar los márgenes de la teoría del conocimiento»; y se detienen en la filosofía de Descartes hasta llegar a Hegel, quien concibe «la arquitectura como la primera de las artes y la define como una modulación de la naturaleza bajo las determinaciones de simetría y armonía». Pero eso que Simmel consideraba que «era la más sublime de las victorias del espíritu sobre la naturaleza», no alcanza una eternización: «Del mismo modo que lo vivo muere, lo construido se derrumba [...]. Toda obra, algo abierto por definición y en algún sentido vivo al estar en desarrollo, finalmente se dispersa y desvaloriza. Por ello, a la hora de interpretar la metáfora de la construcción no queda más, alternativa que aludir a la ruina. Si dirigimos a esta una mirada ontológica, inmediatamente la relacionamos con la muerte». A la tesis de Simmel agregan la apostilla de Ortega y Gasset de que «algo es una ruina cuando queda de ello solo al esfuerzo vital necesario para que la muerte perpetúe su gesto destructor. En las ruinas quien propiamente vive y pervive es la muerte». «Por tanto prosiguen-, a la hora de interpretar la metáfora de la construcción no queda más remedio que aludir a la ruina. Si dirigimos a esta una mirada ontológica, inmediatamente la relacionaremos con la muerte y veremos que ambas son para la vida y la construcción, limites absolutos e imposibilidades respectivamente. En cambio, si la sometemos a una visión estética y nos fijamos ante todo en las ruinas arquitectónicas - por ser las que manifiestan con mayor nitidez el desequilibrio entre materia y espíritu - hallaremos todavía una posibilidad, porque veremos operar en ellas las mismas fuerzas que están presentes en la naturaleza: erosión, intemperie, hundimiento, crecimiento incontrolado de la vegetación, etc. Existen dos fuerzas o principios vitales enfrentados: la voluntad del hombre que erigió la construcción y la fuerza mecánica de la naturaleza que la hizo caer. Este enfrentamiento tiene como resultado la ruina, un desequilibrio traducido en el triunfo de la acción natural sobre la obra del espíritu». Tras recurrir de nuevo a Simmel recogen la tesis de Heidegger en su famosa conferencia «Construir, habitar, pensar»: «La metáfora del construir desvela la estancia como acción. Quizá en la tesis de Heidegger no se encuentra tanto este rasgo dinámico, pues él hace hincapié en aspectos como residir, obtener una sede, la salvación y el cuidado [...]. La expresión en construcción apunta a un hacer todavía en marcha, o en obra a lo inacabado que aún no ha dado con su destino. Este resulta insondable en el caso del hombre, no por desconocido sino por hallarse en permanente construcción y avisado de ruina» (pp. 63-72). 
Quevedo, afirma de entrada que «el Prerromanticismo y el Romanticismo entroncaron con esta visión negativa y moral de las ruinas, sin olvidar el entusiasmo arqueológico por todo tipo de ruinas» (p. 230). Chateaubriand, es un síntoma expresivo de hasta qué punto planearon las letras europeas del romanticismo en torno a los efectos del Gran Tour como moda de la etapa anterior. Pero si en sí mismo el vizconde de Chateaubriand fue un escritor viajero (baste recordar su Viaje a América y el Itinerario de París a Jerusalén), el estudio se centra en el menos importante de sus libros de viajes, «una obra de circunstancias organizada en función de las notas recogidas en su diario (de 1803 y 1804) enviadas a la sociedad que se reunía en el salón de Madame de Beaumont y en función de las cartas dirigidas desde Italia a sus intimos amigos Joubert y Fontanes». Nombrado Sécretaire de la Légation à Rome, Chateaubriand desarrolla una indiscreta labor de encuentros con el Papa Pío VII y el rey de Cerdeña Carlo Emmanuele, que no dejaron de crearle serios inconvenientes y su degradación posterior a tareas administrativas menores. En Roma, en octubre de 1803, fallece su amante Madame de Beaumont, y esto motivará su estancia de siete meses en Italia (las visitas a las ruinas, el Vesubio y Herculano y Pompeya se realizarán en enero y parte de febrero de 1804) «Esa Italia de las ruinas, los epitafios y los sepulcros le venía muy bien desde el punto de vista anímico a Chateaubriand. Él era también por aquel entonces un imperio caído. Una Italia que no tiene nada que ver con la Italia bulliciosa y vivaz que encontraremos en Sthendal o en George Sand» (p. 232) ${ }^{97}$.

Según A. Mariño, «Chateaubriand aporta la idea nueva de que el cristianismo es la única religión que ha podido establecerse en esa tierra italiana acribillada de ruinas. Habla de la gran soledad de los campos romanos, del Tíber que fluye por riberas abandonadas llevándolo a la idea de la muerte y de la vanidad de las cosas mundanas [...]. A partir de la muerte de Pauline de

\footnotetext{
97 Aunque el motivo de las ruinas y su poética abierta, con matrices modélicas y motivos en continuo reciclaje de un topos, «tra Sette e Ottocento la substruttura della rovina no è disponibile né al pensiero né alla poesía senza il contrasto sensibile tra la sopravvivenza e la scomparsa della vita, tra le costruzioni umane e la continuità naturale [...]. Ma questo può diventare un spettacolo filosofico di tale profondità e pregnanza da esser interiorizzato da un entero secolo como matrice in cui si modella il raporto intellettuale ed emotivo con il passato, con la antichità -romana e poi ellenica» (Cellerino, 2013: 101). Este artículo contiene los textos esenciales sobre ruinas desde Les jardins (1782) de J. Delille y las reflexiones de J. J. Rousseau o B. Constant hasta el artículo de Diderot en la Encyclopédie: «C'è la rovina per distruzione, per catástrofe naturale, per l'opera lenta e silenziosa del tempo». El terremoto de Lisboa y las excavaciones de Pompeya y Herculano introducen con fuerza renovada los motivos sepulcrales, en un «rovinismo [...] distinto e sostanzialmente nuovo e di tradizione europea moderna» (pp. 107110). Una precisa contextualización de todo ello se encontrará en el apartado que dedica C. García Merino a «La arqueología clásica» en la sección que analiza el Romanticismo del colectivo de 2005 El legado clásico... (pp. 469-561) y, sobre todo, en el magistral estudio de M. Papini (2011).
} 
Beaumont los paisajes italianos son para Chateaubriand siempre oscuros, nocturnos con imágenes de vacío, de abismo, de soledad [...]. En ningún caso ese Viaje a Italia puede servir como guía de viaje, pues es, sobre todo, un bello canto de tristeza» (pp. 232-233).

Es en el viaje a Nápoles cuando el libro y la escritura se transforman. Gran conocedor de los clásicos latinos (de Cicerón a Horacio) y modernos (un Torquato Tasso traído a colación en diversos momentos), Chateaubriand pasa por instantes evocadores de las grandes figuras de la Antigüedad Clásica, desde Aníbal y Escipión el Africano a diversos emperadores «y no pierde oportunidad de cantar la grandeza de la República y el Imperio romanos». Luego, rumbo a Nápoles, la crónica de su ascenso al Vesubio y las ciudadesruinas («un magasin d'antiques») centrando su descripción en Pompeya, el lugar donde la vida se ha conservado en todo su tráfago cotidiano y donde muestra gran interés por las pinturas murales que nos dan a conocer por obra y gracia del Vesubio «cómo era la pintura grecoromana, conocida solo hasta entonces por los mosaicos helenísticos» (p. 235)98. En un tono «aséptico», Chateaubriand crítica la forma en que se están llevando a cabo las excavaciones, cuando sería mucho mejor que el amontonamiento en el Museo de Portici conservarlo todo in situ: «Ne serait-ce pas là le plus merveilleux Musée de la terre? Une ville romaine conservée toute entière, comme si ses habitans venaient d'en sortir un quart d'heure auparavant». Se aprendería más, así, en una Pompeya conservada «que leyendo —en traducción de A. Mariño— todas las obras que nos ha legado la Antigüedad [...]. Lo que se hace hoy me parece funesto: arrancadas de sus lugares naturales, las curiosidades más raras se entierran en gabinetes en los que no se relacionan con los objetos que las rodeaban» (p. 236).

Aunque por su «escaso proceso de elaboración», el Voyage en Italie no pasa de ser una obra de circunstancias, en él también «emerge la belleza de la prosa de Chateaubriand que nos atrapa y nos fascina, salpicada de reflexiones melancólicas ante las ruinas que descubre teñidas de la inconfundible poesía de este insuperable maestro del Romanticismo» (p. 237) ${ }^{99}$.

98 G. P. Guzzo (1993), y para el cambio de percepción que se produce del legado clásico tras la revolución francesa, el estudio denso de J. Signes y B. Antón, «Revolucionarios y románticos» del citado colectivo Antiquae lectiones (AA. VV., 2005a: 563-583).

${ }^{99}$ Compárese esta aventurada conclusión con el apartado «Poesía e verità delle rovine: Gray, Foscolo, Leopardi», del ensayo de P. Spedicato (1986: 84-89). Las meditaciones de este estudioso trazan un marco inmejorable que apunta ya a los versos de Holderlin y las reflexiones de Heidegger sobre la función de la «memoria-pirámide-tumba», así como a las meditaciones de M. Foucault o J. Starobinski, concentradas desde Leopardi en una apertura hacia lectura donde la monumentalidad «che si manifesta per frammenti, residui e ombre mostra heideggeriamnamente i resti di ciò che dura, nel seno di ciò che rimane o resta della verità annunziata dalla poesia e dall'arte» (pp. 89-94). Véase además, por su elenco textual, R. Michea (1935-1936). 
En el enlace de los siglos XVIII y XIX, cuando se esboza la construcción geopolítica de la actual Europa, surge, pues «un fascinant retour vers l'antique». Un acelerado cuadro de valoraciones y apropiaciones arqueológicas influenciadas, primero, por las teorías de Winckelmann, y por el obligado ejercicio de interés testimonial que genera el auge viajero del Gran Tour, que tiene en Italia su foco irradiador y punto terminal. Signo de distinción cultural indiscutible y lugar de aprovisionamiento de coleccionistas que tienen en Inglaterra su esencial punto de arranque con los nombres de R. Payne Knight, Ch. Townley o W. Hamilton, que por sus posiciones ligadas a la Universidad y a la política ejercerán una fascinación irreprimible en el conjunto de Europa. Comenzando por Francia, que ejercerá una disputa hegemónica marcada en buena medida por los éxitos napoleónicos y su afán de coleccionismo irreprimible de los signos del poder imperial. Una historia fascinante de rivalidad que va desde Roma al Partenón y que no terminará más que en los grandes tratados de arqueología, y en la defensa italiana de su patrimonio monumental» $»^{100}$.

La historia de las ruinas y el particular sentido de su poética después de estas fechas no corresponde al trazado que, en paralelo al volumen coordinado por A. Sánchez Jiménez y D. Crivellari, me he propuesto trazar como comentario, en parte, como reflexión incitada por las muchas ideas que en la serie de contribuciones se agavillan con mayor o menor fortuna. A Schnapp, al conducir los resultados de un volumen señero sobre el tema, los rotula «Ruines, permanence et impermanence: un essai de conclusion». En este doble recorrido (el original y el de sus propios comentarios) no me queda sino asentir a algunos de sus predicados. Se trata de contribuciones —otras más- que «s'emploient à parcourir dans la tradition littéraire comme dans l'héritage monumental, les voies par lesquelles le monde occidental a cherché à trouver un fragile équilibre entre permanence et impermanence, entre mémoire et oubli». Una historia siempre parcial pero que traza la elíptica mimetizadora que da continuidad al discurso poético, desde la clasicidad romana a nuestros días, que hace de una panoplia de nombres y de actitudes el sema que

${ }^{100}$ Los fascinantes avatares de esta historia están pormenorizados en el brillante ensayo de J. Boukeur (en K. Kaderka, 2013: 141-149). Para W. Benjamin, epicentro de tantas teorizaciones contemporáneas, véase el ya citado ensayo de S. Forero Mendoza (2002), especialmente, pp. 157-160. Sus reflexiones al respecto están recogidas en Benjamin (2003). Queda fuera de mi consideración el análisis particular de A. Russo "“El penoso edificio de tus realidades": Dionisio Ridruejo, un poeta entre ruinas» (Sánchez Jiménez-Crivellari, 2019: 239-262), un detalladísimo y bien documentado análisis, cuya bibliografía particular descompensaría mi intento de visión panorámica. Creo de más interés recomendar vivamente el volumen de ensayo general y antología crítica debido a Martos Pérez (2008), que contiene sugerencias y análisis que desbordan con mucho su título. También, como muestra transversal, la rica documentación acopiada por J. Cortines (2010); contando además con panoramas críticos como los de A. Vauchez-A. Giardini (2000) y S. Lacroix (2007). 
reconstruye y reinstaura, siempre renovándose, los ingredientes de una poética histórica. Marcada también por el entrelazamiento y la dialéctica de lo que $\mathrm{J}$. Svenbro contempló como un esencial conflicto de la tradición poética ya en la Grecia clásica, remontándose a la VII Pítica de Píndaro: el mármol y la palabra, el desafio y la derrota de los monumenta frente al poder del tiempo. Lo que todavía Diderot colocará como el centro propulsor de la poética en su crítica a H. Robert, y que desde Kant a W. Benjamin y a S. Dagerman no cejará de repetirse en discursos siempre idénticos y siempre — paradójicamente- renovados ${ }^{101}$.

\section{BIBLIOGRAFÍA}

AA. VV. (1991): El Siglo de Oro de la pintura española, Nerea, Madrid. (2005a): «Antiquae lectiones»: El legado clásico desde la Antigüedad hasta la Revolucion francesa, Cátedra, Madrid.

(2005b): L'imaginaire des ruines, Université du Québec, Montreal. (2007): Atene e la Magna Grecia dell'età arcaica all'Ellenismo, Istituto per la Storia e 1'Archeologia della Magna Grecia, Nápoles. (2009): Ruines, traces, empreintes, INHA, París.

Alonso, D. (1974): Vida y obra de Medrano, I, en Obras completas, III, Gredos, Madrid.

ÁlVAREZ HernÁNDEZ, A. (1982-1983): «La silva Roma antigua y moderna y la lectura quevediana de Propercio (Eleg. Iv, 1)», Caput Anguli, 5, pp. 35-45. (1989): «Fuentes y originalidad en un soneto de Quevedo consagrado a Roma, sepultada en sí misma», Canente, 6, pp. 15-27.

ÁlVAREZ Y SÁENZ DE BuRUAGA, J. (1949): «Las ruinas de Emérita y de Itálica a través de Nebrija y Rodrigo Caro», Revista de Estudios Extremeños, III-IV, pp. 564-579.

ANDRÉS, R. (1994): Tiempo y caída. Temas de la poesía barroca española, I, Quaderns Crema, Barcelona.

ArACIL, A. y F. CHECA CREMADES (1981): «Mirabilia Romae. Una arqueología renacentista», Revista de Arqueología, II, 5, pp. 38-44.

101 Baste señalar a A. Schanapp (en Kaderka, 2013: 199 y 203-206), J. Svenbro (1976), con particular detención en las Píticas, pero también en las Olímpicas pindáricas; y S. Dagerman (1980), que recoge como signo y símbolo de las ruinas modernas la reflexión de Hyppolite sobre las de Hamburgo: «Si l'on aime les records, si l'on veut devenir expert en ruines, si l'on veut voir non pas une ville de ruines mais una paysage des ruines, plus désolé q'un desert, plus sauvage qu'une montagne et aussi fantastique qu'une rêve angoisse: Hamburgo». 
Arguijo, J. de (2004): Poesía, Fundación José Manuel Lara, Sevilla. Edición de G. Garrote Bernal y V. Cristóbal López.

ARMAS, F. A. de (1982): «The Four Elements: Key to an Interpretation of Villamediana's Sonnets», Hispanic Journal, 4-1, pp. 61-79.

ÁvilA, A. (1988): «La imagen de Roma en la pintura hispánica del Renacimiento», Boletín del Museo e Instituto Camón Aznar, xxxIv, pp. 19-71.

BACZYŃSKA, B. (1986): «Dos epitafios a Roma sepultada en sus ruinas. Un epigrama polaco de Nicolay Sep Szarzyński y un soneto español de Francisco de Quevedo», Scriptura, 11, pp. 31-42.

BalbuenA, B. de (1624): El Bernardo o victoria de Roncesvalles, Diego Flamenco, Madrid.

(2017): El Bernardo o victoria de Roncesvalles, I-II, Ars Poetica, Asturias. Ed. crítica de M. Zulaica López.

BALVÁs BARONA, A. (1627): El poeta castellano, Juan Rueda, Valladolid.

BARTHES, R. (1967): Ensayos críticos, Seix Barral, Barcelona.

BÈGuE, A. (2010): La poésie espagnole de la fin du XVIIe siècle: José Pérez de Montoro (1627-1694), membre d'un Parnasso oublié, I-IV, Editions Universitaires Europeennes, Sarrebrack.

BELTRÁN, V. (2017): «De Túnez a Cartago: propaganda política y tradiciones poéticas en la época del Emperador», Boletín de la Real Academia Española, 97, pp. 45-114.

BELTRÁN FORTES, J. (2017): «Las antigüedades en los círculos artísticos y anticuarios de la Sevilla de Juan de Argujo», en AA. VV., Juan de Argujo y la Sevilla del Siglo de Oro, Universidad de Sevilla, pp. 125-145.

BENJAMIN, W. (2003): La obra de arte en la época de su reproductibilidad técnica, Ítaca, México.

BiAlostocki, J. (1973): Estilo e iconografía, Seix Barral, Barcelona.

BigLIERI, A. (2001-2002): «Ruinas romanas y poesía española», Auster, 6-7, pp. 85-111.

BlanCO, M. (2012): «Obeliscos en Arcadia. Ascendencia y fortuna de un motivo gongorino», en Góngora o la invención de una lengua, Universidad de León, pp. 427-461.

BlecuA, J. M. (1986): Poesía de la Edad de Oro, I-II, Castalia, Madrid.

BolzONI, L. (1995): La stanza della memoria: modelli letterari e iconografici nell 'età della stampa, Einaudi, Torino.

Brady Wells, M. (1974): Du Bellay: a bibliography, Grand et Cutler Ltd., Londres. 
BUCK, A. (1989): «Le fonti della tradizione», en L'eredità clasica nelle letterature neolatine, La Sapienza, Roma, pp. 41-86.

BURCKHARDT, J. (1968): La cultura del Renacimiento en Italia, Iberia, Barcelona.

BUTTLAR, A. von (1993): Jardines del clasicismo y el romanticismo. El jardín paisajista, Nerea, Madrid.

CABEllo Porras, G. (1981): «Del paradigma clásico a una apertura significacional en el motivo de las ruinas a través de la poesía de Herrera», Analecta Malacitana, IV, pp. 309-329.

CACHO CASAL, R. (2009): «The Memory of Ruins: Quevedo's Silva to Roma antigua y moderna», Renaissance Quaterly, 64, 2, pp. 1167-1203.

(2012): «Roma y las ruinas de la memoria», en La esfera del ingenio: las silvas de Quevedo y la tradición europea, Biblioteca Nueva, Madrid, pp. 185-220.

CAMPO, A. del (1957): «Problemas de la Canción a Itálica», Revista de Filología Española, XLI, pp. 47-139.

CANDElas Colodrón, M. Á. (2006): «Lope de Vega y la de Troya», Anuario Lope de Vega, 12, pp. 57-66.

CARANDINI, A. (1993): «L'ultima civiltà sepolta o del massimo oggetto desueto, secondo un'archeologo», en AA. VV., Storia di Roma. III, I luoghi e le culture, Eunaudi, Torino, pp. 11-38.

CARAVAGGI, G. (1978): «Baltasar de Escobar (Mosaico storico-letterario)», Miscellanea di Studi Ispanici, pp. 94-195.

CARO, M. (1947), La «Canción a las ruinas de Itálica» del licenciado Rodrigo Caro, Voluntad, Bogotá.

CARO, R. (1923): «Canción a las ruinas de Itálica», en P. Blanco Suárez (ed.), Poetas de los siglos XVI y XVII, Junta para la Ampliación de Estudios, Madrid, pp. 280-306.

(2000): Poesía castellana y latina e inscripciones originales, Diputación Provincial de Sevilla. Edición de J. Pascual Barea.

CARREÑO, A. (2001): "“Un cántico en disfrazado velo": las Angélicas de Barahona de Soto y Lope de Vega», en A. Cruz Casado (ed.), Luis Barahona de Soto y su época, Ayuntamiento de Lucena, pp. 41-60.

CARRILLO MORELL, D. (2019): «Los muros de la patria mía y la autorreflexión como cualidad discursiva en el Salmo XVII de Quevedo», en E. Ózmen y T. Padilla Aguilera (eds.), Theory Now, 2-1, pp. 71-85 [consulta: 3 noviembre 2020].

Cascales, F. (1989): Tablas poéticas, Clásicos Castellanos, Madrid. Edición de B. Brancaforte. 
CELlerino, L. (2013): «Or tutto intorno una ruina involve. Rovina e sublime morale nel Settecento», en K. Kaderka, Les ruines: Entre destruction et construction de l'Antiquité à nos jours, Campiano Editore, Roma, pp. 95-112.

Cervantes, M. de (1986): Novelas ejemplares, I-II, Castalia, Madrid. Edición de J. B. Avalle Arce.

CetinA, G. de (2014): Rimas, Cátedra, Madrid. Edición de J. Ponce Cárdenas.

Clementson, C. (1992): «El agua sobre la piedra (En torno a Joachin Du Bellay, más algunas versiones castellanas de L'Olive et Les Antiquités de Rome)», Glosa, 3, pp. 125-165.

Colodrero De Villalobos, M. (1629): Varias Rimas, Salvador de Cea, Córdoba.

Colonna, F. (1980 [1499]): Hypnerotomachia Poliphili. Edición de G. Pozzi y L. Ciapponi, Antenore, Padua.

CONFORTI, C. (2013): «Spazio, tempo e rovine nel giardino del Rinascimento», en K. Kaderka, Les ruines: Entre destruction et construction de l'Antiquité à nos jours, Campiano Editore, Roma, pp. 109-118.

COOPER, R. (1989): «Poetry in Ruins: The Literary context of Du Bellay's Cycles on Rome», Renaissance Studies, 3, pp. 156-166.

CoRTINes, J. (2010): Itálica famosa. Aproximación a una imagen literaria. Edición, estudio y selección de textos, Diputación Provincial de Sevilla.

CRIVELlaRI, D. (2008): Il romance spagnolo in scena. Strategie di riscrittura nel teatro di Luis Vélez de Guevara, Carocci, Roma. (2019): «Escollo armado de hiedra, o el renacimiento de unas ruinas en el teatro del Siglo de Oro», en A. Sánchez Jiménez y D. Crivellari (eds.), La poesía de ruinas en el Siglo de Oro, Visor, Madrid, pp. 197-226.

CuEnCA, L. A. de (2019): «Ruinas y poesía», Prólogo a A. Sánchez Jiménez y D. Crivellari (eds.), La poesía de ruinas en el Siglo de Oro, Visor, Madrid, pp. 11-15.

D'Amico, J. C. y A. Testino Zaphiropoulos (2012): Le mythe de Rome en Europe. Modèles et contre-modèles, Presses Universitaires, Caen.

DACOS, N. (2014): «Roma quanta fuit» o la invención del paisaje de ruinas, Acantilado, Barcelona.

DAEMRICH, I. G. (1995): «The Ruin Motif as Artistic Device in French Literature», IAAC, pp. 31-41 y 449-457.

DAngerman, S. (1980): Automne allemand, Actes Sud, Arler.

DE CAPRIO, V. (1987): Poesia e poetica delle rovine di Roma. Momenti e problemi, Istituto Nazionale di Studi Romani, Roma.

Della Fina, G. M., dir. (2009): Gli etruschi e Roma. Fasi monarchica e alto-reppublicana, Quasar, Roma. 
DEMERSON, G. (1984): «Du Bellay traducteur de lui-même», en AA. VV., Neo-Latin or vernacular in Renaissance France, Oxford University Press.

Deshoulieres, V. A. y M. VACHER, dirs. (2000): La memoire en ruines. Le modèle archeologique dans l'imaginaire moderne et contemporain, Presses Universitaires Blaise Pascal, Clermont-Ferrand.

DonetTI, D. (2013): «La Antichità greche di Giuliano da Sangallo. Erudizione e rovinismo nel Libro dei Disegni. Codice Barberiniano Latino 4424», en K. Kaderka, Les ruines: Entre destruction et construction de l'Antiquité à nos jours, Campiano Editore, Roma, pp. 85-93.

DotTI, U. (1978): Petrarca e la scoperta della coscienza moderna, Feltrinelli, Milán.

DotTi, U. (1992): La città dell'uomo. L'umanesimo da Petrarca a Montaigne, Rizzoli, Roma.

Du Bellay, J. (1984) : Oeuves poétiques VII. Autres oeuvres latines, Librairie, París. Edición de G. Demerson.

(1985): Oeuvres poétiques: poemata, Librairie, París. Edición de G. Demerson.

EGIDO, A. (1994): Cervantes y las puertas del sueño. Estudios sobre «La Galatea», "El Quijote»y «el Persiles», PPU, Barcelona.

(1996): La rosa del silencio. Estudios sobre Gracián, Alianza Editorial, Madrid.

(2004): De la mano de Artemia. Estudios sobre literatura, emblemática y mnemotécnica y arte en el Siglo de Oro, José J. de Olañeta, Palma de Mallorca.

(2018) «De La Galatea a las Ejemplares. Soledad, silencio y memoria», en Por el gusto de leer a Cervantes, Fundación José Manuel Lara, Sevilla, pp. 275-325.

ENRÍQUEZ DE ARANA, G. (1996): El cisne andaluz (Selección), Ayuntamiento de Montilla. Edición de A. Cruz Casado.

ENRÍQUeZ GÓMEZ, A. (1642): Academias morales de las Musas, Pedro de la Court, Burdeos.

ESCOBAR BORREGO, F. J. (2000): «Noticias inéditas sobre Fernando de Herrera y la Academia sevillana en el Hércules animoso de Juan de Mal Lara», Epos. Revista de Filología, XVI, pp. 133-155.

(2004): «Nuevos datos sobre libros y lecturas de Juan de Mal Lara (a propósito de la "Tabla de autores" del Hércules animoso», Criticón, 90, pp. 79-98. 
(2007): «La forja del canon épico en la Academia de Juan de Mal Lara (con unos versos desconocidos de Fernando de Herrera)», Studia Aurea, I, pp. 1-37.

(2017): «Mitología y antigüedad clásica en los círculos artísticos y eruditos: las fuentes», en AA. VV., Juan de Argujo y la Sevilla del Siglo de Oro, Universidad de Sevilla, pp. 79-101.

(2019): «Fuimus Troes, fuit Ilium o Etiam periere: ruinas y apuleyanismo en la nueva Roma de diados del siglo XVI (con Petrarca como lector de El asno de oro)», en A. Sánchez Jiménez-D. Crivellari, La poesía de ruinas en el Siglo de Oro, Madrid, Visor, pp. 101-111.

ESTELLÉS Y GONZÁLEZ, J. M. (1993): «Arqueología y forma literaria: descripciones latinas del teatro y circo saguntinos de Manuel Martí y José Miñana», en J. M. ${ }^{a}$ Maestre y J. Pascual (eds.), Humanismo y pervivencia del mundo clásico, I, Universidad de Cádiz, pp. 431-440.

ÉtIENVRE, J. P. (1979): «Libros y lecturas de Rodrigo Caro», Cuadernos bibliográficos, 38, pp. 31-106.

FABRICIO COSTA, S., dir. (2005): Entre trace(s) et signe(s): quelques aproches hermenéutiques de la ruine, Peter Lang, Berna.

FERnÁndeZ DE RoZAS, G. (1662): Noche de invierno. Conversación sin naipes en varias poesías castellanas, Francisco Nieva, Madrid.

FERnÁNDEZ GUERRA, A. (1870): «La Canción a las ruinas de Itálica, ya original, ya refundida, no es de Francisco de Rioja», Memorias de la Real Academia Española, I, Madrid, pp. 175-217.

FERNÁNDEZ MuRGA, F. (1986): «El sentimiento de las ruinas en el Renacimiento italiano», en AA. VV., Actas del II Congreso Nacional de Italianistas, Universidad de Salamanca, pp. 123-149.

Ferranti, F. (2005): L'Esprit des ruines, Éditions du Chêne, París.

FERRATÉ, J. (1968): Dinámica de la poesía, Seix Barral, Barcelona.

FERri COLL, J. M. (1995a): «El Superbi colli de Castiglione y la poesía española de ruinas en el Siglo de Oro», en AA. VV, Relaciones culturales entre España e Italia, Universidad de Alicante, pp. 53-61.

(1995b), «Las ruinas en Herrera: nuevos valores y difusión del tópico», en Las ciudades cantadas. El tema de las ruinas en la poesía española del Siglo de Oro, Universidad de Alicante, pp. 39-67.

(2010), «Miré los muros de la patria mía y la tradición poética de las ruinas», Bulletin of Hispanic Studies, LXXXVII, 5, pp. 525-544.

Forero MendozA, S. (2002): Le Temps des ruines. Le Goût des ruines et les Formes de la conscience historique à la Renaissance, Champ Vallon, Seyssel. 
(2013): «Ruines et pensé de l'Histoire. Le paradigme catastrohique de Walter Benjamin», en K. Kaderka, Les ruines: Entre destruction et construction de l'Antiquité à nos jour, Campisano Editore, Roma, pp. 151-160.

(2019): «La pintura de ruinas en los siglos XVI y XVII. La propagación de un gusto y la contribución de un imaginario compartido», en A. Sánchez Jiménez y D. Crivellari (eds.), La poesía de ruinas en el Siglo de Oro, Visor, Madrid, pp. 59-71.

FosAlBA, E. (2019): «Versión oficial de la jornada de Túnez y desvío afectivo en el soneto XXIII de Garcilaso», en A. Sánchez Jiménez-D. Crivellari (eds.), La poesía de ruinas en el Siglo de Oro, Visor, Madrid, pp. 73-99.

Foulche-Delbosc, R. (1904): «Notes sur le sonnet Superbi colli», Revue Hispanique, XI, pp. 225-243.

- (1908): «237 sonnets», Revue Hispanique, XVIII, pp. 488-618.

(1916): «Rimas del Incógnito», Revue Hispanique, XXXVII, 92, pp. 251-456.

FROMMEL, S. (2013): «Tradition religieuse contre invention à l'antique: ruines dans la peinture de la deuxième moitiè du Quattrocento», en K. Kaderka, Les ruines: Entre destruction et construction de l'Antiquité à nos jours, Campiano Editore, Roma, pp. 95-108.

FuCILLA, J. G. (1955): «Notes sur le sonnet Superbi colli (Rectificaciones y suplemento)», Boletín de la Biblioteca Menéndez Pelayo, xxxi, pp. 51-93.

(1963): «Superbi colli (Notas sobre la boga del tema en España)», en Superbi colli e altri saggi, Carocci, Roma, pp. 7-43.

GAI, M. (1985): «Buscando en Roma a Roma: semejanzas y diferencias. Análisis de un soneto de Quevedo», Dispositio, x, 27, pp. 97-126.

(1986): «El arte de imitar con ingenio: Análisis comparativo de un soneto de Quevedo», Romanic Review, 21, 2, pp. 208-228.

Gallego Morell, A. (1972): Garcilaso de la Vega y sus comentaristas, Gredos, Madrid.

GALlo, D., ed. (1986), Filippo Buonarrotti e la cultura antiquaria sotto gli ultimi Medici, Olschki, Florencia.

GARCÍA BELlidO, A. (1951): «Rodrigo Caro. Semblanza de un autor renacentista», Archivo Español de Arqueología, xxiv, pp. 5-22.

GARCÍA CASTAÑÓN, S. (2002): «La retórica de la presencia en la poesía del Siglo de Oro: observaciones sobre el uso de la deixis como fórmula de apertura poemática», Crítica hispánica, XXIV, pp. 41-58.

GARnetT, O. (2000): Stourhead. Landscape Garden, The Nationel Trust, Londres. 
GiardinA, A., dir. (1986): Roma: politica, economica, paesaggio urbano, Società romana impero tardoantico, Laterza, Roma.

GIARDINI, F. (1994): «Utilisation et description symboliques de l'espace dans les Antiquitez de Rome de Joaquin Du Bellay», en AA. VV., Du Bellay et ses sonnets, Universidad de París, pp. 19-46.

GNISCI, A. (1987): «Roma come sistema delle rovine», en V. De Caprio, Poesia e poetica delle rovine di Roma. Momenti e problemi, Istituto Nazionale di Studi Romani, Roma, pp. 9-19.

Gómez CAnseco, L. (1986): Rodrigo Caro. Un humanista en la Sevilla del seiscientos, Diputación Provincial de Sevilla.

GÓMEZ MORENO, A. (1994): «La pasión por los vetera vestigia», en España y la Italia de los humanistas. Primeros ecos, Gredos, Madrid, pp. 242-258.

Gómez SÁnchez RomAte, M. J. (1983): «El mito de Troya en las Rimas de Lope de Vega», en M. García Martín, Estado actual de los estudios sobre el Siglo de Oro, Universidad de Salamanca, pp. 453-459.

GóngORA, L. de (2019): Sonetos, Cátedra, Madrid. Edición de J. Matas Caballero.

Gonzalvez AndradA, P. (1629): Varias poesías, Matheus Pinheiro, Lisboa.

GRACIOTTI, S. (1960): «La fortuna di una elegia di Giano Vitale, o le rovine de Roma nella poesia polaca», Aevum, 34, pp. 123-185.

GRAF, A. (1923): Roma nella memoria e nelle immaginazioni del Medio Evo, Chiantatore, Turín.

GrAY, F. (1978): La poétique de Du Bellay, Nizet, París.

GuZzO, G. P. (1992): Antico e archeologia. Scienza e politica delle diverse antichità, Il Mulino, Bolonia.

Hall, H. G. (1974): «Castiglione's Superbi colli in Relations to Raphael, Petrarch, Du Bellay, Spenser, Lope de Vega and Scarron», Kentucky Romance Quartely, 21, pp. 159-181.

HuI, A. (2016): The Poetic of Ruins in Renaissance Litterature, Fordham University Press, Fordham.

JAURAlde Pou, P. (1987): «Miré los muros de la patria mía y el Heráclito cristiano», Edad de Oro, 6, pp. 165-187.

JOUKOVSKY-MiCHA, F. (1969): La gloire dans la poésie française et neolatine du XVIe siècle (des Rhetoriqueurs à Agrippa d'Aubigne), Droz, Ginebra.

JULIÁ, E. (1941): «Aportaciones bibliográficas. Un dramaturgo valenciano desconocido», Revista de Bibliografia Nacional, II, pp. 201-243.

KADERKA, K. (2013): «Les ruines de Cicerón. Temples et moeurs à la fin de la Republique romaine», en Les ruines: Entre destruction et construction de l'Antiquité à nos jours, Campiano Editore, Roma, pp. 29-43. 
KURDIOVSKY, R. (2005): The garden of Schönbrunn, Residenz Verlay, Viena. LABEIRA STRANI, J. (1987): «Un esbozo de crítica textual: ordenación, cronología y descripción de las dos primeras versiones de la Canción a las ruinas de Itálica», Canente, I, pp. 69-84.

LACROIX, S. (2007): Ce que nous disent les ruines. La fonction critique des ruines, L'Harmattan, París.

LANCIANI, R. (1990): Storia degli scavvi di Roma e notizie intorno le collezioni romane di Antichità, Edizioni Quasar, Roma.

LAPlanA GIL, J. E., ed. (2000): La cultura del Barroco. Los jardines: arquitectura, simbolismo y literatura, Instituto de Estudios Altoaragoneses, Huesca.

LARA GARRIDO, J. (1981): «Notas sobre la poética de las ruinas en el Barroco», Analecta Malacitana, Iv, pp. 385-399.

(1999a): «De Herrera al Príncipe de Esquilache. Un oxímoron de Velleius Paterculus en la poesía áurea», en Relieves poéticos del Siglo de Oro. De los textos al contexto, Universidad de Málaga, pp. 91-110.

(1999b): «El motivo de las ruinas en la poesía española del Siglo de Oro. Funciones de un paradigma nacional: Sagunto», en Relieves poéticos del Siglo de Oro. De los textos al contexto, Universidad de Málaga, pp. 251-308.

(1999c): «Entre Pasquino, Góngora y Cervantes. Texto y contextos de un soneto anónimo contestado en el Persiles», en Relieves poéticos del Siglo de Oro, Universidad de Málaga, pp. 173-217.

LAVIN, I. (1992): «Memoria e senso di sé. Sul ruolo della memoria nella teoria della psicologia dell'antichità a Giambattista Vico», en L. Bolzoni-P. Corsi (eds.), La cultura della memoria, Il Mulino, Bolonia, pp. 291-317.

LECOCQ, F. (2005): «Rome, de le ruine de Troie à le ruine de soi», en S. Fabricio Costa (dir.), Entre trace(s) et signe(s): quelques aproches hermenéutiques de la ruine, Peter Lang, Berna, pp. 69-104.

LEÓN, P. (1994): «Las ruinas de Itálica. Una estampa arqueológica de prestigio», en AA. VV., La Antigüedad como argumento. Historiografía de arqueología e historia antigua en Andalucía, Junta de Andalucía, Sevilla, pp. 29-61.

LEONARDo De ARgEnsola, B. (1974): Rimas, ed. de J. M Blecua, II, Espasa Calpe, Madrid.

LEZAMA LiMA, J. (1969): «Mitos y cansancio clásico», en La expresión americana, Alianza Editorial, Madrid.

LÓPEZ BUENO, B. (1986): «Tópica literaria y realización textual: unas notas sobre la poesía española de las ruinas en los Siglos de Oro», Revista de Filología Española, 66, pp. 59-74. 
(2000): La poética cultista de Herrera a Góngora, Alfar, Sevilla.

- (2001): «Una epístola (moral) de Fernando de Soria. Canon genérico y contexto sevillano», en AA. VV., Sevilla y la literatura. Homenaje al profesor Francisco López Estrada, Universidad de Sevilla, pp. 261-281.

(2010): «La poesía sevillana del Siglo de Oro: Generaciones y semblanzas», en AA. VV., Literatura y territorio. Hacia una geografia de la creación literaria en los Siglos de Oro, Academia Canaria de la Historia, pp. 487-512.

LÓPEZ De GuRreA, B. (1633): Clases poéticas. Divídense en histórica y fabulosa, amorosa, lírica, jocosa y piadosa, Juan de Ybar, Zaragoza.

LÓPEZ ESTRADA, F. (1974): «Relectura de la Canción a las ruinas de Itálica», en Estudios de Arte Español, I, pp. 127-154.

LÓPEZ MARTínEZ, M. I. (2009), «Antecedentes clásicos de la poética de las ruinas», en AA. VV., Teoría y análisis de los discursos literarios. Estudios en homenaje al profesor Ricardo Sánchez Sempere, Universidad de Salamanca, pp. 227-234.

MACPHAIL, E. (1986): «The Roman Tomb or the Image of the Tomb in du Bellay's Antiquitez», Bibliothèque d'Humanisme et Renaissance, 48, pp. 359-372.

MACAUlay, R. (1953): Pleasure of Ruins, Thames-Hudson, Londres. (1965): La voix des Ruines, Cercle du Bibliophile, París.

MAderuelo, J., ed. (1988): El jardín como arte. Arte y naturaleza, Diputación de Huesca.

MAIRE VIGeUR, J. Cl. (2010): L'autre Rome. Une histoire des Romains à l'époque communale (XIIe-XIVe siècle), Tallandier, París.

MAKARIUS, M. (2004): Ruines, Flammarion, París.

MANACORDA, D. (1993): «Roma. I monumento cadono in rovine», en AA. VV., Storia di Roma III, I luoghi e le culture, Einaudi, Turín, pp. 93-104.

MarChenA, J. (1820): Lecciones de Filosofía Moral y Eloquencia, I-II, Imprenta de Don Pedro Beacine, Burdeos.

MARCHÁN FIZ (1985): «La poética de las ruinas. Un capítulo casi olvidado de la historia del gusto», Fragmentos, 6, pp. 4-15.

MAZZOCCO, A. (1987): «Linee di sviluppo dell'antiquaria del Rinascimento», en V. De Caprio, Poesia e poetica delle rovine di Roma. Momenti e problemi, Istituto Nazionale di Studi Romani, Roma, pp. 53-94.

MARTEl, M. (1967): Canto tercero de la Numantina y su contexto. De la fundación de Soria y origen de sus doce linajes, Caja General de ahorros de la Provincia, Soria. 
Martinengo, A. (2009): «Los paisajes italianos de Quevedo», La Perinola, 13, pp. 263-280.

MARTOS PÉREZ, M. D. (2008): Las ruinas en la poesía española. Estudio y antología, Universidad de Málaga.

McGowan, M. M. (2000): The Vision of Rome in Late Renaissance France, Londres, Yale University Press.

MEDRANO, F. de (2005): Diversas Rimas, Fundación José Manuel Lara, Sevilla. Edición de J. Ponce Cárdenas.

Melo, F. M. de (1649): Las tres Musas del Melodino, Officina Crasbeckiana, Lisboa.

(1665): Obras métricas, Horacio Boesset y George Remeus.

MENÉNDEZ PELAYO, M. (1883): «Noticia sobre la vida y escritos de Rodrigo Caro» en R. Caro, Obras, Sociedad de Bibliófilos Andaluces, Sevilla.

MENÉNDEZ PIDAL, R. (1914): «Cartapacios literarios salmantinos del siglo XVI», Boletín de la Real Academia Española, I, pp. 298-320.

MESA, C. de (1607): Valle de lágrimas y diversas rimas, Juan de la Cuesta, Madrid.

MiCHEA, R. (1935-1936): «La poésie des ruines au XVIIe siècle et la contribution de l'Italie a la sensibilité prérromantique», Etudes italiennes, v, 2, pp. 117-132 y v, 4 pp. 337-350.

Michel, A. (1991): «Du Bellay et la poésie latine», en AA. VV., Du Bellay, Angers, 1991, pp. 623-634.

MOLINA FERnÁNDEZ, E. (2005): «Sobre el soneto Miré los muros de la patria mía y sus imágenes de muerte moral», Signos literarios, 2, pp. 47-65.

MonTESINOS, J. F. (1997 [1995]): «Barroco y gongorismo», en Entre el Renacimiento y el Barroco. Cuatro escritos inéditos, Universidad de Granada.

MorÁn TURINA, M. (2010a): "Y aquella maravillosa ciudad. Roma y los españoles», en La memoria de las piedras. Anticuarios, arqueólogos y coleccionistas de antigüedades en la España de los Austrias, Centro de Estudios Europa Hispánica, Madrid, pp. 51-107.

(2010b): «Salvar la memoria de las piedras. La conservación de las Antigüedades», en La memoria de las piedras. Anticuarios, arqueólogos y coleccionistas de antigüedades en la España de los Austrias, Centro de Estudios Europa Hispánica, Madrid, pp. 154-200.

MOREL FATIO, A. (1894): «Histoire d'un sonnet», Revue d'Histoire Littéraire de la France, I, pp. 97-102.

Moreno CASTILlo, E. (2004): «Anotaciones a la silva Roma antigua y moderna de Quevedo», La Perinola, 8, pp. 501-543. 
Mortier, R. (1974): La poétique des ruines en France. Ses origines, ses variantions de la Renaissance à Victor Hugo, Droz, Ginebra.

MoRVILlEZ, L. (2013): «Abandoner ou retourner: la peur des ruines dans l'Antiquitè tardiva», en K. Kaderka, Les ruines: Entre destruction et construction de l'Antiquité à nos jours, Campiano Editore, Roma, pp. 55-67.

MotTA SAlas, J. (1948): «La Canción a las ruinas de Itálica de Rodrigo Caro», Romanische Jarbuch, XXIX, pp. 277-290.

MuscettA, C. y D. Ponchiroli, eds. (1959): Poesía del Quattro e del Cinquecento, Einaudi, Turín.

Navarro Durán, R. (1983): Poemas inéditos de Felix Persio, Bertiso, Diputación Provincial de Sevilla.

NegRI, R. (1972): «Poesia delle rovine», en AA. VV., Dizionario della lettentura italiana, III, Einaudi, Turín, sub voce.

NIDER, V. (1991-1993): «La poetica delle rovine in una relazione di Francisco de la Torre y Sevil. Sensibilitá antiquaria e iconografía religiosa», Studi Ispanici, pp. 75-95.

(2017): «Los clásicos del Siglo de Oro: de estatuas y cortesanas en los sonetos de Quevedo sobre Friné (Polimmia, 78 y 79)», Criticón, 131, pp. 89-106.

ORLANDO, F. (1993): Gli oggetti desueti nelle immagini della letteratura. Rovine, reliquiae, rarità, robaccia, luoghi inabitati e tesoro nascosti, Einaudi, Turín.

Orlin, E. M. (2002): Temples, Religion and Politic in the Roma Republic, Brill, Boston / Leichen.

OrozCo DíAZ, E. (1947): «Ruinas y jardines. Su significación y valor en la temática del Barroco», en Temas del Barroco, Universidad de Granada, pp. 119-146.

(1960): El poema «Granada» de Agustín Collado del Hierro, Patronato de La Alhambra, Granada.

(1963): Granada en la poesía barroca, Universidad de Granada.

PAPINI, M. (2009): «Etiam periere ruinae (Lucano, Bellum civile, IX, 969). Le rovine della cultura antica», en M. Barbarena (ed.), Reletti reletti. Metamorfosi delle rovine e identità culturale, Torino, Bollati Boringhieri, pp. 89-111. Roma-Bari.

PASTOR PARDO, J. (2013): «Introduccion a la poesía de ruinas en el Barroco español», Hispanista, 79 [consulta: 30 octubre 2020]. 
(2015): «La poesía de ruinas en el primer Lope», en Especulo, 20 [consulta: 23 septiembre 2020].

PeÑAlVer, E. y M. L. LozA (2017): Juan de Argujo y la poesía del Siglo de Oro, Instituto Andaluz del Patrimonio Histórico-Universidad de Sevilla.

PÉREZ DURÁ, F. J. (1993): «Un nuevo poema épico latino en los albores del siglo XVIII: la Sanguntineida de J. M. Miñana», en J. M. Maestre y J. Pascual (eds.), Humanismo y pervivencia del mundo clásico, I, Universidad de Cádiz, pp. 775-784.

PFANDL, L. (1942): Historia de la literatura nacional española en la Edad de Oro, Gustavo Gili, Barcelona.

Ponce CÁrdenAS, J. (2013): «Sobre el paisaje anticuario: Góngora y Filóstrato», en B. Capllonch, S. Pezzini, G. Poggi y J. Ponce (eds.), La Edad del Genio: España e Italia en tiempos de Góngora, Edizioni ETS, Pisa, pp. 375-395.

PORRAS, G. de (1639): Rimas varias, Juan Bautista Moreira, Antequera.

PosADA, A. R. (2019): «El Coloso de Rodas: un paradigma autónomo en la poesía de ruinas del Siglo de Oro», en A. Sánchez Jiménez y D. Crivellari (eds.), La poesía de ruinas en el Siglo de Oro, Visor, Madrid, pp. 177-195.

PozUelo CAlero, B. (2008a): «El licenciado Francisco Pacheco y su contribución a las Anotaciones de Herrera», en P. Ruiz (ed.), Cánones críticos en la poesía del Siglo de Oro, Academia del Hispanismo, Vigo, pp. 181-192.

(2008b): «La oda a Fernando de Herrera de Francisco Pacheco: un retrato del círculo sevillano en 1573», Calíope, 14, pp. 61-93.

PRICE, R. M. (1978): «Sobre fuentes y estructuras de Miré los muros de la patria mía», en G. Sobejano (ed.), Francisco de Quevedo, Taurus, Madrid, pp. 319-325.

Profeti, M. G. (2003): «Yo vi la grande y alta jerarquía: el tema de las ruinas en Quevedo», Criticón, 87-89, pp. 709-718.

Quest-RITSON, Ch. (2003): The English Garden. A social history, Penguin Books, Londres.

QuIRÓs, P. de (1882): Poesías divinas y humanas del P. Pedro de Quirós, religioso de los clérigos menores de esta ciudad de Sevilla, Imprenta de El Orden, Sevilla.

QUIRÓS DE LOS RÍOS, J. y F. RODRÍGUEZ MARÍN, eds. (1896): Segunda parte de las «Flores de poetas ilustres de España», Imprenta E. Rasco, Sevilla.

RAIMONDI, E. (1966): «Paessaggi e rovine nella poesia di un virtuoso», en Anatomie setentesche, Nistri-Lischi, Pisa, pp. 42-47.

RAMAJO CAÑO, A. (1995): «Para la filiación literaria de un soneto de Quevedo (Miré los muros de la paria mía)», Bulletín Hispanique, 97, pp. 529-544. 
RAmalho, A. da Costa (1952): «Um epigrama en latín imitado por vários», Humanitas, IV, pp. 60-65.

(1953-1954): «Um epigrama en latín imitado por vários», Humanitas, V-VI, pp. 55-64.

(1997): «As ruínas de Roma», en Estudos sobre a época do Renascimento, Fundação Calouste Gulbenkian, Lisboa, pp. 297-317.

RAMÍREZ, J. A. (1981): Arquitectura y utopía, Universidad de Málaga.

Rebolledo, B. de (1660): Ocios, Officina Plantiniana, Amberes.

REDONDO, P. y S. SALGADO (2017): «El construir, el habitar y la ruina», en La isla de la verdad y otras metáforas en filosofía, Camus Impresiones, Guarmizo, pp. 63-72.

REY ÁlVAREZ, A. (1997): «Vida retirada y reflexión sobre la muerte en ocho sonetos de Quevedo», La Perinola, 1, pp. 189-211.

RiCO GARCÍA, J. M. (2001): La perfecta idea de la altísima poesía. Las ideas estéticas de Juan de Jáuregui, Diputación Provincial de Sevilla.

RiojA, F. de (1867): Poesías, Sociedad de Bibliófilos Españoles, Madrid. Ed. de C. A. de la Barrera.

Chiappini.

RoDríGUEZ CUADROS, E. (1993): «Sagunto en la literatura: épica, vanitas y parodia», Braçal, 11-12, pp. 231-283.

RodríguEZ DE CEBALlos, A. (1991): «Los fondos arquitectónicos de la pintura del Siglo de Oro», en AA. VV., El Siglo de Oro de la pintura española, Nerea, Madrid.

RoDrÍGUEZ MoÑINO, A. (1932): «En torno al soneto Superbi colli», Revista Crítica de Estudios Extremeños, vi, pp. 35-39.

(1976): «Hernando de Soria Galvarro (Dos poesías inéditas)», en La transmisión de la poesía española en los Siglos de Oro, Ariel, Barcelona, pp. 137-162.

RODRÍGUEZ, R. (1979): «Observaciones sobre la poesía de Quevedo desde el soneto Miré los muros de la patria mía», en Anuario de Estudios Filológicos, 2, pp. 239-249.

Rubio Árquez, M. y A. J. SÁEZ, eds. (2017): La estirpe de Pigmalión: poesía y escultura en el Siglo de Oro, Madrid, Sial.

RUIZ PÉREZ, P. (2019): «Locus fictus. La invención de las ruinas y la mirada subjetiva», en A. Sánchez Jiménez y D. Crivellary (eds.), La poesía de ruinas en el Siglo de Oro, Visor, Madrid, pp. 35-58. 
RUIZ SÁNCHEZ, M. (1999): «Las ruinas deshabitadas. Notas sobre la tradición elegiaca del tema de las ruinas en la poesía neolatina», Excerpta Philologica, 9, pp. 349-376.

(2000): «Roma antigua y moderna. Observaciones sobre la imagen properciana de la primitiva Roma y su influencia en Du Bellay, Quevedo y la poesía neolatina», Analecta Malacitana, XXIII, 1, pp. 85-114 y XXIII, 2, pp. 471-491.

(2019): «Paralelos neolatinos del soneto Superbi colli de Castiglione», AnMal Electónica, 46, pp. 3-18 [consulta: 5 agosto 2020].

SÁEZ, A. J. (2015): El ingenio del arte: la pintura en la poesía de Quevedo, Versos Libres, Madrid.

(2018): «A Curcio aventajado y parecido: en torno al Elogio al duque de Lerma y otros poemas de Quevedo», Criticón, 132, pp. 105-121.

(2019): «Amable y desierta arquitectura: las ruinas en la poesía de Quevedo», en A. Sánchez Jiménez y D. Crivellari (eds.), La poesía de ruinas en el Siglo de Oro, Visor, Madrid, pp. 157-176.

SAlas Barbadillo, A. G. (1618): Rimas castellanas, Viuda de Alonso Martín, Madrid.

SAlAZAR Y TORRES, A. de (1681): Cythara de Apolo. Varias poesías divinas y humanas, Francisco Sanz, Madrid.

Salcedo Coronel, G. (1649): Cristales de Helicona. Segunda parte de las Rimas..., Diego Díaz de la Carrera, Madrid.

SÁNCHEZ JiMÉNEZ, A. (2019): «Panorama interior: poesía de ruinas en Lope de Vega», en A. Sánchez Jiménez y D. Crivellari (eds.), La poesía de ruinas en el Siglo de Oro, Visor, Madrid, pp. 115-137.

SANCHEZ JimenEZ, A. y D. CRIVELlaRI, eds. (2019): La poesía de ruinas en el Siglo de Oro, Visor, Madrid.

SCHANAPP, A. (1993): La conquête du passé. Aux origines de l'archéologie, Librairie Générale Française, París.

SCHWARTZ, L. (2014): «Principios de la ética estoica en textos de Rioja y Quevedo», en L. Gómez Canseco, J. Montero y P. Ruiz Pérez, Aurea Poesis. Estudios para Begoña López Bueno, Universidades de Sevilla y Córdoba, pp. 299-320.

SERRALTA F. (2017): «El mito de Troya en la escritura teatral de Lope de Vega», Hipogrifo, 5, pp. 421-431.

SetTIS, S., ed. (1984-1986): Memoria dell'antico nell'arte italiana, I-III, Einaudi, Turín.

SILES, J. (1991): «De la emoción lírica de un algo a la reconstrucción histórica de un todo», Prólogo a F. Jordi Pérez i Durá y J. M. Estellés i González, 
Sagunt. Antigüedad e Ilustración, Ediciones Alfores el Magnànim, Valencia, pp. 7-17.

SIMMEL, G. (1984): «Las ruinas», en Cultura femenina y otros ensayos, Espasa Calpe, Madrid, pp. 211-219.

SKYRME R. (1982): «Buscas a Roma en Roma. Quevedo, Vitalis and Janus Pannonius», Bibliothèque d'Humanisme et Renaissance, 44, pp. 363-367.

SMITH, M. C. (1977): «Looking for Rome in Rome: Janus Vitalis and his disciples», Revue de Letterature Comparée, 51, pp. 510-527.

SNAPP, A. (2011) : «Le sentiment des ruines de l'Orient aux Lumières: continuités et transformations», en Ph. Boussignol (ed.), L'archeologie comme discipline, Seuil, París.

SobeJANO, G. (1987): «El soneto de Quevedo A Roma sepultada en sus cenizas (esencia y ascendencia)», Filología, 32, pp. 105-118.

SPEDICATO, P. (1986): «Elogio dell'uppupa: rovine della letteratura e rovine del pensiero», Modern Language Notes, 101, pp. 78-94.

STAROBINSKI, J., (1964): La invención de la libertad, Taurus, Barcelona.

SVENBRo, J. (1976): La parole et le Marbre. Aux origines de la poétique grecque, Studenlitteratur, Lundt.

SZULMAJISTER-CELNIKIER, A. (2013) : «L'expression intelinguistique des ruines et sa poétique», en K. Kaderka, Les ruines: Entre destruction et construction de l'Antiquité à nos jour, Campisano editore, Roma, pp. 181-190.

TALAVERA ESTESO, F. J. (1991): «Observaciones sobre el tema de las ruinas en algunos poetas neolatinos», Analecta Malacitana, 14, pp. 289-300.

TOBAR QUINTANAR, M. J. (2002): «Miré los muros de la patria mía y la reescritura en Quevedo», La Perinola, 6, pp. 239-262.

TORRE, F. de la (1654): Entretenimiento de las Musas en esta baraja nueva de versos [...], Juan de Ybar, Zaragoza.

TUCKER, G. H. (1985): «Sur les Elogia (1553) de Janus Vitalis et les Antiquitez de Rome de Joachim Du Bellay», Bibliothèque d'Humanisme et Renaissance, 47 , pp. 103-112.

(1986): «Le portrait de Rome chez Pannonius et Vitalis: une mise au point», Bibliothèque d'Humanisme et Renaissance, XLVIII, págs 751-756.

(1990): The Poet's Odyssey: Joachin Du Bellay and the «Antiquitez de Rome», Clarendon Press, Oxford.

(1991): «Du Bellay, Janus Vitalis et Lucain: la trame des mots dans les Antiquitez plus un songe et dans quelques ven analogues des Poemata», en AA. VV., Du Bellay, Universidad de Angers, pp. 149-160. 
(1992): «Roma rediviva. André de Resende, Du Bellay, and the continuing legacy of Janus Vitalis's Romam diptych», Bibliothèque d'Humanisme et Renaissance, pp. 731-736.

VAuCHEZ, A. (2006): Roma médievale, Laterza, Roma.

VAuCHEZ, A. y A. GiARdinA, eds. (2000): Rome, l'idée et le mythe. Du Moyen Age à nos jours, Fallard, Roma.

VegA, G. de la (2017): Poesía castellana, Akal, Madrid. Ed. de J. Jiménez Heferman e I. García Aguilar.

VEYNE, P. (1984): Cómo se escribe la historia. Foucault revoluciona la historia, Alianza Editorial, Madrid.

VRANICH, S. B. (1981): Los cantores de las ruinas en el Siglo de Oro, Esquio, Ferrol.

WALPOLE, H. (2005): El arte de los jardines modernos, Siruela, Madrid.

WARDROPPER, B. W. (1969): "The poetry of Ruins in the Golden Age», Revista Hispánica Moderna, 35, pp. 295-305.

WiLKIns, E. M. (1980): Vita del Petrarca e la formazione del «Canzoniere», Feltrinelli, Milán.

WILSON, E. M. (1936): «Sobre la Canción a las ruinas de Itálica de Rodrigo Caro», Revista de Filología Española, XXIII, pp. 379-396.

ZARCO CuEVAS, J. (1933): «Un cancionero bilingüe manuscrito en la biblioteca de El Escorial», Religión y Cultura, XxIv, pp. 406-449.

ZERNER, H. (1996): L'art de la Renaissance en France. L'invention du classicisme, Flammarion, París.

ZuCKer, P. (1968): Fascination of Decay: Ruins: Relic, Symbol, Ornament, The Gregg Press, Ridgewood (N. J.). 